\title{
Synthesis of azaindoles, diazaindoles, and advanced carbazole alkaloid intermediates via palladium-catalyzed reductive $\mathbf{N}$ - heteroannulation
}

\author{
Grissell M. Carrero-Martinez \\ West Virginia University
}

Follow this and additional works at: https://researchrepository.wvu.edu/etd

\author{
Recommended Citation \\ Carrero-Martinez, Grissell M., "Synthesis of azaindoles, diazaindoles, and advanced carbazole alkaloid \\ intermediates via palladium-catalyzed reductive N-heteroannulation" (2008). Graduate Theses, \\ Dissertations, and Problem Reports. 4360. \\ https://researchrepository.wvu.edu/etd/4360
}

This Thesis is protected by copyright and/or related rights. It has been brought to you by the The Research Repository @ WVU with permission from the rights-holder(s). You are free to use this Thesis in any way that is permitted by the copyright and related rights legislation that applies to your use. For other uses you must obtain permission from the rights-holder(s) directly, unless additional rights are indicated by a Creative Commons license in the record and/ or on the work itself. This Thesis has been accepted for inclusion in WVU Graduate Theses, Dissertations, and Problem Reports collection by an authorized administrator of The Research Repository @ WVU. For more information, please contact researchrepository@mail.wvu.edu. 


\title{
Synthesis of Azaindoles, Diazaindoles, and Advanced Carbazole Alkaloid Intermediates via Palladium-Catalyzed Reductive $N$-Heteroannulation
}

\section{Grissell M. Carrero-Martínez}

\author{
Thesis submitted to the \\ Eberly College of Arts and Sciences \\ at West Virginia University \\ in partial fulfillment of the requirements \\ for the degree of \\ Master of Science \\ in \\ Chemistry
}
Björn C. G. Söderberg, Ph.D., Chair
Kung K. Wang, Ph.D.
John H. Penn, Ph.D.

C. Eugene Bennett Department of Chemistry

\author{
Morgantown, West Virginia \\ 2008
}

Keywords: Pd-Catalyzed N-Heteroannulations, Azaindoles, Diazaindoles Copyright 2008, Grissell M. Carrero-Martínez 


\begin{abstract}
Synthesis of Azaindoles, Diazaindoles, and Advanced Carbazole Alkaloid Intermediates via Palladium-Catalyzed Reductive $N$-Heteroannulation
\end{abstract}

\author{
Grissell M. Carrero-Martínez
}

Over the years, azaindoles and diazaindoles have generated an increased interest due to their structural similarities with indoles and their potential as pharmacologically active compounds. A mild and efficient methodology has been developed for the synthesis of azaindoles and diazaindoles. This novel procedure includes a palladiumcatalyzed reductive $N$-heteroannulation as the key step. This methodology was successfully applied to the synthesis of 4-azaindole, 2-phenyl-5-azaindole, 2-phenyl-6azaindole, and 7-azaindole. In addition, this method was efficiently utilized to synthesize 2-phenyl-4,6-diazaindole and 2-phenyl-4,5-diazaindole. The reductive $\mathrm{N}$ heteroannulation was carried out in the presence of $\mathrm{Pd}(\mathrm{dba})_{2}, 1,10$-phenanthroline, and carbon monoxide (6 atm) in DMF at $120^{\circ} \mathrm{C}$.

A number of carbazole alkaloids have been synthesized and are of great interest due to the wide array of biological activity these compounds exhibit. Advanced intermediates of carbazole alkaloids were prepared utilizing a Stille coupling to afford the cyclization precursors, 2-(2-nitroarene)-2-cyclohexenones. These precursors were subjected to the palladium-catalyzed cyclization developed, smoothly affording the desired carbazolones. Utilizing this method, the cyclization precursor of an advanced carbazolone intermediate of $(+)$-Aspidospermidine was obtained in good yield. Reductive cyclizations of Stille coupling products, 2-(2-nitroarene)-2-cyclohexenones, using $\mathrm{Pd} / \mathrm{C}$ and $1 \mathrm{~atm}$ of hydrogen yielded the corresponding 1,2,3,4-tetrahydrocarbazole derivatives. 


\section{Acknowledgements}

I would like to express my gratitude to my research advisor, Dr. Björn C. G. Söderberg, for his guidance, encouragement, knowledge, and patience. I would also like to thank the members of my committee, Dr. Kung K. Wang and Dr. John H. Penn for their time and assistance. I would also like to express my appreciation to Dr. Novruz Akhmedov for all his help with the data acquisition.

I am very grateful for the help, support, and friendship of my laboratory coworkers. My special thanks go to Chris Dacko, Amy Aylor, Rachel Byerly, and Jeremiah Hubbard, their encouragement, love, and friendship made my graduate experience enjoyable and unforgettable.

I want to thank my family and friends for their love, encouragement, patience, and for always believing in me. I would like to give my special thanks to my mom, María Migdalia, my brother, Franklin, and my sister-in-law Julie because their advice and guidance made this possible. I am certain that I wouldn't be here without any of them.

The financial support of the C. Eugene Bennett Department of Chemistry at West Virginia University and the National Science Foundation is also gratefully acknowledged. 


\section{Table of Contents}

Title Page $\quad$ i

Abstract $\quad$ ii

Acknowledgements $\quad$ iii

Table of Contents $\quad$ iv

List of Schemes $\quad$ vi

List of Figures viii

List of Tables $\quad$ ix

\section{Part I}

Synthesis of Pyrrolopyridines and Pyrrolodiazines Via Palladium-Catalyzed Reductive $N$-Heteroannulation

1. Introduction 1

1.1 Pyrrolopyridines 1

1.2 Pyrrolodiazines 8

$\begin{array}{ll}1.3 \text { Reductive } N \text {-Heteroannulation } & 15\end{array}$

2. Results and Discussion 17

2.1 Synthesis of Pyrrolopyridines 17

2.2 Synthesis of Pyrrolopyrimidines 19

$\begin{array}{ll}2.3 \text { Synthesis of Pyrrolopyridazines } & 23\end{array}$

2.4 Attempted Synthesis of Pyrrolopyrazine 25

3. Conclusion 30 


\section{Part II \\ Synthesis of Carbazolones as Advanced \\ Intermediate to (+)-Aspidospermidine}

1. Introduction 32

2. Results and Discussion $\quad 37$

3. Conclusion 39

\section{Part III}

Synthesis of Advanced Intermediates of Tetrahydrocarbazole Derivatives via Palladium-Catalyzed Hydrogenation Reactions

1. Introduction 41

2. Results and Discussion 43

3. Conclusion 46

\section{Part IV}

Experimental Section

1. General Procedures $\quad 47$

2. Experimental Details 48

$\begin{array}{ll}\text { References } & 58\end{array}$

$\begin{array}{ll}\text { Appendix } & 61\end{array}$ 


\section{List of Schemes}

Scheme 1: Reissert synthesis $\quad 2$

Scheme 2: Madelung synthesis of 7-azaindole 3

Scheme 3: Bartoli cyclization 3

Scheme 4: Hemetsberger-Knittel synthesis 4

Scheme 5: Batcho-Leimgruber synthesis of immucillin analog 20

Scheme 6: Organolithium mediated synthesis of 7-azaindole derivative 5

Scheme 7: Internal and terminal alkynes in the preparation of azaindoles 6

Scheme 8: Synthesis of 4-azaindole derivative 33

Scheme 9: Suzuki coupling for the synthesis of 7-azaindole derivative 36

Scheme 10: Yamanaka's azaindole synthesis $\quad 7$

Scheme 11: Boehringer-Ingelheim azaindole synthesis 8

Scheme 12: Synthesis of 4,7-diazaindole derivative 50

Scheme 13: Synthesis of 50 via Sonogashira coupling 10

Scheme 14: One-pot synthesis of $50 \quad 10$

Scheme 15: Synthesis of 4,7-diazaindole derivative $56 \quad 10$

Scheme 16: Two-step reaction synthesis of $\mathbf{5 9} \quad 11$

Scheme 17: One-pot synthesis of $\mathbf{5 9} \quad 11$

Scheme 18: Synthesis of 4,6-diazaindole derivative $63 \quad 12$

Scheme 19: Synthesis of pyrrolo[3,2-d]pyrimidine 63

Scheme 20: Tkachenko's synthesis of $\mathbf{6 7} \quad 13$

Scheme 21: Müller's preparation of 4,6-diazaindole derivative 69

Scheme 22: Senga's synthesis of derivative 71 13

Scheme 23: Synthesis of ethyl pyrrolo[3,2-c]pyridazine-6-carboxylate 2-oxide 74 14

Scheme 24: Synthesis of 4,5-diazaindole derivative $77 \quad 14$

Scheme 25: Palladium-catalyzed $N$-heteroannulation 15

Scheme 26: Watanabe's indole synthesis $\quad 15$

Scheme 27: Cenini's indole synthesis 16

Scheme 28: Strategy for azaindole preparation 17

Scheme 29: Synthesis of 4-azaindole 1

Scheme 30: Synthesis of 7-azaindole $4 \quad 18$

Scheme 31: Synthesis of 2-phenyl-5-azaindole 89

Scheme 32: Synthesis of 2-phenyl-6-azaindole 91

Scheme 33: Synthesis of 4,6-dichloro-5-nitropyrimidine 92

Scheme 34:Synthesis of 5H-pyrrolo[3,2,-d]pyrimidine derivative 96

Scheme 35: Attempted synthesis of 6-nitro-substituted pyrimidine 22

Scheme 36: Attempted preparation of pyrimidine N-oxides 22

Scheme 37: Failed nitration of 3-chloro-6-methylpyridazine 23

Scheme 38: Pyridazine N-oxides 98-100 24

Scheme 39: Synthesis of 4,5-diazaindole derivative 105

Scheme 40: Initial attempt towards $1 H$-pyrrolo[2,3-b]quinoxaline 26

Scheme 41: Synthesis of coupling precursors 112 and 113 
Scheme 42: Attempts towards a methyl pyrazine 28

Scheme 43: Synthesis of 5-methyl-2,3-diphenylpyrazine 115

Scheme 44: Formation of carbazolone derivative 117

Scheme 45: Preparation of carbazolone 119

Scheme 46: Aubé's synthesis of (+)-Aspidospermidine 35

Scheme 47: Heathcock's synthesis of $( \pm$ )-Aspidospermidine 36

Scheme 48: Short synthesis of $( \pm)$-Aspidospermidine 37

Scheme 49: General synthetic strategy

Scheme 50: General Stille coupling strategy 38

Scheme 51: Synthesis of carbazolone precursor 142

Scheme 52: Reduction with $\mathrm{TiCl}_{3} \quad 40$

Scheme 53: Synthesis of methyl-substituted 1,2,3,4-tetrahydrocarbazoles 41

Scheme 54: Tanaka's indole synthesis of 149

Scheme 55: General reductive cyclization $\quad 42$

Scheme 56: Synthesis of advanced intermediate 152

Scheme 57: Synthesis of carbazole 155

Scheme 58: Synthesis of carbazole 161 


\section{List of Figures}

Figure 1: Structures of 4-, 5-, 6-, and 7-azaindoles 1-4 2

Figure 2: Diazaindoles 43-48 9

Figure 3: Carbazole alkaloids 33

Figure 4: ${ }^{1} \mathrm{H}$ NMR of 2-nitro-3-vinylpyridine 86

Figure 5: ${ }^{13} \mathrm{C}$ NMR of 2-nitro-3-vinylpyridine 86

Figure 6: ${ }^{1} \mathrm{H}$ NMR of 4-methoxy-5-nitro-6-styrylpyrimidine 95

Figure 7: ${ }^{13} \mathrm{C}$ NMR of 4-methoxy-5-nitro-6-styrylpyrimidine 95

Figure 8: ${ }^{1} \mathrm{H}$ NMR of 4-methoxy-6-phenyl-5H-pyrrolo[3,2-d]pyrimidine 96

Figure 9: ${ }^{13} \mathrm{C}$ NMR of 4-methoxy-6-phenyl-5H-pyrrolo[3,2-d]pyrimidine 96

Figure 10: ${ }^{1} \mathrm{H}$ NMR of 6-methyl-4-nitro-3-styrylpyridazine 1-oxide 104

Figure 11: ${ }^{13} \mathrm{C}$ NMR of 6-methyl-4-nitro-3-styrylpyridazine 1-oxide 104

Figure 12: ${ }^{1} \mathrm{H}$ NMR of 6-methyl-2-phenyl-5H-pyrrolo[3,2-c]pyridazine 105

Figure 13: ${ }^{13} \mathrm{C}$ NMR of 6-methyl-2-phenyl-5H-pyrrolo[3,2-c]pyridazine 105

Figure 14: ${ }^{1} \mathrm{H}$ NMR of 2-triflate-3-nitro-5,6-diphenylpyrazine 112

Figure 15: ${ }^{13} \mathrm{C}$ NMR of 2-triflate-3-nitro-5,6-diphenylpyrazine 112

Figure 16: ${ }^{1} \mathrm{H}$ NMR of 2-chloro-3-nitro-5,6-diphenylpyrazine 113 


\section{List of Tables}

Table 1: Coupling conditions evaluated

Table 2: Stille and Suzuki coupling attempts

Table 3: Sonogashira coupling conditions 


\section{Part I}

\section{Synthesis of Pyrrolopyridines and Pyrrolodiazines via Palladium-Catalyzed Reductive $N$-Heteroannulation}

\section{Introduction}

Naturally occurring pyrrolopyridines, or azaindoles, are relatively scarce. These indole analogs have created considerable interest as they are essential building blocks in many pharmaceutically relevant drugs. Some azaindole derivatives have shown numerous biological activities such as anthelmintic, ${ }^{1}$ non-narcotic antitussive,${ }^{2}$ antimalarial, ${ }^{3} \mathrm{HIV}-1$ inhibitory, 5- $\mathrm{HT}_{6}$ antagonist, and antagonist of gonadotropin releasing hormone, ${ }^{4}$ among others. In addition, these molecules have also found applications in coordination chemistry and material synthesis. ${ }^{5}$ Similarly, pyrrolodiazines have sparked significant interest since they are of ample value as pharmaceutical agents. Some derivatives of pyrrolodiazines have shown antitumor activity, ${ }^{6}$ potent inhibitors of purine nucleoside phosphorylase, ${ }^{7}$ antibiotic, ${ }^{8}$ citostatic, antiviral, ${ }^{9}$ antiglucoma, and anticancer activities. ${ }^{10}$

\subsection{Pyrrolopyridines}

Numerous synthetic methods have been developed for the preparation of substituted indoles, but relatively few have been used for the synthesis of azaindoles (Fig. 1). This may be due to the electron-deficient nature of the pyridine ring which alters the $\pi$-system in such a way that those methods either do not work or give poor results. ${ }^{11}$ In recent 
years, thanks to improvements made to classical indole synthesis methods and the development of the organometallic chemistry field, new routes have been developed and reported in the literature for the synthesis of azaindoles.<smiles>c1cnc2cc[nH]c2c1</smiles><smiles>c1cc2[nH]ccc2cn1</smiles>

1: $1 H$-pyrrolo[3,2-b]pyridine (4-azaindole)

2: $1 H$-pyrrolo[3,2-c]pyridine
(5-azaindole)<smiles>c1cc2cc[nH]c2cn1</smiles>

3: 1H-pyrrolo[2,3-c]pyridine (6-azaindole)<smiles>c1cnc2[nH]ccc2c1</smiles>

4: $1 H$-pyrrolo[2,3-b]pyridine (7-azaindole)

Figure 1. Structures of 4-, 5-, 6-, and 7-azaindoles 1-4

Several conditions have been used for the formation of azaindoles; among them is the Reissert synthesis. Originally used for indoles, a 2-nitropicoline and diethyl oxalate are reacted in the presence of sodium ethoxide followed by a reduction/cyclization (Scheme 1$)^{11}$ to obtain a 2 -substituted azaindole.<smiles>Cc1ccncc1[N+](=O)[O-]</smiles>

5

5<smiles>CCOC(=O)OCC</smiles><smiles>CCOC(=O)C(=O)Cc1ccncc1[N+](=O)[O-]</smiles>

$6(42 \%)$<smiles>CCOC(=O)c1cc2ncccc2[nH]1</smiles>

$7(84 \%)$

Scheme 1. Reissert synthesis

Another method which was previously used to prepare azaindoles is the Madelung synthesis. It requires a base and high temperatures for the cyclization of $o$-amidopicolines (Scheme 2). ${ }^{12}$ Some of the disadvantages of this method include: (a) the limited 
application for azaindole synthesis due to the harsh conditions, (b) the reaction is subject to variables such as quality of reagents, and purity of starting materials, among others, and (c) yields are often erratic and irreproducible. ${ }^{13}$<smiles>Cc1cccnc1NC(=O)C(C)(C)C</smiles>

8<smiles>C[Mg][Mg][Mg]</smiles><smiles>CCc1cccnc1/N=C(\O)C(C)(C)C</smiles>

9
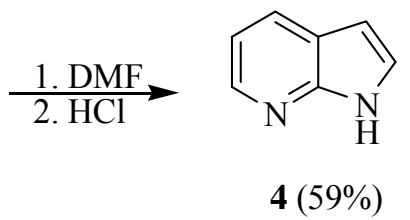

Scheme 2. Madelung synthesis of 7-azaindole

Extensively used for the synthesis of indoles, the Bartoli cyclization offers an alternate method. It was anticipated that this reaction would provide an efficient pathway to the preparation of azaindoles due to the similarities with indoles. Wang and co-workers reported syntheses of 4- and 6-azaindoles (Scheme 3) using nitropyridines and a large excess of vinyl Grignard. ${ }^{14}$ The yields were low to moderate, but comparable to the results obtained in the preparation of indoles. It was also noted that the presence of a large substituent or a halogen next to the nitro moiety gave higher yields of azaindoles.<smiles>COc1ncccc1[N+](=O)[O-]</smiles>

10<smiles>Cc1ccncc1[N+](=O)[O-]</smiles>

12<smiles>COc1nccc2cc[nH]c12</smiles>

$11(20 \%)$<smiles>Cc1ccnc2cc[nH]c12</smiles>

$13(18 \%)$

Scheme 3. Bartoli cyclization 
The first example of a Hemetsberger-Knittel synthesis of an azaindole derivative was carried out by Fresneda and co-workers in 2000. A few years later, Roy and co-workers studied the generality of this reaction for a series of substituted 5-, 6-, and 7-azaindoles. ${ }^{15}$ This method requires the conversion of a pyridine carboxaldehyde into the azidopyridine acrylate, followed by thermal cyclization (Scheme 4).

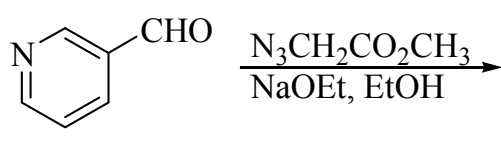

14

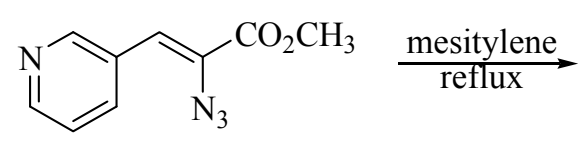

$15(56 \%)$<smiles>CC(=O)c1cc2cccnc2[nH]1</smiles>

$16(25 \%)$

Scheme 4. Hemetsberger-Knittel synthesis

Tyler and co-workers used the Batcho-Leimgruber method for the synthesis of aza-Cnucleoside immucillins 20 (Scheme 5). ${ }^{11}$ Condensation of o-nitropicoline with N,Ndimethylformamide dimethyl acetal (DMF-DMA), followed by a reductive cyclization of the enamine affords the azaindole.

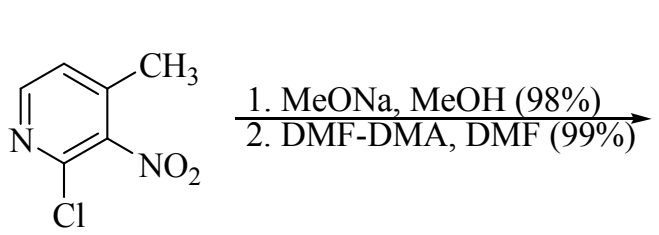

17

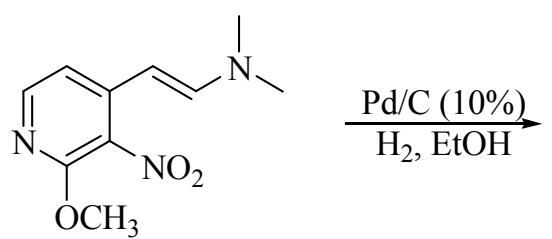

18

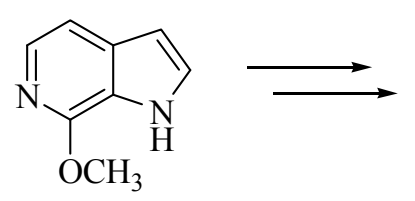

$19(89 \%)$<smiles>O=c1[nH]ccc2c(C3NC(O)C(O)C3O)c[nH]c12</smiles>

Scheme 5. Batcho-Leimgruber synthesis of immucillin analog $\mathbf{2 0}$ 
Advances in organometallic chemistry have enabled a number of novel and efficient routes for the construction of azaindoles. Organolithium and palladium catalysis has been used for the preparation of azaindoles. A new route for the synthesis of substituted 7-azaindole was reported by O'Shea and co-workers. ${ }^{16}$ The methodology involves a reaction sequence of controlled carbolithiation of the vinyl double bond, subsequent trapping of the dianion with an electrophile, followed by ring closure and dehydration (Scheme 6).

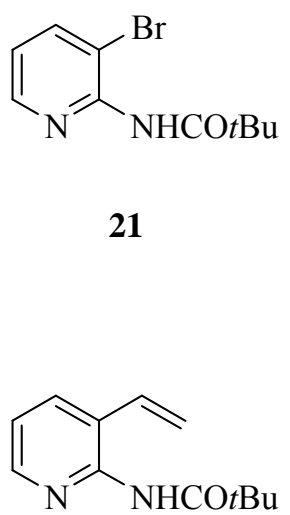

$23(85 \%)$<smiles>C=CB1OBOB(C=C)O1</smiles>
$\frac{\mathrm{Pd}\left(\mathrm{PPh}_{3}\right)_{4}, \mathrm{~K}_{2} \mathrm{CO}_{3}}{\text { DME, } \mathrm{H}_{2} \mathrm{O}, \text { reflux }}$<smiles>C=C[18CH][13CH]=CC</smiles>

22

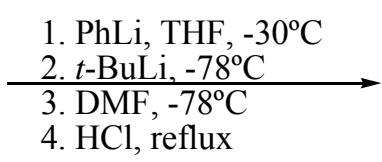

3. $\mathrm{HCl}$, reflux
4.<smiles>CC(C)(C)Cc1c[nH]c2ncccc12</smiles>

$24(40 \%)$

Scheme 6. Organolithium mediated synthesis of 7-azaindole derivative

Another palladium-catalyzed reaction utilized for the synthesis of azaindoles is the Sonogashira coupling. This type of coupling between terminal alkynes and $o-$ aminohalopyridines gave fairly high yields. An alternate route is the cyclization using internal alkynes. Generally, the efficiency of these reactions greatly depends on the nitrogen protecting group in the azaindoles precursors. In addition, the presence of $\mathrm{LiCl}$ is essential to obtain good yields, as noted by Yum et al (Scheme 7). ${ }^{4,5}$ 
<smiles>CC(C)(C)Nc1ccncc1I</smiles>

25

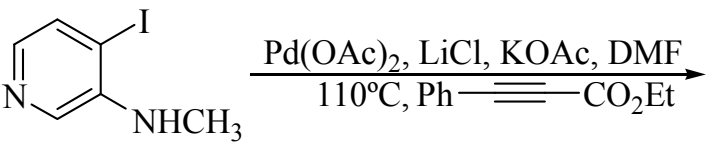

28

$$
\stackrel{\mathrm{PdCl}_{2}\left(\mathrm{PPh}_{3}\right)_{2}, \mathrm{CuI}}{\mathrm{Et}_{3} \mathrm{~N}, \mathrm{rt}, \mathrm{Ph} \stackrel{=}{=}}
$$

$$
\underset{\mathrm{Pd}(\mathrm{OAc})_{2}, \mathrm{LiCl}, \mathrm{KOAc}, \mathrm{DMF}}{110^{\circ} \mathrm{C}, \mathrm{Ph} \stackrel{\overline{=}}{\overline{\mathrm{CO}}} \mathrm{CO}_{2} \mathrm{Et}}
$$$$
26(95 \%)
$$<smiles></smiles>

$27(67 \%)$<smiles>CCOC(=O)c1c(-c2ccccc2)[nH]c2cnccc12</smiles>

29
$(53 \%, 1: 1)$<smiles>CCOC(=O)c1c(-c2ccccc2)c2ccncc2n1C</smiles>

30

Scheme 7. Internal and terminal alkynes in the preparation of azaindoles

Based on observations made by McLaughlin and co-workers, they were able to develop an innovative procedure for Sonogashira couplings, as shown in Scheme $8 .^{17}$ Reductive amination of the inexpensive 3-amino-2-chloropyridine (31) with a ketone or aldehyde, followed by Sonogashira coupling and cyclization, afforded the desired N-protected azaindole derivative 33 .<smiles>Nc1cccnc1Cl</smiles>

31

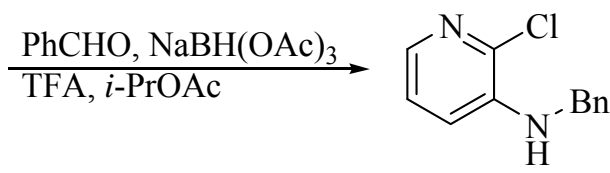

$32(94 \%)$

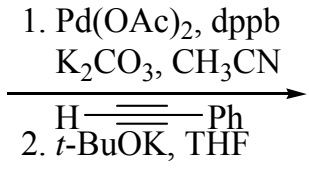

$\underset{\text { 2. } t-\mathrm{Bu} \overline{\overline{\mathrm{OK}}}, \mathrm{THF}}{\stackrel{\mathrm{Ph}}{\mathrm{K}_{2} \mathrm{CO}_{3}, \mathrm{CH}_{3} \mathrm{CN}}}$<smiles></smiles>

$33(87 \%)$

Scheme 8. Synthesis of 4-azaindole derivative 33

Kumar et al $^{18}$ carried out a Suzuki reaction between iodide $\mathbf{3 4}$ and vinyl borate 35 followed by acidic hydrolysis to give azaindole $\mathbf{3 6}$ (Scheme 9). 


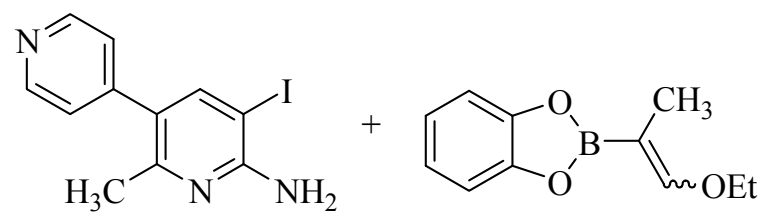

34

35

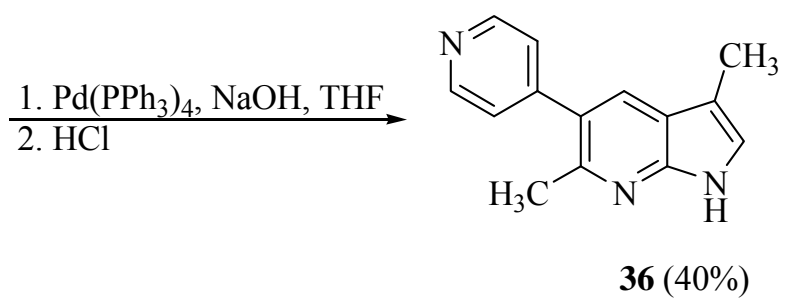

Scheme 9. Suzuki coupling for the synthesis of 7 -azaindole derivative 36

Yamanaka et $a l^{19}$ reported the Stille couplings of halonitro- and nitrotriflyloxypyridines with (Z)-1-ethoxy-2-tributylstannylethene using 0.03 equivalents of $\mathrm{PdCl}_{2}\left(\mathrm{PPh}_{3}\right)_{2}, 1.0$ equivalent of $\mathrm{Et}_{4} \mathrm{NCl}$ in acetonitrile to construct nitrovinylpyridines (Scheme 10). In some instances both, E and Z, isomers were obtained. Subsequent reduction of the nitro moiety in $\mathbf{3 8}$ provided aminopyridine, which was successfully cyclized under acidic conditions in good yield.

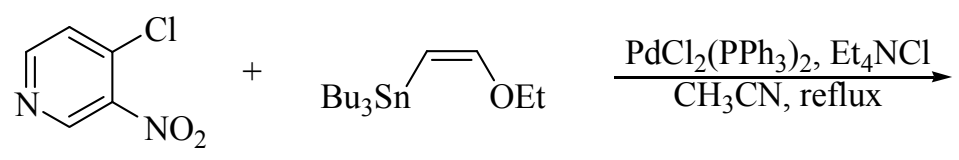

37

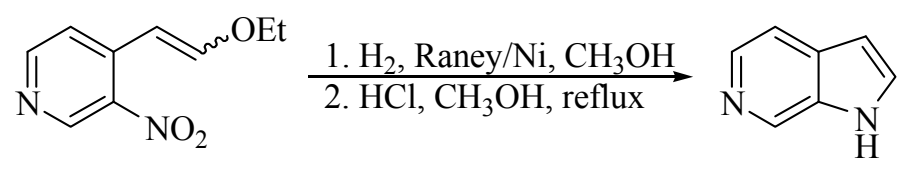

$38(83 \%)$

$3(87 \%)$

Scheme 10. Yamanaka's azaindole synthesis 
A noteworthy reaction path was investigated and drastically improved by BoehringerIngelheim. ${ }^{11}$ Nitrostyrylpyridines were reduced in the presence of stannous chloride, providing a hydroxylamine intermediate, which was oxidized to the corresponding 1hydroxy-2-phenylazaindole (Scheme 11). The N-hydroxyindole could be reduced to afford the azaindole in good to excellent yield.

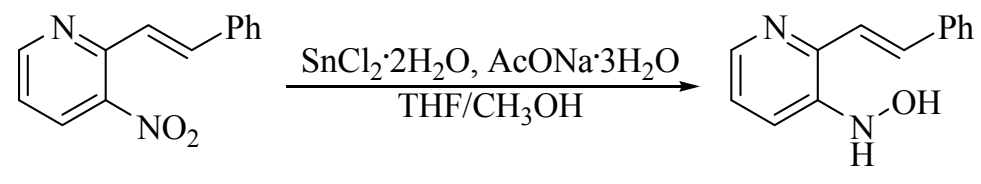

39

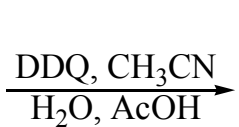

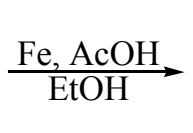

$41(93 \%)$
40 (98\%)<smiles>c1ccc(-c2cc3ncccc3[nH]2)cc1</smiles>

$42(93 \%)$

Scheme 11. Boehringer-Ingelheim azaindole synthesis

\subsection{Pyrrolodiazines}

Pyrrolodiazines, or diazaindoles, are heterocyclic compounds having a pyrrole ring fused to a six-membered aromatic ring containing two nitrogen atoms (Fig 2). In comparison, the pyrrolodiazines have not been studied as extensively as the azaindoles. Most of the methods described in the literature involve a Sonogashira coupling or a condensation reaction with a methyldiazine. 
<smiles>c1cnc2[nH]ccc2n1</smiles>

43: $5 H$-pyrrolo[2,3-b]pyrazine (4,7-diazaindole)<smiles>c1cc2cc[nH]c2nn1</smiles>

46: 7H-pyrrolo[2,3-c]pyridazine (6,7-diazaindole)<smiles>c1ncc2cc[nH]c2n1</smiles>

44: 7H-pyrrolo[2,3-d]pyrimidine (5,7-diazaindole)<smiles>c1cc2cnncc2[nH]1</smiles>

47: $1 H$-pyrrolo[2,3-d]pyridazine (5,6-diazaindole)<smiles>c1ncc2[nH]ccc2n1</smiles>

45: $5 H$-pyrrolo[3,2-d]pyrimidine (4,6-diazaindole)<smiles>c1cc2[nH]ccc2nn1</smiles>

48: $5 H$-pyrrolo[3,2-c]pyridazine (4,5-diazaindole)

Figure 2. Diazaindoles 43-48

It is evident that the interest for pyrrolodiazines is increasing, but synthetic routes are scarce. Efforts towards the synthesis of pyrrolopyrazines have been centered on the lithiation of a 2-alkyl substituted pyrazine followed by reaction with arylnitrile (Scheme 12). ${ }^{20}$ Disadvantages of this method are the limited amount of commercially available 2alkyl substituted pyrazines and the low reaction yields, which varies depending on the substituent in the arylnitrile partner. ${ }^{21}$

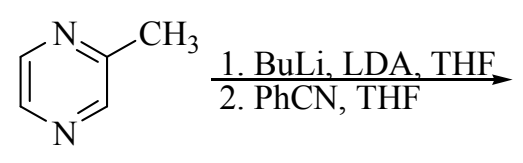

49<smiles>c1ccc(-c2cc3nccnc3[nH]2)cc1</smiles>

$50(37 \%)$

Scheme 12. Synthesis of 4,7-diazaindole derivative 50

Hopkins et $\mathrm{al}^{22}$ reported the Sonogashira coupling of readily available 2-amino-3chloropyrazine (51) with phenylacetylene followed by base-induced cyclization (Scheme 
13), as well as the one-pot heteroannulation with 2-chloro-3-( $\mathrm{N}$-methanesulfonamide)pyrazine (53) (Scheme 14).<smiles>Nc1nccnc1Cl</smiles>

51
$\frac{\mathrm{PdCl}_{2}\left(\mathrm{PPh}_{3}\right)_{2}, \mathrm{CuI}, \mathrm{Et}_{3} \mathrm{~N}}{\mathrm{NMP}, \mathrm{Ph} \stackrel{\bar{\equiv}}{\longrightarrow} \mathrm{H}}$<smiles>NS(=O)(=O)Nc1nccnc1Cl</smiles>

53<smiles>Nc1nccnc1C#Cc1ccccc1</smiles>

$52(73 \%)$

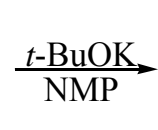<smiles>c1ccc(-c2cc3nccnc3[nH]2)cc1</smiles>

$50(60 \%)$

Scheme 13. Synthesis of 50 via Sonogashira coupling
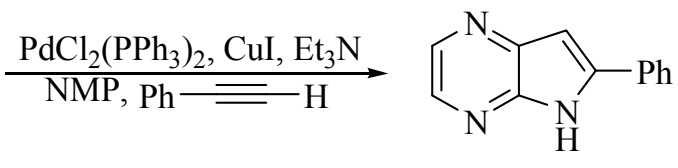

$50(67 \%)$

Scheme 14. One-pot synthesis of 50

A different methodology was reported by Meltzer and co-workers. ${ }^{23}$ Their reaction involved the treatment of 2-amino-3-methylpyrazine (54) with the Vilsmeier reagent, followed by hydrolysis of the immonium salt $\mathbf{5 5}$ to afford the desired product $\mathbf{5 6}$ (Scheme 15). All the couplings reported in the literature involve an aminopyrazine. To our knowledge, there is no published report for a nitropyrazine coupling.

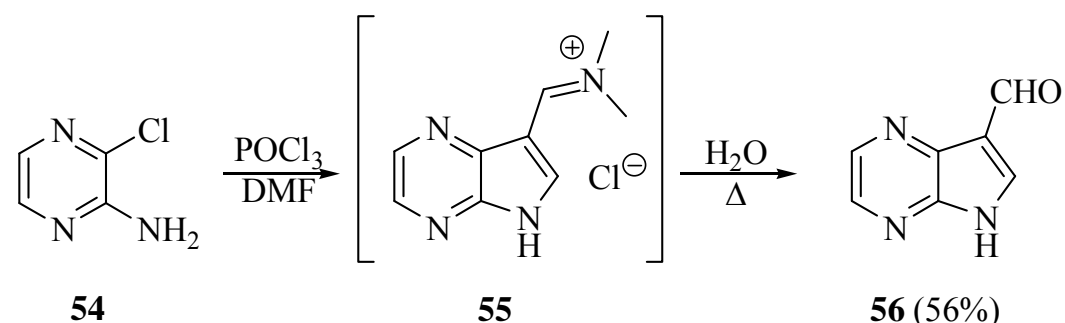

Scheme 15. Synthesis of 4,7-diazaindole derivative 56 
Annulation of a pyrrole ring onto a pyrimidine, construction of a pyrimidine ring onto an aminopyrrole or the transformation of a bicyclic heterocycle are the most commonly used methods for the synthesis of pyrrolopyrimidines. ${ }^{6}$ According to Tumkevicius et al, ${ }^{24}$ only a few reports exist in the literature regarding the synthesis of 4,5-diazaindole (45) from 5nitro-pyrimidines. Tumkevicius and co-workers developed two-step (Scheme 16) and one-pot (Scheme 17) routes using a Sonogashira coupling for the synthesis of $\mathbf{5 9 .}$ Comparing both ways, even though there is no intermediate purification, a lower yield was the main disadvantage of the one-pot synthesis.

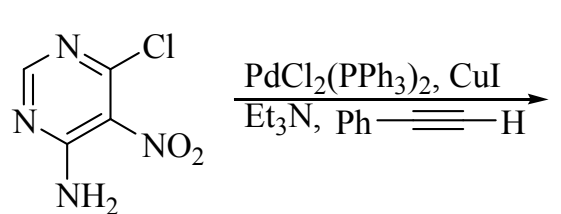

57<smiles>Nc1ncnc(C#Cc2ccccc2)c1[N+](=O)[O-]</smiles>

$58(75 \%)$

$59(95 \%)$

Scheme 16. Two-step reaction synthesis of 59<smiles>Nc1ncnc(Cl)c1[N+](=O)[O-]</smiles>

1. $\mathrm{PdCl}_{2}\left(\mathrm{PPh}_{3}\right)_{2}, \mathrm{CuI}$ $\underset{\mathrm{Et}_{3} \mathrm{~N}, \mathrm{Ph} \stackrel{\overline{=}}{\text { 2. Pyridine, } \Delta} \mathrm{H}}{\longrightarrow}$

57<smiles>Nc1ncnc2c1N([O-])C(c1ccccc1)C2=O</smiles>

$59(49 \%)$

Scheme 17. One-pot synthesis of 59

The method reported by Townsend et al ${ }^{6}$ started with bromination of 2,4-dimethoxy-6methyl-5-nitropyrimidine (60) (Scheme 18). Bromide displacement was carried out by reaction of sodium cyanide in cold aqueous methanol, followed by cyclization to give the 
desired product 63. In an alternate route (Scheme 19), 60 was treated with tertbutoxybis(dimethylamino)-methane (BBDM) to obtain the cyclization precursor 64 . This was catalytically hydrogenated with Raney nickel to get diazaindoles 63 . Low cyclization yield is the major drawbacks for both pathways.

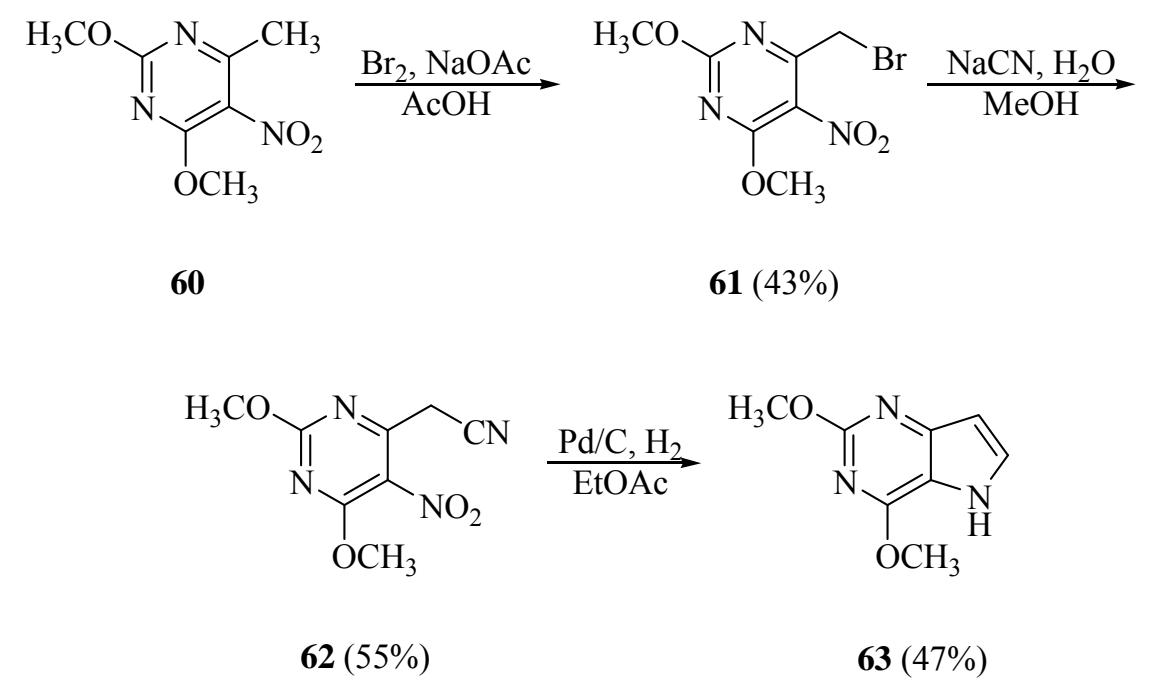

Scheme 18. Synthesis of 4,6-diazaindole derivative 63

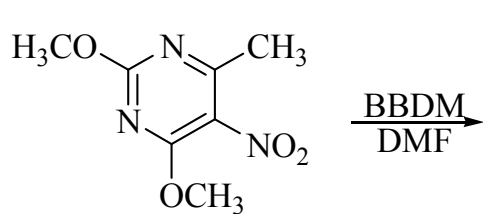

60

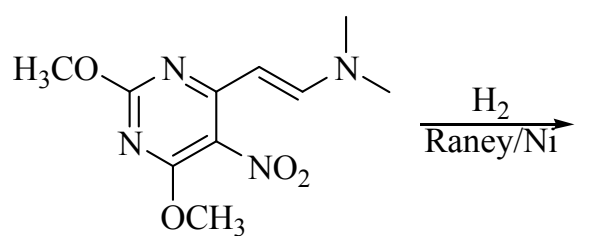

$64(77 \%)$<smiles>COc1nc(OC)c2[nH]ccc2n1</smiles>

$63(27 \%)$

Scheme 19. Synthesis of pyrrolo[3,2-d]pyrimidine derivative 63

Similar reports were described by Tkachenko et $a l^{25}$ and Müller et $a l,{ }^{26}$ in which various 5-nitro-6-styryluracil derivatives were submitted to reductive cyclization in the presence of zinc (Scheme 20) and triethyl phosphite (Scheme 21), respectively. 
<smiles>Cc1c([N+](=O)[O-])c(=O)n(C)c(=O)n1C</smiles>

65

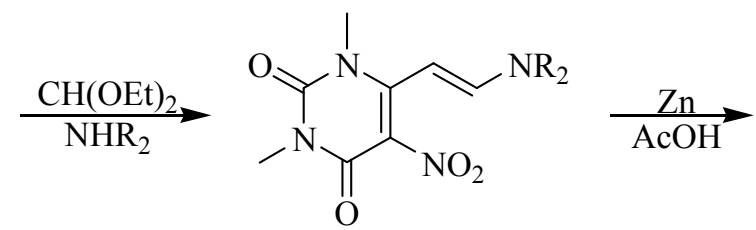

$66(37-81 \%)$<smiles>Cn1c(=O)c2[nH]ccc2n(C)c1=O</smiles>

$67(71 \%)$

Scheme 20. Tkachenko's synthesis of $\mathbf{6 7}$

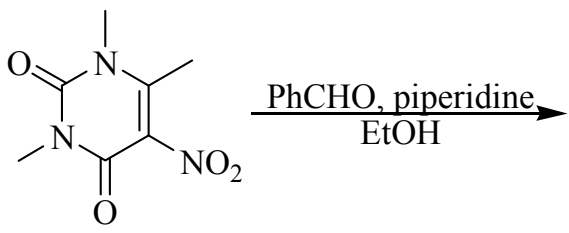

65<smiles>CCO[PH2](=O)c1ccccc1/C=C/c1c([N+](=O)[O-])c(=O)n(C)c(=O)n1C</smiles>

$68(66 \%)$<smiles>Cn1c(=O)c2[nH]c(-c3ccccc3)cc2n(C)c1=O</smiles>

$69(11 \%)$

Scheme 21. Müller's preparation of 4,6-diazaindole derivative 69

It is worth mentioning the 1,3-dipolar cycloaddition reaction of fervenulin 4-oxide (70) with dimethyl acetylenedicarboxylate (DMAD) described by Senga and co-workers (Scheme 22), ${ }^{27}$ in which they obtained 71 in good yields.<smiles></smiles>

70<smiles>CC(=O)c1c[nH]c2c(=O)n(C)c(=O)n(C)c12</smiles>

$71(62 \%)$

Scheme 22. Senga's synthesis of derivative 71

A number of pyrrolopyridazines have been prepared. Castle et $a l^{28}$ described the synthesis of pyrrolo[3,2-c]pyridazine derivative 74. As shown in Scheme 23, 4-amino-3methylpyridazine (72) was treated with triethyl orthoformate and anhydrous $\mathrm{HCl}$ to 
obtain 73. This was treated with diethyl oxalate and potassium ethoxide to obtain the enolate that readily cyclized to $\mathbf{7 4}$, which was obtained in good yield.

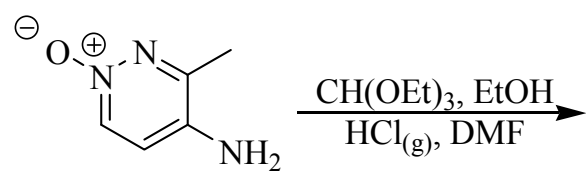

72

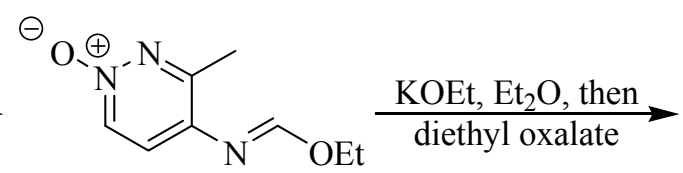

$73(80 \%)$

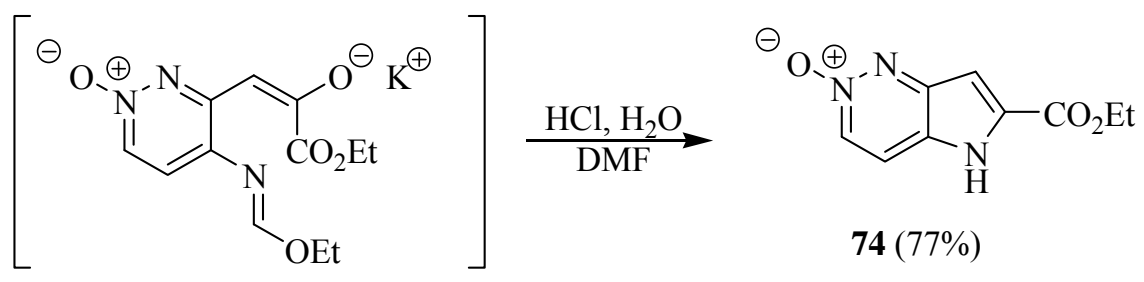

Scheme 23. Synthesis of ethyl pyrrolo[3,2-c]pyridazine-6-carboxylate 2-oxide 74

Another method employed is the cyclization of ortho-(Boc-amino)alkynylpyridazines.

Described by Riether et al, ${ }^{29}$ this methodology (Scheme 24) utilizes a Sonogashira coupling reaction to obtain the cyclization precursor (76). This precursor is submitted to a DBU-mediated cyclization to obtain the desired pyrrolopyridazines in excellent yields.

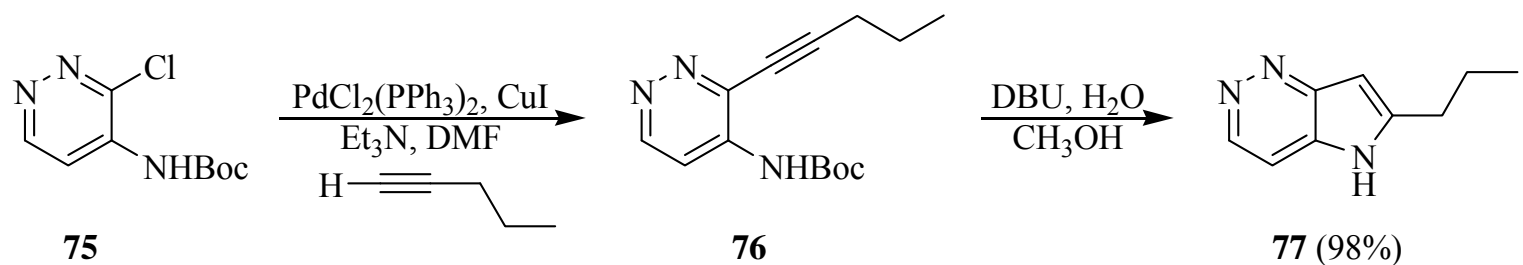

Scheme 24. Synthesis of 4,5-diazaindole derivative 77 


\subsection{Reductive $N$-Heteroannulation Reactions}

A new methodology for the synthesis of indoles was developed in our group. ${ }^{30}$ This procedure involves the palladium-catalyzed reductive $N$-heteroannulation of 2nitrostyrenes (Scheme 25). The presence of three reagents was found to be critical in this reaction: a palladium catalyst, a ligand (usually a phosphine), and carbon monoxide. This reaction has been successful in the synthesis of a variety of functionalized indoles, carbazoles, and benzimidazoles, among others.

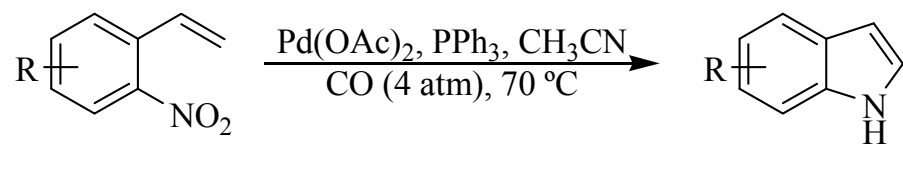

78

79

Scheme 25. Palladium-catalyzed $N$-heteroannulation

Similar procedures have been reported in the literature. Watanabe et al ${ }^{31}$ published a related procedure in which annulations of nitroarenes with unsaturated groups in the ortho position lead to indole formation in the presence of catalytic amount of $\mathrm{PdCl}_{2}\left(\mathrm{MeCN}_{2}\right.$, triphenylphosphine, excess tin dichloride, and $20 \mathrm{~atm}$ of carbon

monoxide (Scheme 26). Another similar example was reported by Cenini et al ${ }^{32}$ using $\operatorname{Pd}(\mathrm{TMB})_{2} / \mathrm{TMPhen}(\mathrm{TMBH}=2,4,6$-trimethylbenzoic acid; $\mathrm{TMPhen}=3,4,7,8$ tetramethyl-1,10-phenanthroline) as the catalyst (Scheme 27). 


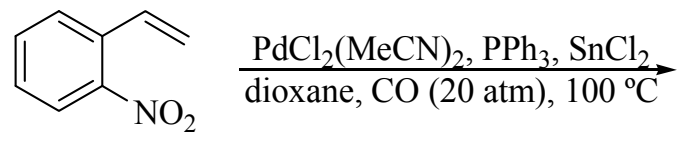

80

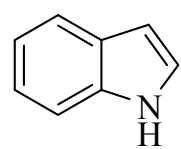

81

Scheme 26. Watanabe's indole synthesis<smiles>[R]C=Cc1ccccc1[N+](=O)[O-]</smiles>

82

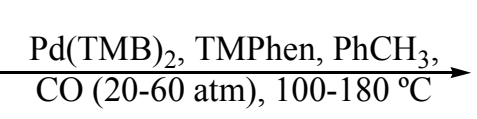
$\mathrm{CO}(20-60 \mathrm{~atm}), 100-180^{\circ} \mathrm{C}$<smiles>[R]c1cc2ccccc2[nH]1</smiles>

83

Scheme 27. Cenini's indole synthesis

All previously described methods generally produce good yields of indoles.

Nevertheless, compared to the procedure developed in Söderberg's group, most of these methods employ very harsh reaction conditions. The conditions developed are much milder, proceed at significantly lower pressure and temperature, and do not require the addition of a Lewis Acid such as tin dichloride. Due to the success obtained in the synthesis of a variety of indole, carbazole, and benzimidazole derivatives, we decided to apply this new method to the synthesis of pyrrolopyridines and different pyrrolodiazines. The synthesis and attempted synthesis of these compounds is presented herein. 


\section{Results and Discussion}

\subsection{Synthesis of Pyrrolopyridines}

It was envisioned that azaindoles could be prepared employing one or two successive palladium-catalyzed reactions. Azaindoles precursors could be prepared by condensation of an $o$-methylnitropyridine and benzaldehyde or utilizing a Stille coupling, similar to the one previously described by Yamanaka, between an $o$-halonitropyridine and vinyltributyl stannane. The precursors could then be submitted to the palladium-catalyzed $N$ heteroannulation, which could provide the corresponding azaindoles, as shown in Scheme 28.

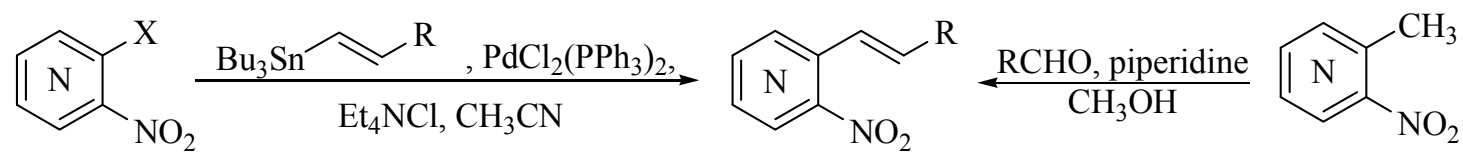
$\mathrm{X}=\mathrm{Cl}, \mathrm{Br}, \mathrm{OTf}$

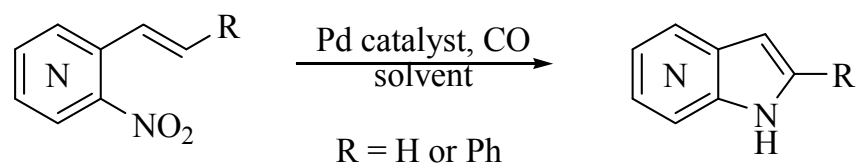

Scheme 28. Strategy for azaindole preparation

Commercially available 2-chloro-3-nitropyridine was subjected to two consecutive palladium-catalyzed reactions. Following the procedure reported by Li et al, ${ }^{33} 2$-vinyl-3nitropyridine (84) was obtained and subsequent cyclization in the presence of $\operatorname{Pd}(\mathrm{dba})_{2}$, 1,10-phenanthroline and 6 atm of carbon monoxide, afforded the desired 4-azaindole (1) (Scheme 29). As shown in Scheme 30, 2-nitro-3-trifluoromethane-sulfonyloxypyridine 
(85) was formed by reaction of commercially available 3-hydroxy-2-nitropyridine with trifluoromethanesulfonic anhydride in pyridine. A similar protocol to that described for 1, a Stille coupling followed by cyclization, was used on 85 to obtain 7-azaindole (4) in moderate yield.

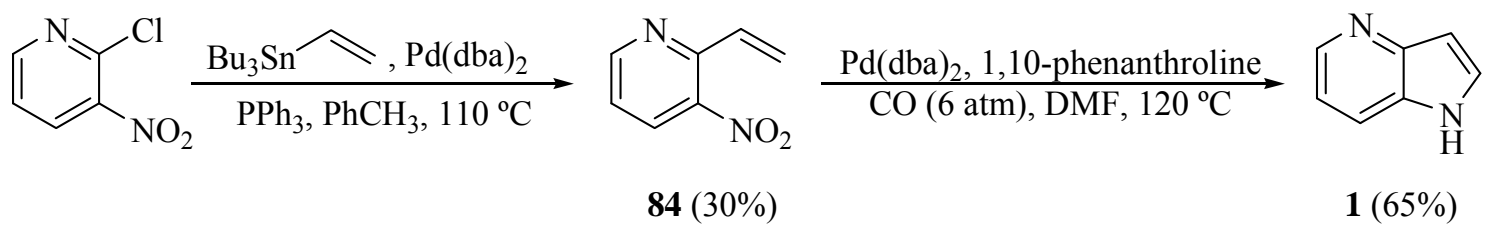

Scheme 29. Synthesis of 4-azaindole 1

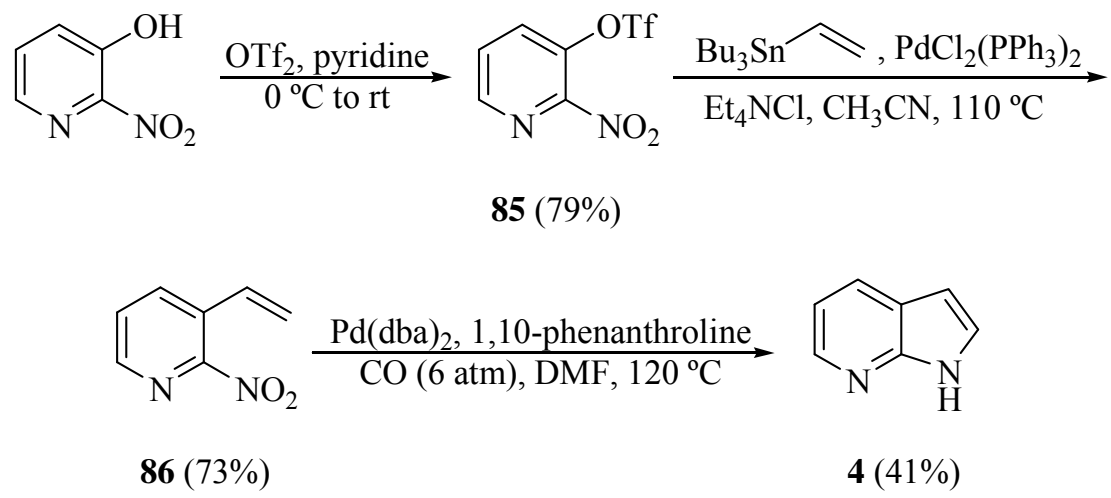

Scheme 30. Synthesis of 7-azaindole 4

The synthesis of 2-phenyl-5-azaindole (89) started with nitration of the commercially available 3-picoline N-oxide (Scheme 31). Condensation of the nitrated product 87 with benzaldehyde followed by palladium-catalyzed $N$-heteroannulation afforded the desired deoxygenated azaindole, as confirmed by X-ray crystallography, in excellent yield. In the same manner, condensation of 3-nitro-4-picoline with benzaldehyde gave 90, which was cyclized to 2-phenyl-6-azaindole (91) in excellent yield (Scheme 32). 


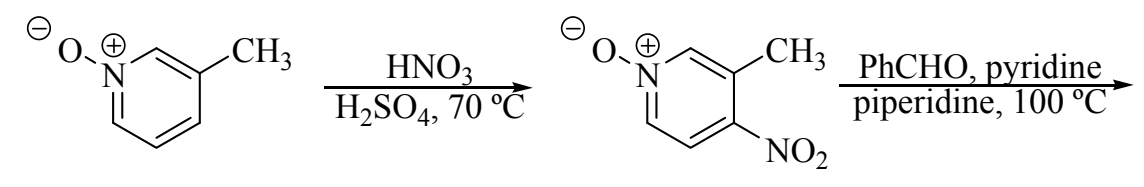

$87(66 \%)$

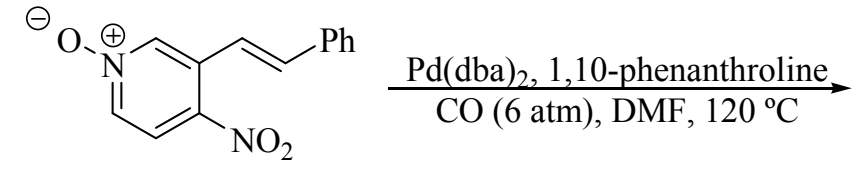

$88(27 \%)$

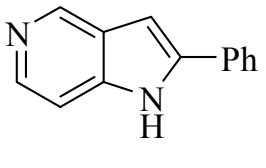

$89(91 \%)$

Scheme 31. Synthesis of 2-phenyl-5-azaindole 89
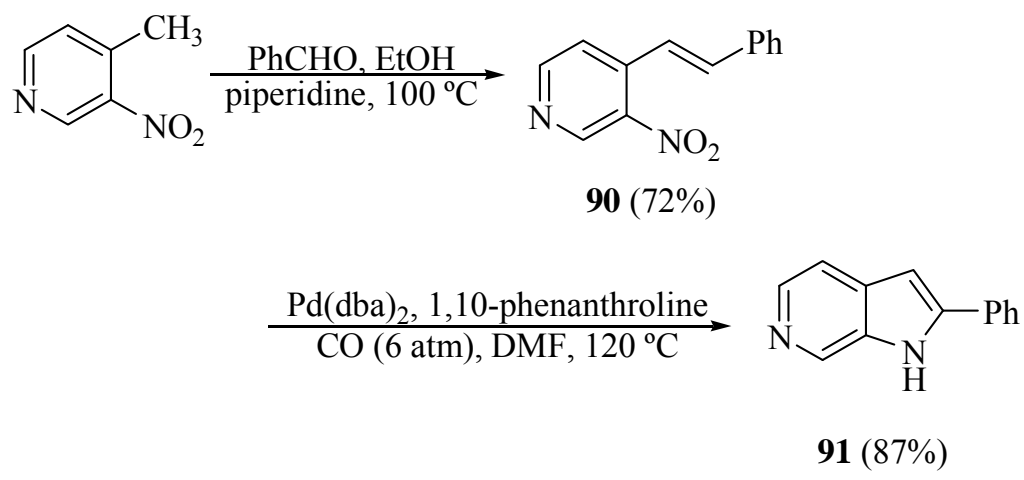

Scheme 32. Synthesis of 2-phenyl-6-azaindole 91

\subsection{Synthesis of Pyrrolopyrimidines}

The synthesis to a pyrrolo[3,2-d]pyrimidine derivative commenced with the treatment of commercially available 4,6-dihydroxy-5-nitropyrimidine with phosphorus oxychloride and N,N-diethylaniline to obtain 4,6-dichloro-5-nitropyrimidine (92) in good yield (Scheme 33). 


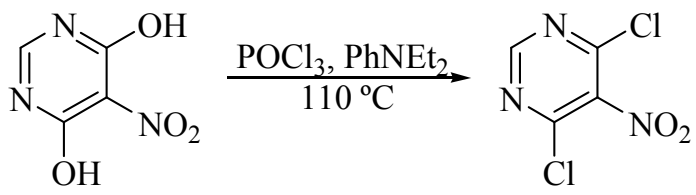

$92(78 \%)$

Scheme 33. Synthesis of 4,6-dichloro-5-nitropyrimidine 92

The next step was a coupling reaction to obtain a vinyl group ortho to the nitro moiety. As shown in Table 1, all the coupling attempts to obtain the desired product were ineffective. Variations of the Stille and Suzuki couplings were attempted with 92 but all failed. In an effort to obtain a more reactive substituent, it was also attempted to get halogens and triflates but these endeavors were futile. 


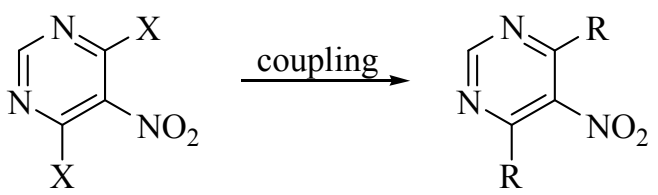

\begin{tabular}{|c|c|c|c|c|c|}
\hline Entry & $\mathbf{X}$ & $\mathbf{R}$ & Conditions (\% Yield) & $\begin{array}{c}\text { Temp } \\
\left({ }^{\circ} \mathrm{C}\right)\end{array}$ & $\begin{array}{c}\text { Time } \\
\text { (h) }\end{array}$ \\
\hline 1 & $\mathrm{Cl}$ & vinyl & $\mathrm{CH}_{2} \mathrm{CHSnBu}_{3}, \mathrm{PdCl}_{2}\left(\mathrm{PPh}_{3}\right)_{2}, \mathrm{Et}_{4} \mathrm{NCl}, \mathrm{CH}_{3} \mathrm{CN}$ & 110 & 73 \\
\hline $2^{34}$ & $\mathrm{Cl}$ & vinyl & $\mathrm{CH}_{2} \mathrm{CHSnBu}_{3}, \mathrm{PdCl}_{2}\left(\mathrm{PPh}_{3}\right)_{2}, \mathrm{PPh}_{3}, \mathrm{PhCH}_{3}, \mathrm{~N}_{2}$ & 110 & 96 \\
\hline 3 & $\mathrm{Cl}$ & vinyl & $\mathrm{CH}_{2} \mathrm{CHSnBu}_{3}, \mathrm{Pd}(\mathrm{dba})_{2}, \mathrm{PPh}_{3}, \mathrm{CuI}, \mathrm{DMF}$ & $\mathrm{rt}$ & 43 \\
\hline 4 & $\mathrm{Cl}$ & vinyl & $\mathrm{CH}_{2} \mathrm{CHSnBu}_{3}, \mathrm{Pd}(\mathrm{dba})_{2}, \mathrm{PPh}_{3}, \mathrm{CuI}, \mathrm{DMF}$ & 80 & 48 \\
\hline $5^{35}$ & $\mathrm{Cl}$ & vinyl & 22, $\mathrm{Pd}(\mathrm{OAc})_{2}, \mathrm{PPh}_{3}, \mathrm{Na}_{2} \mathrm{CO}_{3}, \mathrm{DME}$ & 85 & 18 \\
\hline $6^{36}$ & $\mathrm{Cl}$ & vinyl & 22, $\mathrm{PdCl}_{2}\left(\mathrm{PPh}_{3}\right)_{2}, \mathrm{~K}_{3} \mathrm{PO}_{4} \cdot 7 \mathrm{H}_{2} \mathrm{O}, \mathrm{THF}$ & 70 & 20.5 \\
\hline $7^{37}$ & $\mathrm{Cl}$ & vinyl & 22, $\mathrm{Pd}(\mathrm{dba})_{2}, \mathrm{PPh}_{3}, \mathrm{~K}_{2} \mathrm{CO}_{3}, \mathrm{H}_{2} \mathrm{O} / \mathrm{DME}$ & 90 & 23 \\
\hline $8^{38}$ & $\mathrm{Cl}$ & I & $\mathrm{HI}$ & $\mathrm{rt}$ & 24 \\
\hline 9 & $\mathrm{OH}$ & OTf & $\mathrm{OTf}_{2}, \mathrm{Et}_{3} \mathrm{~N}, \mathrm{~N}_{2}$ & $\mathrm{rt}$ & 21 \\
\hline 10 & $\mathrm{OH}$ & OTf & $\mathrm{OTf}_{2}, i \mathrm{Pr}_{2} \mathrm{Net}, \mathrm{CH}_{2} \mathrm{Cl}_{2}, \mathrm{~N}_{2}$ & 0 & 3 \\
\hline $11^{39}$ & $\mathrm{OH}$ & $\mathrm{Br}$ & $\mathrm{P}_{2} \mathrm{O}_{5}, \mathrm{TBAB}, \mathrm{PhCH}_{3}$ & 100 & 3 \\
\hline
\end{tabular}

Table 1. Coupling conditions evaluated

The difficulty of the couplings led us to examine the condensation reaction previously used with the pyridines. Remennikov et $a l^{40}$ reported the conversion of 92 to 4-methoxy6-methyl-5-nitropyrimidine (94), which would allow the condensation reaction to occur. Decarboxylation of $\mathbf{9 3}$ and subsequent condensation of the resulting compound $\mathbf{9 4}$ with benzaldehyde afforded the desired 4-methoxy-5-nitro-6-styrylpyrimidine (95). Treatment of this compound with $\operatorname{Pd}(\mathrm{dba})_{2}$ in the presence of 1,10-phenanthroline and DMF gave the corresponding 4-methoxy-6-phenyl-5H-pyrrolo[3,2-d]pyrimidine (96) in high yield. 
$\underset{\mathrm{Cl}}{\stackrel{\text { 2,4-pentanedione }}{\mathrm{NaH}, \mathrm{THF}, \mathrm{rt}, \mathrm{N}_{2}}}$

92<smiles>CC(=O)C(C(C)=O)c1ncnc(Cl)c1[N+](=O)[O-]</smiles>

$93(64 \%)$<smiles>COc1ncnc(C)c1[N+](=O)[O-]</smiles>

$94(69 \%)$
PhCHO, pyridine piperidine, $100{ }^{\circ} \mathrm{C}$<smiles>COc1ncnc(/C=C/c2ccccc2)c1[N+](=O)[O-]</smiles>

$95(41 \%)$
$\underset{\mathrm{Pd}(\mathrm{dba})_{2}, 1,10 \text {-phenanthroline }}{\longrightarrow}$ $\mathrm{CO}$ (6 atm), DMF, $120^{\circ} \mathrm{C}$<smiles>COc1ncnc2cc(-c3ccccc3)[nH]c12</smiles>

$96(82 \%)$

Scheme 34. Synthesis of 5H-pyrrolo[3,2-d]pyrimidine derivative 96

For the synthesis of the $7 \mathrm{H}$-pyrrolo[2,3-d]pyrimidine derivative, due to the very limited starting material availability, the only plausible route was condensation of 2,4-dihydroxyor 2,4-dichloro-5-methyl-6-nitropyrimidine, followed by standard cyclization conditions. As shown in Scheme 35, various attempts were made, but no nitration of either thymine or 2,4-dichloro-5-methylpyrimidine (97) occurred.<smiles>Cc1cnc(O)nc1O[Na]</smiles>

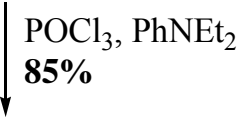<smiles>Cc1cnc(Cl)nc1Cl</smiles>

97<smiles>Cc1c(O)nc(O)nc1[N+](=O)[O-]</smiles><smiles>Cc1cnc(O)nc1O</smiles>
not observed<smiles>Cc1c(Cl)nc(Cl)nc1[N+](=O)[O-]</smiles>
not observed<smiles>Cc1cnc(Cl)nc1Cl</smiles>

97

Scheme 35. Attempted synthesis of 6-nitro-substituted pyrimidine 
Taking into consideration other work with diazines, it was believed that the nitration could proceed with little or no problem with thymine N-oxide or 2,4-dichloro-5methylpyrimidine N-oxide. Two reaction conditions were tried, but failed to give any Noxide (Scheme 36).<smiles>Cc1cnc(O)nc1O</smiles><smiles></smiles><smiles>Cc1cnc(O)nc1O</smiles><smiles>Cc1cnc(Cl)nc1Cl</smiles><smiles></smiles><smiles>Cc1cnc(Cl)nc1Cl</smiles>
97 not observed 97

Scheme 36. Attempted preparation of pyrimidine N-oxides

Due to the lack commercial availability and difficulty in preparation of a suitable pyrimidine, it was not feasible to design a reaction route for the synthesis of $7 \mathrm{H}$ pyrrolo[2,3-d]pyrimidine or a derivative.

\subsection{Synthesis of Pyrrolopyridazines}

The efforts started with 3-chloro-6-methylpyridazine, due to the limited commercially available starting materials. To obtain the cyclization precursors, it was envisioned that it was possible to perform either one of the procedures previously described with a nitro-3chloro-6-methylpyridazine. After the initial nitration attempt (Scheme 37$)^{35}$ failed and reviewing the literature, it was concluded that it was necessary to oxidize a nitrogen for 
the nitration reaction to proceed. It is important to note that nitration occurs para to the N-oxide. At this early stage in the synthesis, it was not relevant which nitrogen was oxidized, considering that nitration at either carbon would allow us to carry on with the synthesis.
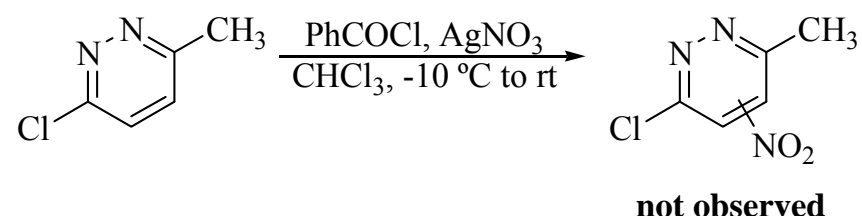

Scheme 37. Failed nitration of 3-chloro-6-methylpyridazine

Abiding by the procedure described by Hideo and co-workers, ${ }^{41}$ a separable mixture of three products was obtained, all in very low yields. After several trials to increase the yields or to get one predominant product and after extensive NMR studies, it was concluded that the mixture consisted of 98, 99, and $\mathbf{1 0 0}$ (Scheme 38). In addition, when submitting 98 to the conditions shown in Scheme 37, no nitrated product was obtained.<smiles>Cc1ccc(Cl)nn1</smiles>

\section{Scheme 38. Pyridazine N-oxides 98-100}

Re-evaluation of the data acquired and the literature, led to the synthesis of the symmetrical 3,6-dimethylpyridazine (101), which would give only one N-oxide.

Following the publications of Foote et $a l^{42}$ and Fariña et $a l^{43}$ the desired pyridazine was obtained (Scheme 39), which gave excellent results for the oxidation. Nitration of the 
resulting N-oxide 102 gave good yield and was treated with benzaldehyde to afford the desired 6-methyl-4-nitro-3-styrylpyridazine 1-oxide (104). Palladium-catalyzed reductive $N$-heteroannulation of $\mathbf{1 0 4}$ gave 3-methyl-6-phenyl-5H-pyrrolo[3,2c]pyridazine (105) in good yield.
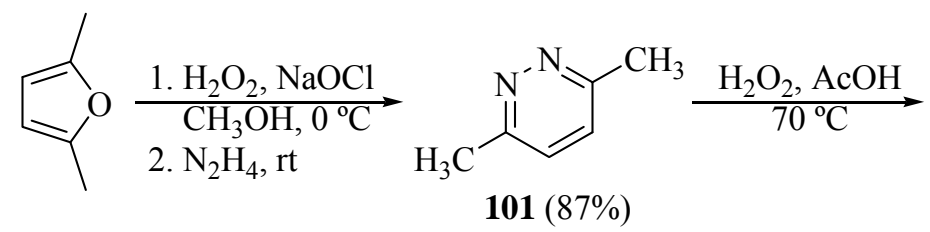<smiles></smiles>

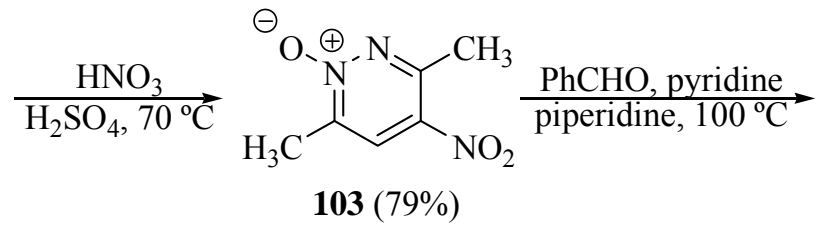<smiles></smiles>
$\underset{\mathrm{Pd}(\mathrm{dba})_{2}, 1,10 \text {-phenanthroline }}{\mathrm{CO}(6 \mathrm{~atm}), \mathrm{DMF}, 120^{\circ} \mathrm{C}}$<smiles>Cc1cc2[nH]c(-c3ccccc3)cc2nn1</smiles>

Scheme 39. Synthesis of 4,5-diazaindole derivative 105

\subsection{Attempted Synthesis of Pyrrolopyrazine}

It was envisioned that the synthesis towards $5 H$-pyrrolo[2,3-b]pyrazine or a derivative could begin using the procedure reported by Kaupp et $a l^{44}$ to obtain $1,4-$ dihydroquinoxaline-2,3-dione (106). As shown in Scheme 40, o-phenylenediamine was reacted with benzil to make the desired product 106. This was treated with phosphorus oxychloride and phosphorus pentachloride to form 2,3-dichloroquinoxaline (107) in good yield. Dry ammonia was bubbled through to get 108. According to Kaupp, they 
followed Hartman and Schwering ${ }^{45}$ methodology to obtain 2-chloro-3-nitroquinoxaline. This was done by reacting 2-amino-3-chloroquinoxaline with trifluoromethanesulfonic anhydride and dimethylsulfoxide, followed by oxidation with m-CPBA and then ozone. It was decided not to follow this procedure on account of the reaction conditions and also because Kaupp and co-workers reported a low yield. In an effort to find an alternate oxidation route, two ways were evaluated, one utilizing peroxyacetic acid in $\mathrm{CHCl}_{3}$ and the other using hydrogen peroxide, and titanium superoxide $(\mathbf{1 0 9})^{46}$ in methanol but these efforts were unsuccessful.
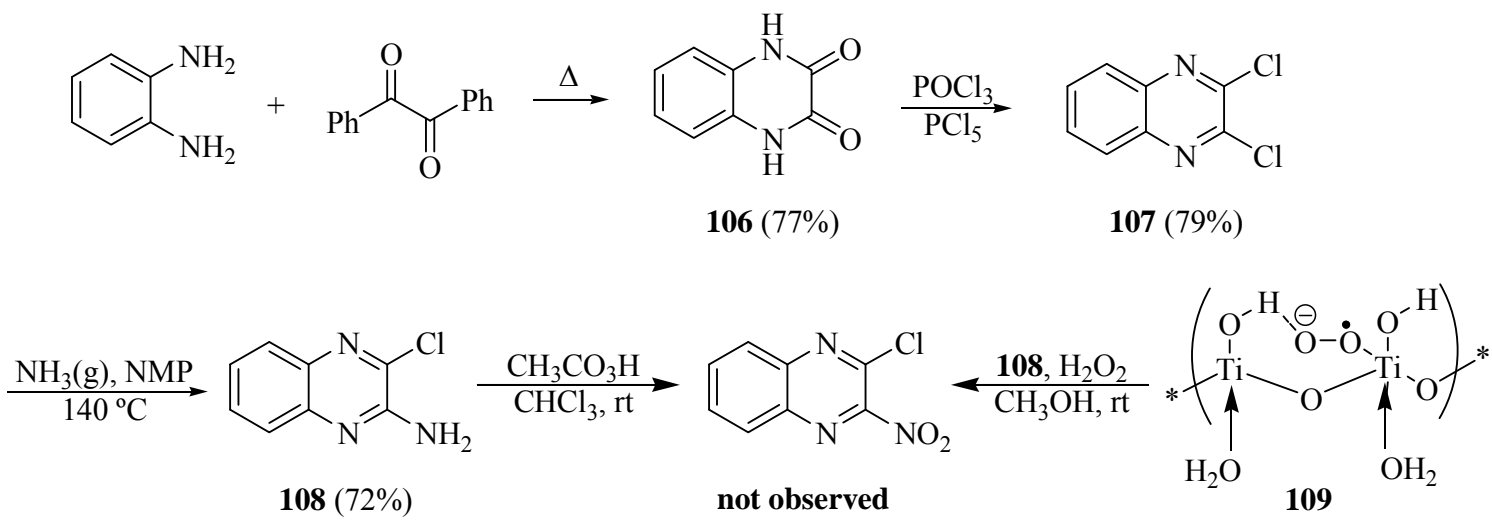

Scheme 40. Initial attempt towards $1 H$-pyrrolo[2,3-b]quinoxaline

The next trial involved the synthesis of 2-hydroxy-3-nitro-5,6-diphenylpyrazine (111). Following the procedure reported by Kaftory and co-workers, ${ }^{47}$ glycinamide hydrochloride was reacted with benzil under basic conditions to obtain 3-hydroxy-5,6diphenylpyrazine (110), which was nitrated to obtain $\mathbf{1 1 1}^{48}$ in good yield (Scheme 41). Formation of the coupling precursors $\mathbf{1 1 2}$ and $\mathbf{1 1 3}$ were accomplished in good and quantitative yields, respectively. 


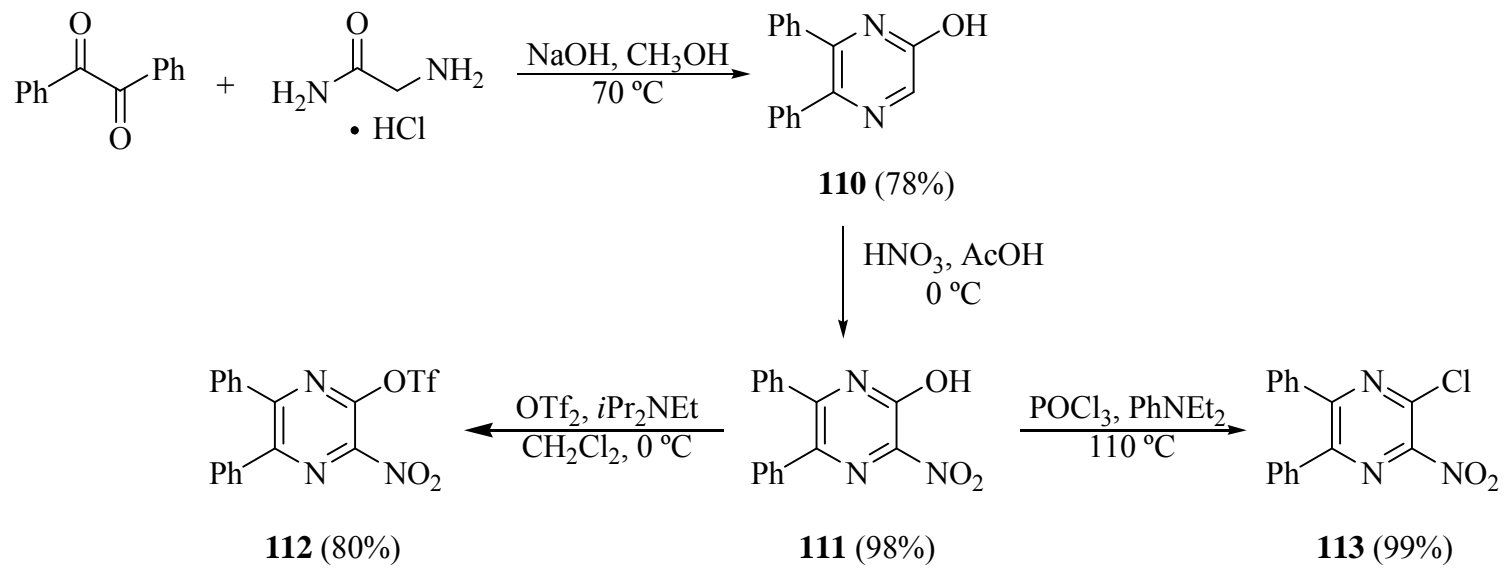

Scheme 41. Synthesis of coupling precursors 112 and 113

As shown in Table 2, several Stille and Suzuki couplings were attempted. Reaction of 112 with vinyltributyl stannane (Entry 1) gave the desired product, but it was not possible to obtain a pure sample. In an effort to circumvent this problem, a $N$-heteroannulation of the crude sample of the Stille coupling was attempted, but no cyclization product was observed. 


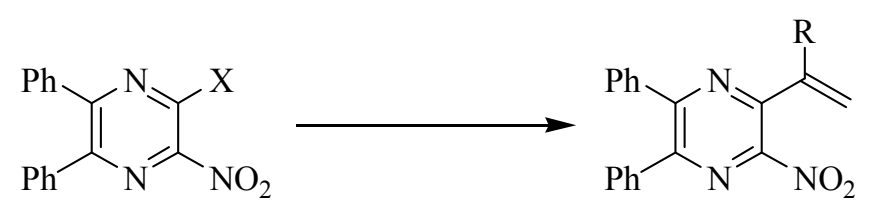

\begin{tabular}{|c|c|c|c|c|c|}
\hline Entry & $\mathbf{X}$ & $\mathbf{R}$ & Conditions (\% Yield) & $\begin{array}{c}\text { Temp } \\
\left({ }^{\circ} \mathrm{C}\right)\end{array}$ & $\begin{array}{c}\text { Time } \\
\text { (h) }\end{array}$ \\
\hline 1 & OTf & $\mathrm{H}$ & $\begin{array}{l}\mathrm{CH}_{2} \mathrm{CHSnBu}_{3}, \mathrm{PdCl}_{2}\left(\mathrm{PPh}_{3}\right)_{2}, \mathrm{Et}_{4} \mathrm{NCl}, \\
\mathrm{CH}_{3} \mathrm{CN} \text { (54) }\end{array}$ & 100 & 92 \\
\hline 2 & OTf & $\mathrm{H}$ & $\begin{array}{l}\mathrm{CH}_{2} \mathrm{CHSnBu}_{3}, \mathrm{PdCl}_{2}(\mathrm{PhCN})_{2}, \mathrm{Ph}_{3} \mathrm{As}, \mathrm{CuI} \text {, } \\
\mathrm{NMP}\end{array}$ & 80 & 23 \\
\hline 3 & OTf & $\mathrm{CO}_{2} \mathrm{Et}$ & 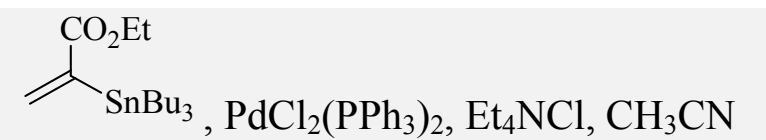 & 100 & 67 \\
\hline $4^{44}$ & OTf & $\mathrm{H}$ & 22, $\mathrm{Pd}(\mathrm{dba})_{2}, \mathrm{PPh}_{3}, \mathrm{~K}_{2} \mathrm{CO}_{3}, \mathrm{H}_{2} \mathrm{O} / \mathrm{DME}$ & 90 & 20 \\
\hline 5 & OTf & $\mathrm{H}$ & 22, $\mathrm{Pd}(\mathrm{dba})_{2} . \mathrm{PPh}_{3}, \mathrm{LiCl}, \mathrm{K}_{2} \mathrm{CO}_{3}, \mathrm{H}_{2} \mathrm{O} / \mathrm{DME}$ & 90 & 16 \\
\hline $6^{49}$ & $\mathrm{Cl}$ & $\mathrm{H}$ & 22, $\mathrm{Pd}(\mathrm{OAc})_{2}, \mathrm{CH}_{3} \mathrm{ONa}, \mathrm{CH}_{3} \mathrm{OH}$ & $\mathrm{rt}$ & 72 \\
\hline
\end{tabular}

Table 2. Stille and Suzuki coupling attempts

After the ineffective trials with the Stille and Suzuki coupling, we tried to obtain a methylpyrazine to perform a condensation with benzaldehyde. In an effort to obtain 2methyl-3-nitro-5,6-diphenylpyrazine, various routes were attempted. The first involved the procedure reported by Remennikov et al, which gave excellent results with pyrimidine. The second route, employing trimethyl aluminum, was described by Ohta and co-workers. ${ }^{50}$ Unfortunately, both methods failed to give the desired products (Scheme 42). 


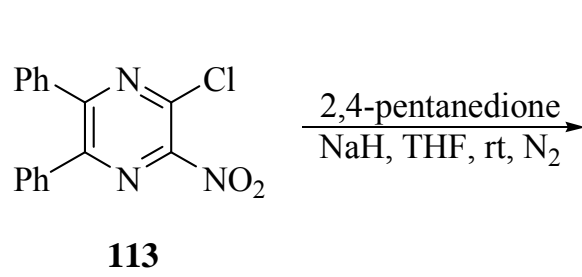

113<smiles>CC(=O)C(C(C)=O)c1nc(-c2ccccc2)c(-c2ccccc2)nc1[N+](=O)[O-]</smiles><smiles>C#C</smiles>

not observed<smiles>Cc1nc(-c2ccccc2)c(-c2ccccc2)nc1[N+](=O)[O-]</smiles><smiles>CCOC(=O)c1nc(-c2ccccc2)c(-c2ccccc2)nc1C</smiles>

not observed

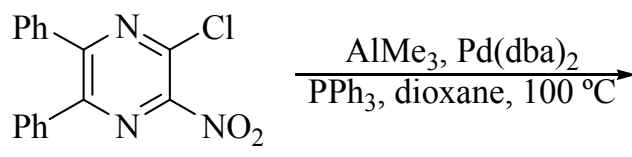

113

Scheme 42. Attempts towards a methyl pyrazine

In a different attempt, the methodology described by Guo ${ }^{51}$ was followed to obtain the desired 115 (Scheme 43). This compound was treated with fuming nitric acid and glacial acetic acid, but no nitration product was observed. Also, 115 was heated in a fuming nitric acid and concentrated sulfuric acid mixture. This attempt also failed to produce the desired nitrated product.

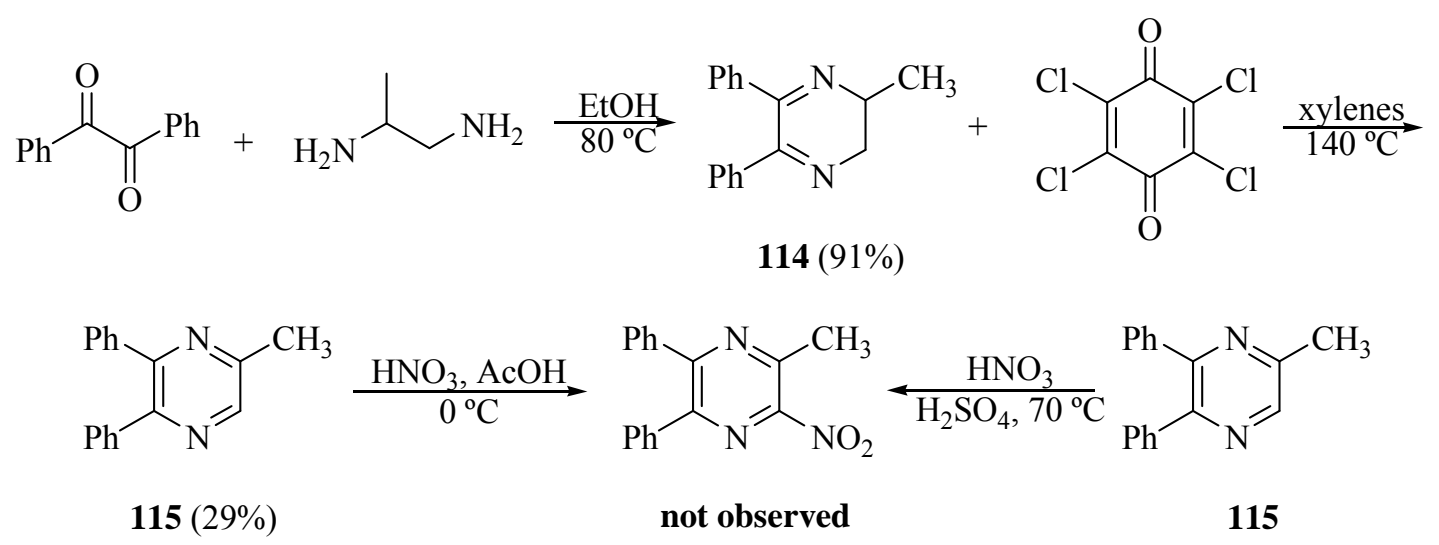

Scheme 43. Synthesis of 5-methyl-2,3-diphenylpyrazine 115

Our final attempts involved Sonogashira couplings between 112 or 113 and phenylacetylene or trimethylsilylacetylene. Table 3 shows the different conditions utilized in the Sonogashira reaction. 


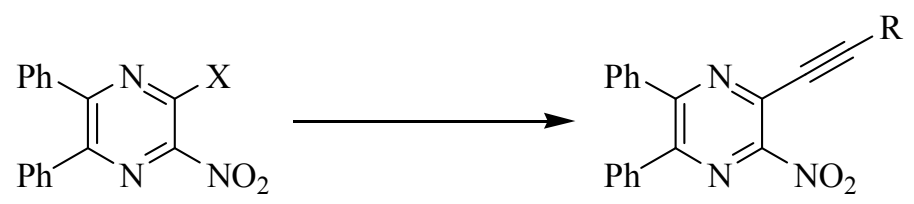

\begin{tabular}{|c|c|c|c|c|c|}
\hline Entry & $\mathbf{X}$ & $\mathbf{R}$ & Conditions & $\begin{array}{c}\text { Temp } \\
\left({ }^{\circ} \mathrm{C}\right)\end{array}$ & $\begin{array}{c}\text { Time } \\
\text { (h) }\end{array}$ \\
\hline 1 & OTf & $\mathrm{Ph}$ & $\begin{array}{l}\text { Phenylacetylene, } \mathrm{PdCl}_{2}\left(\mathrm{PPh}_{3}\right)_{2}, \mathrm{CuI}, \\
\mathrm{Et}_{3} \mathrm{~N} / \mathrm{THF}\end{array}$ & $\mathrm{rt}$ & 19 \\
\hline 2 & OTf & $\mathrm{Ph}$ & Phenylacetylene, $\mathrm{PdCl}_{2}\left(\mathrm{PPh}_{3}\right)_{2}, \mathrm{CuI}, \mathrm{NMP}$ & 50 & 87 \\
\hline 3 & OTf & $\mathrm{Ph}$ & $\begin{array}{l}\text { Phenylacetylene, } \mathrm{PdCl}_{2}\left(\mathrm{PPh}_{3}\right)_{2}, \mathrm{CuI}, \mathrm{Et}_{3} \mathrm{~N} \text {, } \\
\mathrm{N}_{2}\end{array}$ & 60 & 48 \\
\hline 4 & OTf & $\mathrm{Ph}$ & Phenylacetylene, $\mathrm{PdCl}_{2}\left(\mathrm{PPh}_{3}\right)_{2}, \mathrm{CuI}, \mathrm{Et}_{3} \mathrm{~N}$ & 70 & 91 \\
\hline 5 & $\mathrm{Cl}$ & $\mathrm{Ph}$ & Phenylacetylene, $\mathrm{PdCl}_{2}\left(\mathrm{PPh}_{3}\right)_{2}, \mathrm{CuI}, \mathrm{Et}_{3} \mathrm{~N}$ & $\mathrm{rt}$ & 22 \\
\hline 6 & $\mathrm{Cl}$ & $\mathrm{Ph}$ & Phenylacetylene, $\mathrm{PdCl}_{2}\left(\mathrm{PPh}_{3}\right)_{2}, \mathrm{CuI}, \mathrm{Et}_{3} \mathrm{~N}$ & 80 & 42 \\
\hline 7 & $\mathrm{Cl}$ & $\mathrm{Ph}$ & Phenylacetylene, $\mathrm{PdCl}_{2}\left(\mathrm{PPh}_{3}\right)_{2}, \mathrm{CuI}, \mathrm{Et}_{3} \mathrm{~N}$ & 70 & 92 \\
\hline 8 & OTf & TMS & $\begin{array}{l}\text { Trimethylsilylacetylene, } \mathrm{PdCl}_{2}\left(\mathrm{PPh}_{3}\right)_{2} \text {, } \\
\mathrm{CuI}, \mathrm{Et}_{3} \mathrm{~N}\end{array}$ & 90 & 23 \\
\hline 9 & OTf & TMS & $\begin{array}{l}\text { Trimethylsilylacetylene, } \mathrm{PdCl}_{2}\left(\mathrm{PPh}_{3}\right)_{2} \text {, } \\
\mathrm{CuI}_{2} \mathrm{Et}_{3} \mathrm{~N}\end{array}$ & 90 & 92 \\
\hline 10 & OTf & TMS & $\begin{array}{l}\text { Trimethylsilylacetylene, } \mathrm{PdCl}_{2}\left(\mathrm{PPh}_{3}\right)_{2} \text {, } \\
\mathrm{CuI}_{2} \mathrm{Et}_{3} \mathrm{~N}\end{array}$ & 90 & 180 \\
\hline 11 & OTf & TMS & $\begin{array}{l}\text { Trimethylsilylacetylene, } \mathrm{PdCl}_{2}\left(\mathrm{PPh}_{3}\right)_{2} \text {, } \\
\mathrm{CuI}_{2} \mathrm{Et}_{3} \mathrm{~N}\end{array}$ & 90 & 180 \\
\hline 12 & $\mathrm{Cl}$ & TMS & $\begin{array}{l}\text { Trimethylsilylacetylene, } \mathrm{PdCl}_{2}\left(\mathrm{PPh}_{3}\right)_{2} \text {, } \\
\mathrm{CuI}_{2} \mathrm{Et}_{3} \mathrm{~N}\end{array}$ & 90 & 22 \\
\hline
\end{tabular}

Table 3. Sonogashira coupling conditions

\section{Conclusion}

The methodology developed by the Söderberg group was successfully applied for the synthesis of various azaindoles and pyrrolodiazines. Total synthesis of 4-, 5-, 6-, and 7azaindoles (1-4) have been achieved using a condensation reaction with benzaldehyde or 
a Stille coupling followed by palladium-catalyzed reductive $N$-heteroannulation as the key step. Similarly, syntheses of $5 H$-pyrrolo[3,2-d]pyrimidine derivative (96)and $5 H$ pyrrolo[3,2-c]pyridazine derivative (105)have been achieved. The ability to synthesize certain compounds was severely impaired by the limited availability and/or the difficulty in preparing suitable starting materials. It can be concluded that the developed methodology will be successful in the synthesis of the remaining diazaindoles when adequate cyclization precursors become available either by viable commercial starting materials or by appropriate synthesis. 


\section{Part II}

\section{Synthesis of Carbazolones as an Advanced Intermediate to $(+)$-Aspidospermidine}

\section{Introduction}

Carbazole alkaloids have been of great interest due to their pharmacological potential and variety of biological activities. These natural products show properties such as antitumor, antifungal, antibiotic, as well as having inhibitory effects on mitosis and antimalarial activity. ${ }^{52}$ Most of these compounds have a one-carbon substituent in the 3-position and an oxygenated functionality in the 1- or 2- position. The Söderberg group has been interested in a number of these compounds, many of which are part are found in plants of the genus Murraya and Aspidosperma.

Carbazolones are carbazole derivatives that, like carbazole alkaloids, are interesting synthetic targets because of their biologically activity. Tetrahydrocarbazolones have been greatly used as advanced intermediates in synthetic efforts towards a number of naturally occurring carbazole alkaloids (Figure 3). A variety of methods have been used to prepare carbazolones. A common approach to the preparation of these types of compounds is via the Fischer indole synthesis. A Japp-Klingemann condensation of diazonium salts with 2-(hydroxymethylene)-1-cyclohexanones can be used to obtain hydrazones, which can be subjected to the Fischer indole synthesis to get the desired tetrahydrocarbazolone. ${ }^{53}$ The downside of this method is the highly acidic reaction 
conditions and regioisomeric product formation when asymmetrical or 3-substituted analogs are used.<smiles>O=C1C=CC(=O)c2c1[nH]c1ccccc21</smiles>

Murrayaquinone A<smiles>COc1cc(C)cc2c1[nH]c1ccccc12</smiles>

Murrayafoline A<smiles></smiles>

Dimeric $O$-demethylmurrayafoline A<smiles>COc1cc(C=O)cc2c1[nH]c1ccccc12</smiles>

Murrayanine<smiles>COc1ccc2c3c([nH]c2c1)C(=O)C=C(C)C3=O</smiles>

Koenigine-quinone A<smiles>CC[C@]12CCCCN3CC[C@]4(Nc5ccccc5N[C@H]4CC1)[C@@H]32</smiles>

$(+)$-Aspidospermidine

Figure 3. Carbazole alkaloids

Palladium-catalyzed Heck-type reactions (Scheme 44$)^{54}$ and arynic condensation of enaminones in the presence of $\mathrm{NaNH}_{2}-\mathrm{tBuONa}$ (Scheme 45$)^{55}$ have also been used to produce carbazolones.<smiles>CCNC1=CC(=O)CC(C)C1</smiles>

116<smiles>CCC1CC(=O)c2c([nH]c3ccccc23)C1</smiles>

$117(32 \%)$

Scheme 44. Formation of carbazolone derivative $\mathbf{1 1 7}$ 
<smiles>Cc1cccc(Br)c1NC1=CC(=O)CCC1</smiles>

118

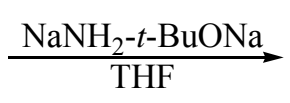<smiles>Cc1cccc2c3c([nH]c12)CCCC3=O</smiles>

119

Scheme 45. Preparation of carbazolone 119

(+)-Aspidospermidine (Figure 3), the parent compound of the Aspidosperma alkaloids, has been the fundamental target for most of the efforts regarding this family of compounds. This basic structure retains the characteristic pentacyclic skeleton, but is not of pharmacological relevance and contains no sensitive functional groups. This is the main reason why this compound is frequently used as a stepping stone for the development of new synthetic pathways that might aid in the construction of more complex Aspidosperma alkaloids. Among the pioneering methods developed for this purpose are the Stork's Fischer-indole, ${ }^{56}$ Harley-Mason's indoloquinolizidine rearrangement, ${ }^{57}$ Büchi's Diels-Alder, ${ }^{58}$ and Overman's aza-Cope rearrangement. More recent methodologies include the one published by Aubé and co-workers, ${ }^{59}$ featuring an intramolecular Schmidt reaction (Scheme 46). 


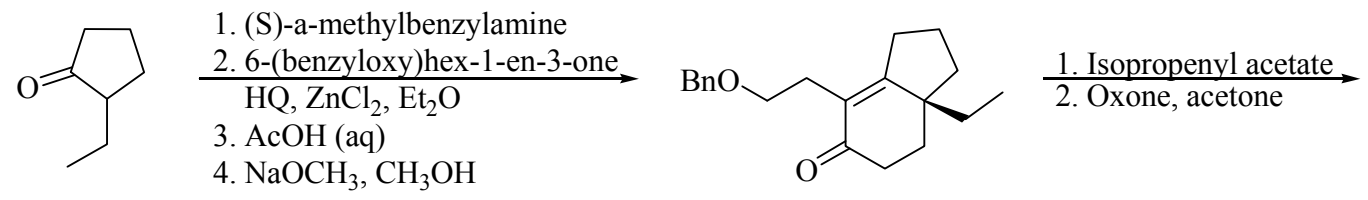

$120(49 \%)$

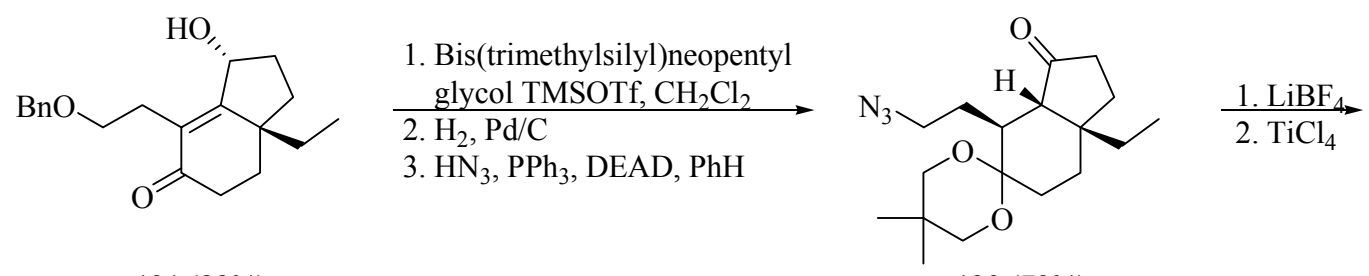

$121(88 \%)$

$122(73 \%)$<smiles>CC[C@]12CCC(=O)[C@@H]3CCN1C32</smiles>

$123(82 \%)$
1. Bis(trimethylsilyl)neopentyl glycol, TMSOTf, $\mathrm{CH}_{2} \mathrm{Cl}_{2}$

2. LAH, THF

3. $\mathrm{LiBF}_{4}, \mathrm{CH}_{3} \mathrm{CN}$ (aq)

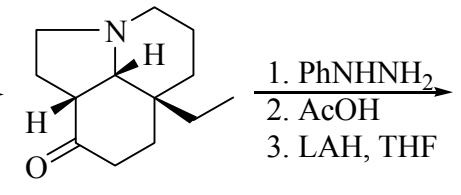

$124(67 \%)$

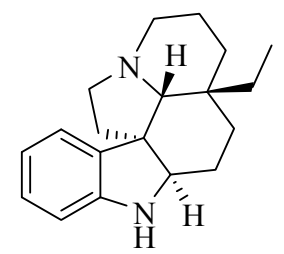

(+)-Aspidospermidine (51\%)

Scheme 46. Aubé's synthesis of (+)-Aspidospermidine

Another method recently developed was reported by Heathcock et al,${ }^{60}$ in which the key step is an intramolecular cascade reaction that simultaneously forms three rings (Scheme 47). Also, a short six-step synthesis (Scheme 48) was reported by Coldham and coworkers, ${ }^{61}$ in which three of the five rings are constructed in one step. ( \pm )-Aspidospermidine was obtained in $40 \%$ overall yield. 
<smiles>CCC1CCC(C(C)=O)C1=O</smiles>

125

$$
\begin{aligned}
& \text { 1. o-azidobenzyl bromide } \\
& \mathrm{Cs}_{2} \mathrm{CO}_{3} \text {, acetone } \\
& \text { 2. } \mathrm{Cs}_{2} \mathrm{CO}_{3}, t-\mathrm{BuOH} \\
& \text { acrylonitrile } \\
& \text { 3. } \mathrm{KOH}
\end{aligned}
$$

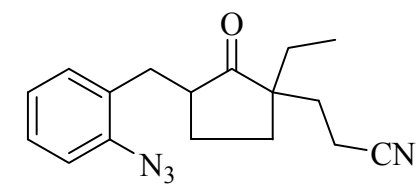

$126(77 \%)$
1. $\mathrm{CeCl}_{3} \cdot 7 \mathrm{H}_{2} \mathrm{O}$

$\mathrm{NaBH}_{4}, \mathrm{CH}_{3} \mathrm{OH}$

2. $\mathrm{PCl}_{5}$, pyridine

3. $\mathrm{LAH}$

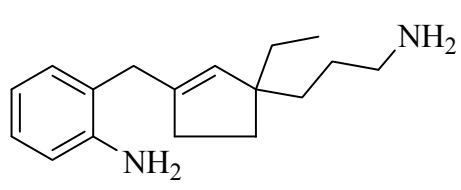

127 (65\%) $\frac{\text { 1. }\left(\mathrm{ClCH}_{2} \mathrm{CO}\right)_{2} \mathrm{O}, \mathrm{Et}_{3} \mathrm{~N}}{2 . \mathrm{Boc}_{2} \mathrm{O}, \mathrm{Et}_{3} \mathrm{~N}}$<smiles>CC/C(=C\C(CC)(CC)CCCNC(=O)CCl)Cc1ccccc1N</smiles>

$128(63 \%)$

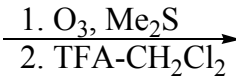

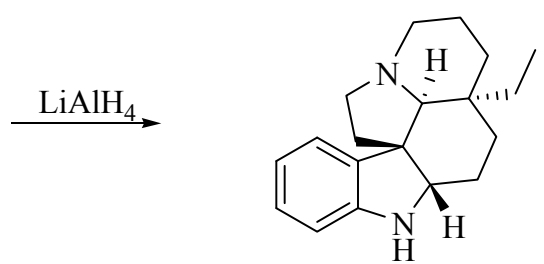<smiles>CC[C@]12CCCN(C(=O)CCl)[C@@H]1C1=Nc3ccccc3C1CC2</smiles>

$129(37 \%)$

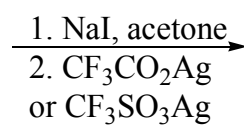
or $\mathrm{CF}_{3} \mathrm{SO}_{3} \mathrm{Ag}$<smiles>C[C@@]12C(=Nc3ccccc31)[C@@]1(C)C2CC[C@]23CCCC[C@]21C3</smiles>

$130(86 \%)$

( \pm -Aspidospermidine (82\%)

Scheme 47. Heathcock's synthesis of $( \pm)$-Aspidospermidine

While there are many methods for the preparation of carbazolones and carbazoles, these methods have some drawbacks. Some of the traditional methods lack regioselectivity and/or employ harsh conditions that may affect some functional groups. Another disadvantage is the availability of starting materials. Regioselectivity is not a problem in the method developed by the Söderberg group and numerous functional groups tolerate 
the milder reaction conditions. A new synthesis of tetrahydrocarbazolones used as advanced intermediates in the synthesis of (+)-Aspidospermidine is herein reported.

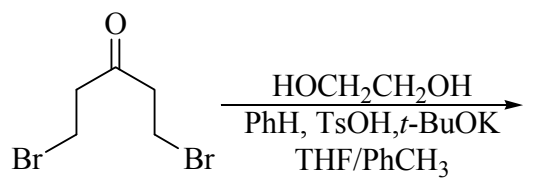

131
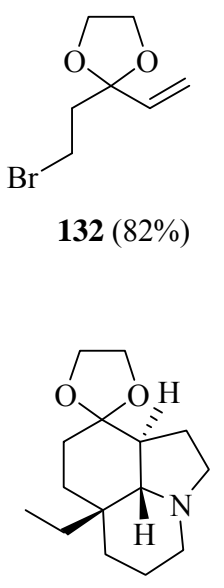

$135(79 \%)$

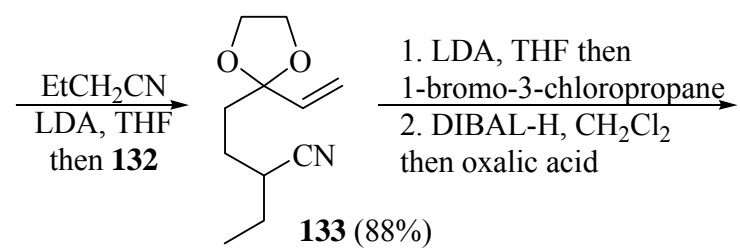

1. $\mathrm{HCl} / \mathrm{THF}$

$\underset{\text { 2. } \mathrm{PhNHNH}_{2}, \mathrm{PhH}}{\longrightarrow}$

3. $\mathrm{AcOH}$

4. LAH, THF

( \pm )-Aspidospermidine (42\%)

Scheme 48. Short synthesis of $( \pm)$-Aspidospermidine

\section{Results and Discussion}

Carbazolones could be prepared via the $N$-heteroannulation of 2-(2-nitrophenyl)-2-

cycloalkenones (Scheme 49), but it was necessary to develop a method to synthesize a variety of substituted 2-(2-nitrophenyl)-2-cycloalkenones.<smiles>[R2]C1CCc2[nH]c3cc[R1]([H])cc3c2C1=O</smiles>

Scheme 49. General synthetic strategy 
It was decided that the best route to obtain cyclization precursors was utilizing a Stille coupling reaction between cycloalkenones and nitrobenzenes (Scheme 50). This type of coupling, between 2-iodocycloalkenones and aryl stannanes using bis(benzonitrile)palladium dichloride $\left(\mathrm{PdCl}_{2}(\mathrm{PhCN})_{2}\right)$, triphenylarsine $\left(\mathrm{Ph}_{3} \mathrm{As}\right)$ and copper iodide $(\mathrm{CuI})$ in $N$-methylpyrrolidinone (NMP), was reported by Johnson et al. ${ }^{62}$ This methodology was successfully adapted by the Söderberg group to obtain a number of Stille coupling products. ${ }^{62}$ The coupling products could be easily cyclized to get the desired carbazolones in good yields.
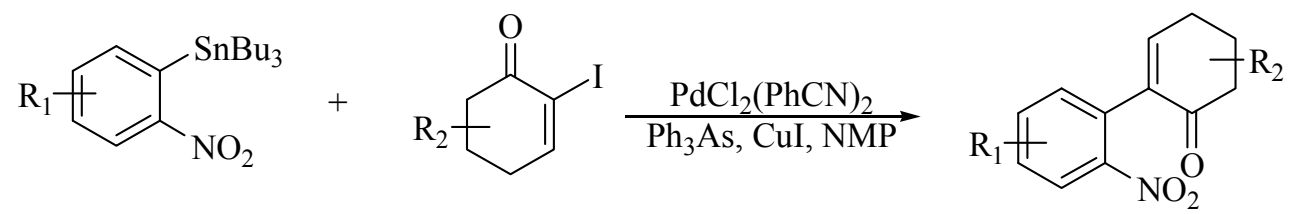

Scheme 50. General Stille coupling strategy

Efforts towards the synthesis of (+)-Aspidospermidine centered in obtaining 142. This key carbazolone intermediate was part of the synthesis reported by Desmaele and coworkers, as previously described. ${ }^{63}$ As shown in Scheme 51, with a slight modification of literature procedures, it was possible to obtain cyclohexenone $\mathbf{1 3 9}$ in good yield. This compound was treated with iodine and pyridine in carbon tetrachloride to get $\mathbf{1 4 0}$ in $\mathbf{7 3 \%}$ yield. Stille coupling between 140 and 141 was successfully accomplished utilizing the previously described conditions. 

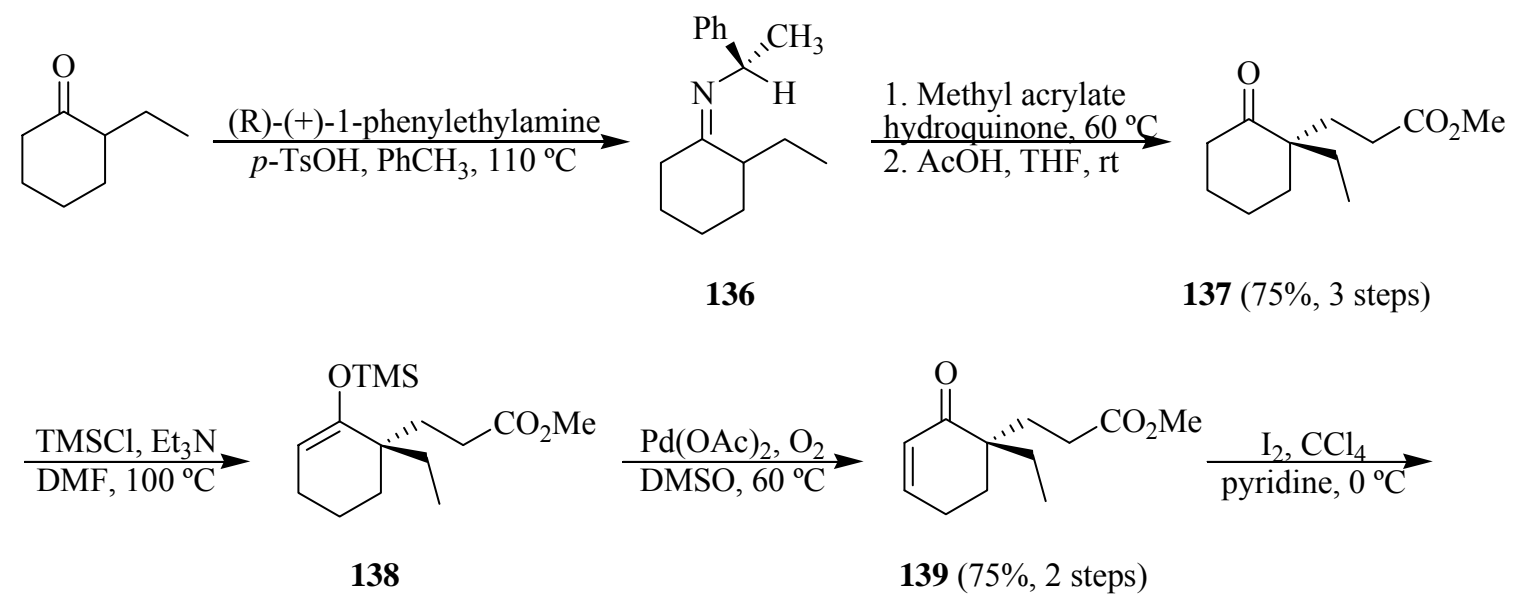

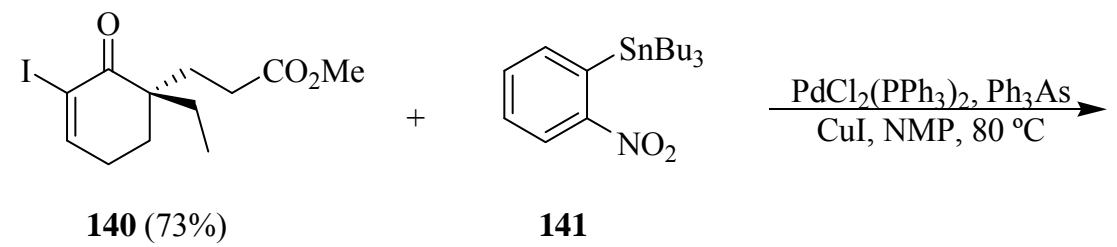
141<smiles>CC[C@]1(CCC(C)=O)CCC=C(c2ccccc2[N+](=O)[O-])C1=O</smiles><smiles>CCC12CCCN3CCC45c6ccccc6NC1CCC4(C3)C25</smiles>

$(+)$-Aspidospermidine

Scheme 51. Synthesis of carbazolone precursor 142

\section{Conclusion}

We have effectively applied the methodology to the synthesis of (+)-Aspidospermidine key intermediate 142. This methodology can be use as a stepping stone to obtain other compounds of the Aspidosperma family. The synthesis has been achieved using a Stille coupling reaction followed by a palladium-mediated reductive $N$-heteroannulation as the 
key steps. These new conditions provide a generally more efficient and higher yielding than previous methods utilized for the synthesis of these alkaloids. 


\section{Part III}

\section{Synthesis of Advanced Intermediates of Tetrahydrocarbazole Derivatives Via Palladium-Catalyzed Hydrogenation Reactions}

\section{Introduction}

$\mathrm{TiCl}_{3}$ reduction of compounds analogous to $\mathbf{1 4 3}$ has been reported by various groups. ${ }^{64}$ Reaction of 143 with aqueous $\mathrm{TiCl}_{3}$ in acetone gave1,2,3,4-tetrahydrocarbazole (144) in good yield, as shown in Scheme 52.

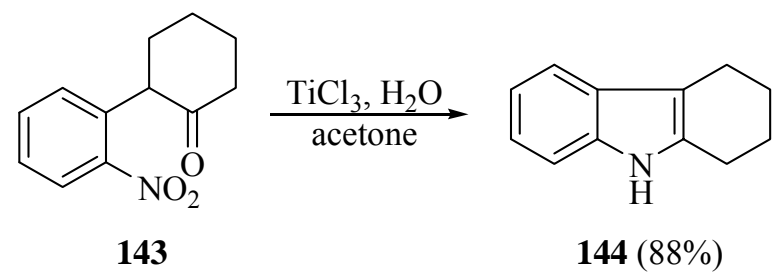

Scheme 52. Reduction with $\mathrm{TiCl}_{3}$

Other conventional methods used in the formation of carbazoles such as the Fischer indoles synthesis ${ }^{65}$ and palladium-catalyzed annulations between iodoanilines and ketones often suffer from a lack of regioselectivity and produce isomers (Scheme 53). 

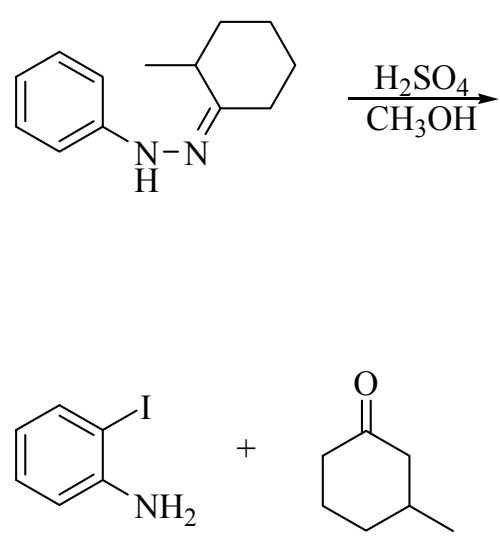<smiles>CC1CCCc2c1[nH]c1ccccc21</smiles>

145
$\underset{\mathrm{DMF}}{\stackrel{\mathrm{Pd}(\mathrm{OAc})_{2}}{\longrightarrow}}$<smiles>CC1CCCc2[nH]c3ccccc3c21</smiles>

$147(8 \%)$<smiles>CC12CCCCC1=Nc1ccccc12</smiles>

146

Scheme 53. Synthesis of methyl-substituted 1,2,3,4-tetrahydrocarbazoles

There is only one example in the literature reported by Tanaka and co-workers, ${ }^{66}$ in which a nitrobenzene and an $\alpha, \beta$-unsaturated ketone are successfully cyclized to the indole in the presence of $\mathrm{PtO}_{2}$ and hydrogen (Scheme 54).

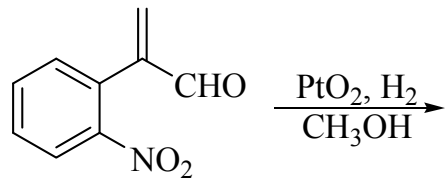<smiles>Cc1c[nH]c2ccccc12</smiles>

$149(40 \%)$

Scheme 54. Tanaka's indole synthesis of 149

In a study performed in the Söderberg group, it was discovered that it is possible to obtain 1,2,3,4-tetrahydrocarbazoles from direct reduction of the nitro group in 2-(2nitrophenyl)-2-cyclohexen-1-ones in the presence of $\mathrm{Pd} / \mathrm{C}$ and $1 \mathrm{~atm}$ of hydrogen (Scheme 55). The synthesis of advanced carbazole alkaloid intermediates via reductive cyclization is herein reported. 

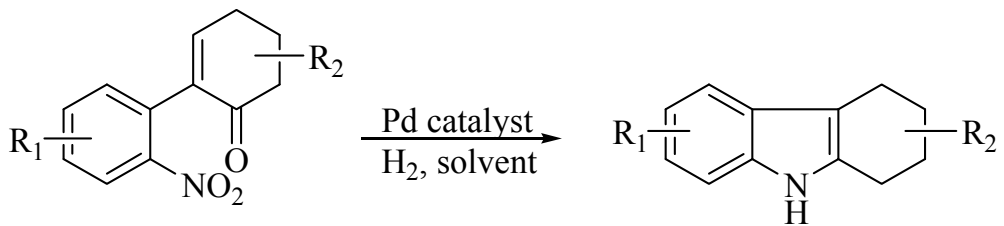

Scheme 55. General reductive cyclization

\section{Results and Discussion}

The synthesis of the advanced intermediate $\mathbf{1 5 2}$ was effectively accomplished (Scheme 56). Silylation of 4-methylcyclohexanone with trimethylsilyl chloride in the presence of triethylamine and DMF afforded $\mathbf{1 5 0}$ in excellent yield. This was followed by a palladium-catalyzed dehydrosilylation, Saegusa oxidation, ${ }^{67}$ to obtain 4 -methyl-2cyclohexen-1-one (151). A reason for the seemingly low yield might be the volatility of the compound. Iodination of $\mathbf{1 5 1}$ was accomplished in the presence of iodine and carbon tetrachloride in pyridine. This intermediate can be coupled with a nitroarene utilizing a Stille coupling or an Ullman-type coupling, similar to the one described by Banwell and co-workers. ${ }^{68}$ Finally, the coupling product can be submitted to a palladium-catalyzed reductive cyclization in the presence of $\mathrm{Pd} / \mathrm{C}$ and hydrogen $(1 \mathrm{~atm})$ to obtain the desired 3-methyl-1,2,3,4-tetrahydrocarbazole. 


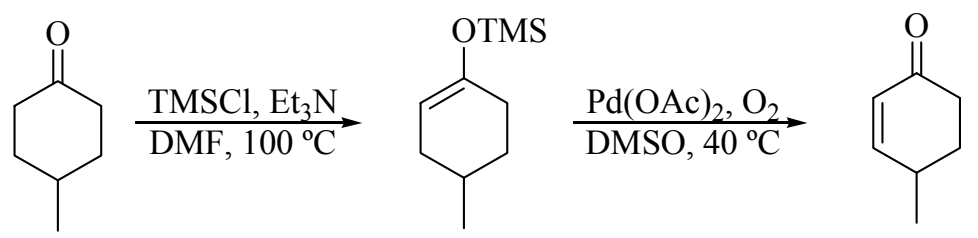

$150(95 \%)$

$151(42 \%)$
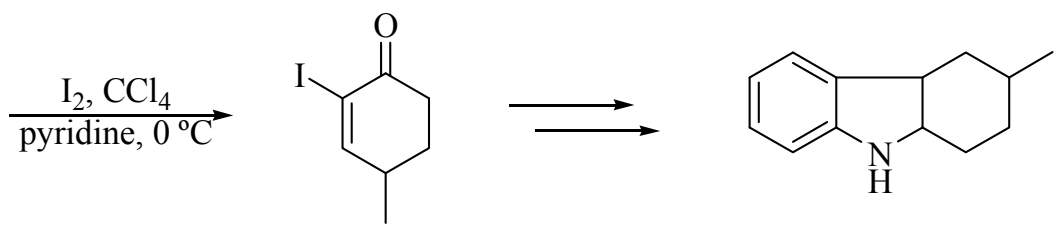

$152(51 \%)$

Scheme 56. Synthesis of advanced intermediate 152

As shown in Scheme 57, reaction of 2-cyclohexenone in the presence of iodine and carbon tetrachloride in pyridine afforded 153 in high yield. This was submitted to a palladium-mediated Ullman cross-coupling with o-bromonitrobenzene, to obtain the desired coupling product 154 in good yield. Instead of utilizing a palladium-catalyzed cyclization, it was decided to follow the $\mathrm{TiCl}_{3}$ cyclization procedure reported by Buchwald and co-workers. ${ }^{69}$ Treatment of 154 with $\mathrm{TiCl}_{3}$ in the presence of ammonium acetate in ethanol gave the carbazolone product 155 in low yield, the desired carbazole was not observed. This method was more successful for the synthesis of 2,3-substituted indoles than for the formation of tetrahydrocarbazole and tetrahydrocarbazolone 155. 

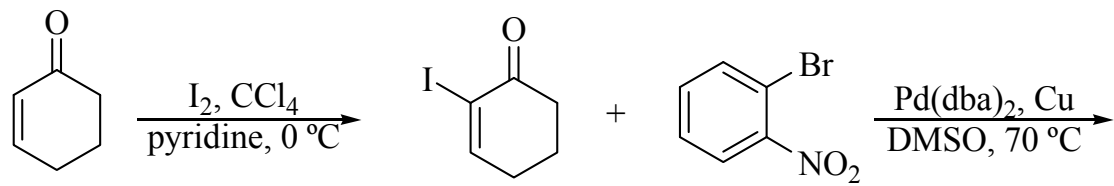

$153(65 \%)$<smiles>O=C1CCCC=C1c1ccccc1[N+](=O)[O-]</smiles>

$154(76 \%)$
$\underset{\mathrm{EtOH}, \mathrm{rt}}{\stackrel{\mathrm{TiCl}_{3}, \mathrm{NH}_{4} \mathrm{OAc}}{\longrightarrow}}$

$155(14 \%)$<smiles>c1ccc2c3c([nH]c2c1)CCCC3</smiles>

expected product not observed

Scheme 57. Synthesis of carbazolone 155

Synthesis of 8-methyl-1,2,3,4-tetrahydrocarbazole (161) started with commercially available 3-methyl-2-nitrobenzoic acid, which was treated with thionyl chloride to obtain the corresponding acid chloride, followed by addition of sodium azide afforded $\mathbf{1 5 6}$ (Scheme 58). This was heated in acetic acid to give 3-methyl-2-nitroaniline (157) in quantitative yield. A Sandmeyer reaction was performed to get 158 in 35\% yield. Conversion to aryl stannane 159 was achieved by reaction of 158 with hexabutylditin in the presence of $\mathrm{Pd}\left(\mathrm{PPh}_{3}\right)_{4}$, formed in situ, in toluene. Stille coupling between 153 and 159, using $\mathrm{PdCl}_{2}(\mathrm{PhCN})_{2}, \mathrm{Ph}_{3} \mathrm{As}$, and $\mathrm{CuI}$ in $\mathrm{NMP}$, gave 160 in $76 \%$ yield. Reductive cyclization of the coupling product was achieved using $\mathrm{Pd} / \mathrm{C}$ and hydrogen $(1 \mathrm{~atm})$ in methanol. Under these conditions we obtained 161 and 162, which indicates that the reduction of the cyclohexenone double bond occurs prior to the nitro group reduction. It has been demonstrated that submitting 162 to $\mathrm{Pd} / \mathrm{C}-\mathrm{H}_{2}$ conditions gives $161 .^{70}$ 


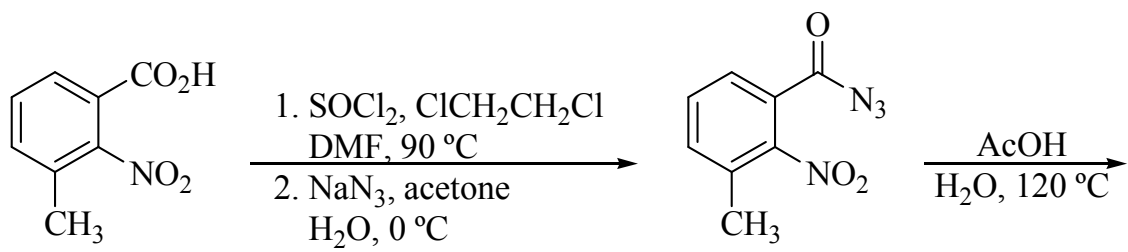

156

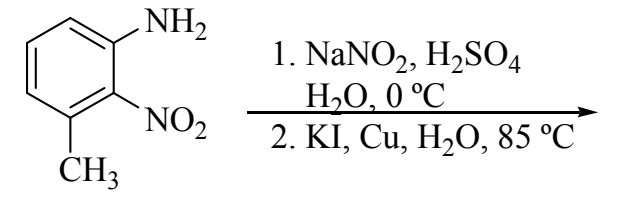

157 (99\%, 3 steps)

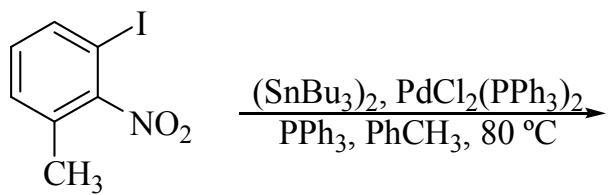

$158(35 \%)$

$\overbrace{\mathrm{CH}_{3}}^{\mathrm{NO}_{2}} \frac{153, \mathrm{PdCl}_{2}(\mathrm{PhCN})_{2}}{\mathrm{Ph}_{3} \mathrm{As}, \mathrm{CuI}, \mathrm{NMP}, 80^{\circ} \mathrm{C}}$

$159(75 \%)$<smiles>Cc1cccc(C2=CCCCC2=O)c1[N+](=O)[O-]</smiles>

$160(76 \%)$
$\frac{\mathrm{Pd} / \mathrm{C}, \mathrm{H}_{2}}{\mathrm{CH}_{3} \mathrm{OH}, \mathrm{rt}}$<smiles>Cc1cccc2c3c([nH]c12)CCCC3</smiles>

$161(36 \%)$<smiles>Cc1cccc(C2CCCCC2=O)c1[N+](=O)[O-]</smiles>

$162(43 \%)$

Scheme 58. Synthesis of carbazole 161

\section{Conclusion}

We have successfully developed a mild and efficient reaction pathway to carbazole

derivatives. The key steps in this route are two consecutive palladium-catalyzed reactions, a Stille coupling followed by reductive cyclization in the presence of palladium on carbon and $\mathrm{H}_{2}$. 


\section{Part IV}

\section{Experimental Section}

\section{General Procedures}

All NMR spectra were determined in $\mathrm{CDCl}_{3}$ at $600 \mathrm{MHz}\left({ }^{1} \mathrm{H} \mathrm{NMR}\right)$ and $150 \mathrm{MHz}\left({ }^{13} \mathrm{C}\right.$ NMR) unless otherwise stated. The chemical shifts are expressed in d values relative to $\mathrm{Me}_{4} \mathrm{Si}\left(0.00,{ }^{1} \mathrm{H}\right.$ and $\left.{ }^{13} \mathrm{C}\right)$ or $\mathrm{CDCl}_{3}\left(7.26,{ }^{1} \mathrm{H}\right.$ and $\left.77.00,{ }^{13} \mathrm{C}\right)$ internal standards. ${ }^{1} \mathrm{H}-{ }^{1} \mathrm{H}$ coupling constants are reported as calculated from spectra; thus, a slight difference between $J_{\mathrm{a}, \mathrm{b}}$ and $J_{\mathrm{b}, \mathrm{a}}$ is usually obtained. Results of APT (attached proton test) ${ }^{13} \mathrm{C}$ NMR experiments are shown in parenthesis, where relative to $\mathrm{CDCl}_{3},(-)$ denotes $\mathrm{CH}_{3}$ or $\mathrm{CH}$, and $(+)$ denotes $\mathrm{CH}_{2}$ or $\mathrm{C}$.

Tetrahydrofuran (THF), toluene, and diethyl ether were distilled from sodium benzophenone ketyl prior to use. Pyridine, triethylamine, hexanes, acetonitrile, diisopropylamine, and ethyl acetate were distilled from calcium hydride. Chemicals prepared according to literature procedures have been footnoted the first time they are used; all other reagents were obtained from commercial sources and used as received. All reactions were performed under nitrogen atmosphere in oven-dried glassware unless otherwise stated. Solvents were removed from reaction mixtures and products on a rotary evaporator at water aspirator pressure or by bulb-to-bulb distillation under reduced pressure. Chromatography was performed on silica gel 60 (35-75 mm, VWR). Melting points were determined on a MelTemp and are uncorrected. Elemental analyses were 
performed in the Department of Chemical Engineering, College of Engineering and Mineral Resources, West Virginia University.

\section{Experimental Details}

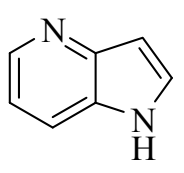

\section{H-pyrrolo[3,2-b]pyridine ${ }^{24}$ (1)}

To an oven-dried, threaded ACE glass pressure tube was added 3-nitro-2-vinylpyridine ${ }^{40}$ (84) (190 mg, $1.27 \mathrm{mmol}), \operatorname{Pd}(\mathrm{dba})_{2}(36.1 \mathrm{mg}, 0.0628 \mathrm{mmol}), 1,10$-phenanthroline (25.0 $\mathrm{mg}, 0.126 \mathrm{mmol})$, and anhydrous DMF $(4 \mathrm{~mL})$. The tube was fitted with a pressure head, the solution saturated with $\mathrm{CO}$ (four cycles to $6 \mathrm{~atm}$ ) and heated to $120^{\circ} \mathrm{C}(42 \mathrm{~h})$. The solvent was removed by bulb-to-bulb distillation under reduced pressure. The crude product was purified by flash chromatography (Hexanes/EtOAc, 3:7) to give $\mathbf{1}$ (97.6 mg, $0.826 \mathrm{mmol}, 65 \%$ ) as a light yellow solid. $\mathrm{mp} 126-128^{\circ} \mathrm{C}$ (Lit. $\left.125-126^{\circ} \mathrm{C}\right)$.

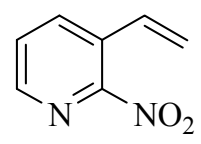

\section{2-nitro-3-vinylpyridine (86)}

A mixture of 2-nitro-3-trifluoromethanesulfonyloxypyridine ${ }^{24}$ (85) (507 mg, $1.86 \mathrm{mmol}$ ) vinyl tri-n-butyl stannane (700 mg, $2.21 \mathrm{mmol}$ ), tetraethylammonium chloride (305 mg, $1.84 \mathrm{mmol}), \mathrm{PdCl}_{2}\left(\mathrm{PPh}_{3}\right)_{2}(16.8 \mathrm{mg}, 0.0239 \mathrm{mmol})$ in $\mathrm{CH}_{3} \mathrm{CN}(10 \mathrm{~mL})$ was heated to reflux (67h). The mixture was diluted in $\mathrm{CHCl}_{3}(10 \mathrm{~mL})$ and $\mathrm{H}_{2} \mathrm{O}(10 \mathrm{~mL})$ and filtered 
through Celite. The filtrate was extracted with $\mathrm{CHCl}_{3}(30 \mathrm{~mL})$ and washed with $10 \%$ $\mathrm{NH}_{4} \mathrm{OH}(3 \times 15 \mathrm{~mL})$. The organic layer was dried $\left(\mathrm{MgSO}_{4}\right)$ and concentrated under vacuum. The crude was purified by flash chromatography (Hexanes/EtOAc, 8:2) to give 86 (236 mg, $1.57 \mathrm{mmol}, 85 \%)$ as a yellow solid. mp 34-36 ${ }^{\circ} \mathrm{C} .{ }^{1} \mathrm{H}$ NMR $\left(\mathrm{CDCl}_{3}, 600\right.$ MHz): $\delta 5.61(\mathrm{~d}, J=10.8 \mathrm{~Hz}, 1 \mathrm{H}), 5.86(\mathrm{~d}, J=17.4 \mathrm{~Hz}, 1 \mathrm{H}), 6.98(\mathrm{dd}, J=11.4,17.4 \mathrm{~Hz}$, 1H), $7.58(\mathrm{dd}, J=4.2,7.8 \mathrm{~Hz}, 1 \mathrm{H}), 8.09(\mathrm{dd}, J=1.8,7.8 \mathrm{~Hz}, 1 \mathrm{H}), 8.46(\mathrm{dd}, J=1.8,4.8$ $\mathrm{Hz}, 1 \mathrm{H}) .{ }^{13} \mathrm{C} \mathrm{NMR}\left(\mathrm{CDCl}_{3}, 150 \mathrm{MHz}\right): \delta 121.2(+), 126.9(+), 127.7(-), 129.5(-), 137.6(-)$, 147.5(-). IR (neat) $1531 \mathrm{~cm}^{-1}$. Anal. Calcd for $\mathrm{C}_{7} \mathrm{H}_{6} \mathrm{~N}_{2} \mathrm{O}_{2}: \mathrm{C}, 56.00 ; \mathrm{H}, 4.03$. Found: $\mathrm{C}$, 56.28; H: 4.23 .

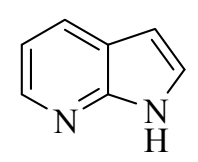

\section{$1 H$-pyrrolo[2,3-b]pyridine ${ }^{2}$ (4)}

Reaction of 2-nitro-3-vinylpyridine (86) (506 mg, $3.37 \mathrm{mmol})$ in the presence of $\mathrm{Pd}(\mathrm{dba})_{2}$ (95.8 mg, $0.167 \mathrm{mmol}), 1,10$-phenanthroline (67.1 mg, $0.338 \mathrm{mmol})$, and DMF (4 mL), as described for 1 (7.5d), gave, after chromatography (EtOAc/MeOH, 9:1), 4 (163 mg, $1.38 \mathrm{mmol}, 41 \%$ ) as a light yellow solid. mp $103-104^{\circ} \mathrm{C}\left(\right.$ Lit. $\left.105-106^{\circ} \mathrm{C}\right)$.

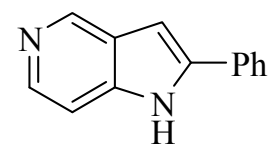

\section{2-phenyl-1H-pyrrolo[3,2-c]pyridine ${ }^{1}$ (89)}

A mixture of 4-nitro-3-styrylpyridine $\mathrm{N}$-oxide ${ }^{71}$ (88) $(102 \mathrm{mg}, 0.421 \mathrm{mmol})$ in the presence of $\mathrm{Pd}(\mathrm{dba})_{2}(11.5 \mathrm{mg}, 0.0200 \mathrm{mmol}), 1,10$-phenanthroline $(8.3 \mathrm{mg}, 0.042$ 
mmol), and anhydrous DMF (5 mL), was heated to $120^{\circ} \mathrm{C}(22 \mathrm{~h})$ as described for 1 . The crude product was purified by flash chromatography (EtOAc) to give $\mathbf{8 9}$ (74.4 $\mathrm{mg}, 0.383$ mmol, 91\%) as yellow crystals. mp $282-283{ }^{\circ} \mathrm{C}\left(\right.$ Lit. $\left.^{1} 282-283{ }^{\circ} \mathrm{C}\right)$.

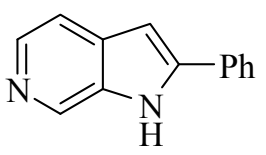

\section{2-phenyl-1H-pyrrolo[2,3-c]pyridine ${ }^{72}$ (91)}

Reaction of 3-nitro-4-styrylpyridine ${ }^{33}$ (90) $(131 \mathrm{mg}, 0.579 \mathrm{mmol})$ in the presence of $\operatorname{Pd}(\mathrm{dba})_{2}(16.6 \mathrm{mg}, 0.0289 \mathrm{mmol}), 1,10$-phenanthroline (11.6 mg, $\left.0.0585 \mathrm{mmol}\right)$, and anhydrous DMF (4 mL), as described for 1 (24h), gave, after chromatography (EtOAc/MeOH, 9:1) 91 (98.5 mg, $0.507 \mathrm{mmol}, 87 \%$ ) as a light yellow solid. mp 224$226^{\circ} \mathrm{C}$ (Lit. $\left.{ }^{1} 223-225^{\circ} \mathrm{C}\right)$.<smiles>CC(=O)C(C(C)=O)c1ncnc(Cl)c1[N+](=O)[O-]</smiles>

\section{4-acetylacetone-6-chloro-5-nitropyrimidine ${ }^{47}$ (93)}

To a suspension of $\mathrm{NaH}(104 \mathrm{mg}, 4.33 \mathrm{mmol})$ in anhydrous THF (10mL) under nitrogen, 2,4-pentanedione $(0.445 \mathrm{~mL}, 4.33 \mathrm{mmol})$ was added and stirred until all the $\mathrm{H}_{2}$ evolved (30 $\mathrm{min})$. 4,6-dichloro-5-nitropyrimidine ${ }^{73}$ (92) (500 $\mathrm{mg}, 2.58 \mathrm{mmol}$ ) was added and stirred under nitrogen (1h). An additional portion of $\mathrm{NaH}(62.0 \mathrm{mg}, 2.58 \mathrm{mmol})$ was added to the reaction mixture (3h). The THF was removed to give 93 (425 mg, 1.65 mmol, 64\%) as a light brown solid. mp $118-122{ }^{\circ} \mathrm{C}$ (Lit. ${ }^{47} 120-122{ }^{\circ} \mathrm{C}$ ). 


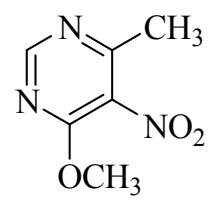

\section{4-methoxy-6-methyl-5-nitropyrimidine ${ }^{47}$ (94)}

A mixture of 4-acetylacetone-6-chloro-5-nitropyrimidine (93) (2.01 g, $7.80 \mathrm{mmol}), \mathrm{KOH}$ (875 mg, $15.6 \mathrm{mmol}$ ) in $\mathrm{CH}_{3} \mathrm{OH}(35 \mathrm{~mL}$ ) was heated to reflux (4h). The crude was purified by flash chromatography (Hexanes/EtOAc, 1:1) to give 94 (907 mg, $5.36 \mathrm{mmol}$, $69 \%$ ) as a light yellow solid. mp $75-76^{\circ} \mathrm{C}\left(\right.$ Lit. $\left.81-83^{\circ} \mathrm{C}\right)$.

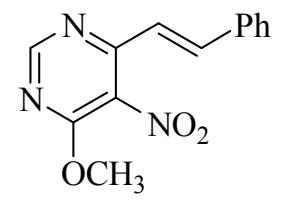

\section{4-methoxy-5-nitro-6-styrylpyrimidine (95)}

A mixture of 4-methoxy-6-methyl-5-nitropyrimidine (94) (163 mg, $0.964 \mathrm{mmol})$, benzaldehyde $(0.125 \mathrm{~mL}, 1.23 \mathrm{mmol})$, and piperidine $(0.050 \mathrm{ml}, 0.506 \mathrm{mmol})$ in $\mathrm{CH}_{3} \mathrm{OH}$ $(5 \mathrm{~mL})$ was heated to reflux $(15.5 \mathrm{~h})$. The precipitate was dissolved in acetone and purified by flash chromatography (Hexanes/EtOAc, 6:4) to give 95 (101 mg, 0.393

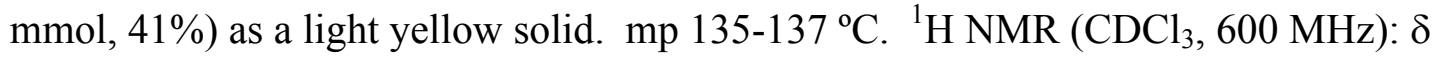
$4.12(\mathrm{~s}, 3 \mathrm{H}), 7.02(\mathrm{~d}, J=15.0 \mathrm{~Hz}, 1 \mathrm{H}), 7.39-7.42(\mathrm{~m}, 3 \mathrm{H}), 7.59$ (dd, $J=7.8,2.4 \mathrm{~Hz}, 2 \mathrm{H})$, $8.17(\mathrm{~d}, J=15.6 \mathrm{~Hz}, 1 \mathrm{H}), 8.74(\mathrm{~s}, 1 \mathrm{H}) ;{ }^{13} \mathrm{C} \mathrm{NMR}\left(\mathrm{CDCl}_{3}, 150 \mathrm{MHz}\right): \delta 55.3(-), 117.5$ (-), $128.3(-), 129.0(-), 130.4(-), 134.8(+), 142.1(-), 142.1(+), 154.2(+), 157.3(-)$, $161.4(+)$. IR (neat): $1637,1572,1521 \mathrm{~cm}^{-1}$. 
<smiles>COc1ncnc2cc(-c3ccccc3)[nH]c12</smiles>

\section{4-methoxy-6-phenyl-5H-pyrrolo[3,2-d]pyrimidine (96)}

Reaction of 4-methoxy-5-nitro-6-styrylpyrimidine (95) (251 mg, $0.976 \mathrm{mmol}), \mathrm{Pd}(\mathrm{dba})_{2}$ (27.7 mg, $0.0482 \mathrm{mmol}$ ) and 1,10-phenanthroline (19.3 $\mathrm{mg}, 0.973 \mathrm{mmol})$ in DMF (5 $\mathrm{mL}$ ), as described for $\mathbf{1}(24 \mathrm{~h})$, gave, after chromatography (Hexanes/EtOAc, 2:8; EtOAc; EtOAc/MeOH, 9:1; successively) 96 (180 mg, 0.799 mmol, 82\%) as a white solid. mp 222-223 ${ }^{\circ} \mathrm{C} .{ }^{1} \mathrm{H}$ NMR (DMSO-d $\left.6,600 \mathrm{MHz}\right): \delta 4.11(\mathrm{~s}, 3 \mathrm{H}), 7.05(\mathrm{~d}, J=1.8 \mathrm{~Hz}, 1 \mathrm{H})$, $7.40(\mathrm{t}, J=7.8 \mathrm{~Hz}, 1 \mathrm{H}), 7.49(\mathrm{t}, J=8.4 \mathrm{~Hz}, 2 \mathrm{H}), 8.01(\mathrm{dd}, J=9.0,1.2 \mathrm{~Hz}, 2 \mathrm{H}), 8.41(\mathrm{~s}$, 1H), 12.3 (br s, $1 \mathrm{H}) ;{ }^{13} \mathrm{C}$ NMR (DMSO-d $\left.6,150 \mathrm{MHz}\right): \delta 53.1(-), 99.3(-), 115.5(+)$, $126.1(-), 128.7(-), 128.9(-), 131.0(+), 142.4(+), 149.4(-), 150.8(+), 155.2(+)$. IR (neat): $2754,1624,1526,1457,1393,1345,1293,1120 \mathrm{~cm}^{-1}$. Anal. Calcd for $\mathrm{C}_{13} \mathrm{H}_{11} \mathrm{~N}_{3} \mathrm{O}: \mathrm{C}, 69.32 ; \mathrm{H}, 4$ 4.92. Found: C, 69.61; H, 5.19.

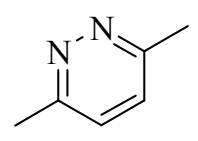

\section{3,6-dimethylpyridazine ${ }^{50,51}$ (101)}

To a solution of 2,5-dimethylfuran $(3.01 \mathrm{~g}, 31.3 \mathrm{mmol})$ in methanol $(150 \mathrm{~mL})$ at $0{ }^{\circ} \mathrm{C}$, hydrogen peroxide was added $(50 \%, 6.00 \mathrm{~mL}, 103 \mathrm{mmol})$. The solution was stirred and $\mathrm{NaOCl}(5 \%, 21 \mathrm{~mL}, 14.1 \mathrm{mmol})$ was slowly added and stirred (15 min). Hydrazine hydrate $(51 \%, 5.90 \mathrm{~mL}, 96.5 \mathrm{mmol})$ was added and allowed to warm up to room temperature. The methanol was removed under reduced pressure and the residue extracted with chloroform $(4 \times 75 \mathrm{~mL})$. The organic layer was washed with brine $(3 \times 45$ 
$\mathrm{mL})$, dried $\left(\mathrm{MgSO}_{4}\right)$ and concentrated to obtain $101(1.01 \mathrm{~g}, 9.34 \mathrm{mmol}, 67 \%)$ as a clear oil.

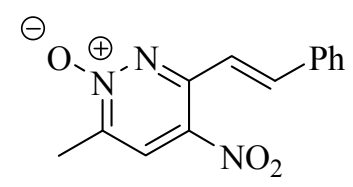

\section{6-methyl-4-nitro-3-styrylpyridazine 1-oxide (104)}

A solution of 3,6-dimethyl-4-nitropyridazine 1-oxide $(\mathbf{1 0 3})^{74}(123 \mathrm{mg}, 0.727 \mathrm{mmol})$, benzaldehyde (99.9 mg, $0.941 \mathrm{mmol})$, and piperidine ( $0.038 \mathrm{~mL}, 0.386 \mathrm{mmol})$ in $\mathrm{CH}_{3} \mathrm{OH}$ (4.0 mL) was heated to reflux (21h). The mixture was extracted with $\mathrm{CH}_{2} \mathrm{Cl}_{2}(3 \times 10$ $\mathrm{mL})$ and the organic layer was dried $\left(\mathrm{MgSO}_{4}\right)$ and concentrated under vacuum. After purification by flash chromatography (Hexanes/EtOAc, 6:4) 104 (56.5 mg, $0.220 \mathrm{mmol}$, $30 \%$ ) was obtained as a yellow solid. mp $170-172{ }^{\circ} \mathrm{C} .{ }^{1} \mathrm{H}$ NMR $\left(\mathrm{CDCl}_{3}-\mathrm{d}_{6}, 600 \mathrm{MHz}\right): \delta$ $2.56(\mathrm{~s}, 3 \mathrm{H}), 7.39-7.44(\mathrm{~m}, 3 \mathrm{H}), 7.63(\mathrm{dd}, J=7.8,1.8 \mathrm{~Hz}, 2 \mathrm{H}), 7.76(\mathrm{~d}, J=16.2 \mathrm{~Hz}, 1 \mathrm{H})$, $8.06(\mathrm{~d}, J=15.6 \mathrm{~Hz}, 1 \mathrm{H}), 8.25(\mathrm{~s}, 1 \mathrm{H}) ;{ }^{13} \mathrm{C} \mathrm{NMR}\left(\mathrm{CDCl}_{3}-\mathrm{d}_{6}, 150 \mathrm{MHz}\right): \delta 17.7(-)$, 116.7(-), 128.3(-), 129.0(-), 129.4(-), 130.3(-), 134.2(+), 135.1(-), 141.8(+), 143.1(+), 149.6(+). IR (neat): 3057, 2666, 1314, $1214 \mathrm{~cm}^{-1}$. Anal. Calcd for $\mathrm{C}_{13} \mathrm{H}_{11} \mathrm{~N}_{3} \mathrm{O}_{3}$ : C, 60.70; H, 4.31; N, 16.33. Found: C, 61.07; H, 4.68; N, 16.28. 


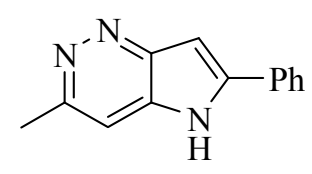

\section{6-methyl-2-phenyl-5H-pyrrolo[3,2-c]pyridazine (105)}

Reaction of 6-methyl-4-nitro-3-styrylpyridazine (104) (45.9 mg, $0.178 \mathrm{mmol}), \operatorname{Pd}(\mathrm{dba})_{2}$ (5.40 mg, $0.00939 \mathrm{mmol}$ ), and 1,10-phenanthroline (3.80 mg, $0.0192 \mathrm{mmol}$ ) in DMF (4 $\mathrm{mL}$ ), as described for $\mathbf{1}(14 \mathrm{~h})$, gave, after chromatography (EtOAc, followed by EtOAc/ $\mathrm{CH}_{3} \mathrm{OH}$, 9:1) 105 (22.8 $\left.\mathrm{mg}, 0.109 \mathrm{mmol}, 61 \%\right)$ as a yellow solid. $\mathrm{mp}>250{ }^{\circ} \mathrm{C}$. ${ }^{1} \mathrm{H}$ NMR (DMSO-d 6 , $\left.600 \mathrm{MHz}\right): \delta 2.45$ (s, 3H), $7.01(\mathrm{~s}, 1 \mathrm{H}), 7.44(\mathrm{t}, J=7.8 \mathrm{~Hz}, 1 \mathrm{H})$, $7.53(\mathrm{t}, J=7.8 \mathrm{~Hz}, 2 \mathrm{H}), 7.87$ (s, 1H), 7.95 (d, $J=7.2 \mathrm{~Hz}, 2 \mathrm{H}), 12.3$ (br s, $1 \mathrm{H}) ;{ }^{13} \mathrm{C} \mathrm{NMR}$ (DMSO-d $6,150 \mathrm{MHz}$ ): $\delta 18.6(-), 95.5(+), 115.4(-), 124.4(+), 125.8(-), 129.0(-)$, $129.1(-), 130.4(-), 137.4(+), 144.4(+), 146.1(+)$. IR (neat): 3057, 2666, 1314, 1214 $\mathrm{cm}^{-1}$.<smiles>CCOc1nc(-c2ccccc2)c(-c2ccccc2)nc1[N+](=O)[O-]</smiles>

\section{2-trifluoromethanesulfonyloxy-3-nitro-5,6-diphenylpyrazine (112)}

To a solution of 2-hydroxy-3-nitro-5,6-diphenylpyrazine ${ }^{56}(\mathbf{1 1 1})(1.89 \mathrm{~g}, 6.44 \mathrm{mmol})$ and $\mathrm{N}$,N-diisopropylethylamine $(3.20 \mathrm{~mL}, 18.4 \mathrm{mmol})$ in $\mathrm{CH}_{2} \mathrm{Cl}_{2}(100 \mathrm{~mL})$ at $0{ }^{\circ} \mathrm{C}$ under $\mathrm{N}_{2}$ atmosphere, trifluoromethanesulfonic anhydride $(1.52 \mathrm{~mL}, 9.05 \mathrm{mmol})$ was slowly added and stirred (3h). Cold water was added to the reaction mixture and extracted with $\mathrm{CH}_{2} \mathrm{Cl}_{2}$ $(3 \times 50 \mathrm{~mL})$. The organic layer was dried $\left(\mathrm{MgSO}_{4}\right)$ and concentrated under vacuum. The crude was purified by flash chromatography (Hexanes/EtOAc, 9:1) to give 112 (2.70 g, $6.35 \mathrm{mmol}, 98 \%)$ as a light yellow solid. mp 112-114 ${ }^{\circ} \mathrm{C} .{ }^{1} \mathrm{H} \mathrm{NMR}\left(\mathrm{CDCl}_{3}, 600 \mathrm{MHz}\right): \delta$ 
7.35-7.39 (m, 4H), 7.44-7.48 (m, 2H), 7.53-7.56 (m, 4H); ${ }^{13} \mathrm{C} \mathrm{NMR}\left(\mathrm{CDCl}_{3}, 150 \mathrm{MHz}\right)$ :

$\delta 115.3(+), 117.4(+), 119.5(+), 121.7(+), 128.8(-), 128.9(-), 129.8(-), 129.9(-), 130.1$

$(-), 130.6(-), 131.3(-), 134.4(+), 134.7(+), 140.8(+), 141.2(+), 151.4(+), 155.6(+)$.

IR (neat): $1431,1209 \mathrm{~cm}^{-1}$.

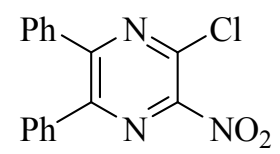

2-chloro-3-nitro-5,6-diphenylpyrazine (113)

A mixture of 2-hydroxy-3-nitro-5,6-diphenylpyrazine ${ }^{56}$ (111) $(251 \mathrm{mg}, 0.856 \mathrm{mmol})$, $\mathrm{N}, \mathrm{N}$-diethylaniline $(0.270 \mathrm{~mL}, 1.70 \mathrm{mmol})$, and phosphorus oxychloride $(5 \mathrm{~mL})$ was heated to reflux (4.5h). The reaction mixture was poured into ice and the precipitate filtered and washed with cold $\mathrm{H}_{2} \mathrm{O}$. Product 112 (264 mg, 0.847 mmol, 99\%) was obtained as a brown solid. No further purification was required. mp $167-168{ }^{\circ} \mathrm{C} .{ }^{1} \mathrm{H}$ $\operatorname{NMR}\left(\mathrm{CDCl}_{3}, 270 \mathrm{MHz}\right): \delta$ 7.25-7.46 (m, 8H).

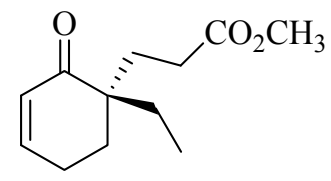

\section{Methyl (+)-(S)-1-ethyl-2-oxo-3-cyclohexene-1-propanoate (139) ${ }^{63}$}

To a solution of methyl (+)-(S)-1-ethyl-2-oxocyclohexane-1-propanoate ${ }^{63}$ (137) (2.89 g, $13.6 \mathrm{mmol})$ in anhydrous DMF $(25 \mathrm{~mL})$ was added $\mathrm{Et}_{3} \mathrm{~N}(10.0 \mathrm{~mL}, 71.7 \mathrm{mmol})$.

Trimethylsilyl chloride $(5.20 \mathrm{~mL}, 41.0 \mathrm{mmol})$ was slowly added and it was heated to 100 ${ }^{\circ} \mathrm{C}(72 \mathrm{~h})$. The reaction mixture was diluted with hexanes $(50 \mathrm{~mL})$ and poured into cold 
water $(50 \mathrm{~mL})$ and then extracted with hexanes. The combined organic layers were dried $\left(\mathrm{MgSO}_{4}\right)$ and concentrated under reduced pressure.

To the crude silyl enol ether (138) (3.45 g, $12.1 \mathrm{mmol})$ in DMSO (50 mL) was added $\mathrm{Pd}(\mathrm{OAc})_{2}(466 \mathrm{mg}, 2.08 \mathrm{mmol})$. The reaction was flushed and kept under oxygen (1 atm) while being heated to $40^{\circ} \mathrm{C}(72 \mathrm{~h})$. An additional portion of $\mathrm{Pd}(\mathrm{OAc})_{2}(285 \mathrm{mg}$, $1.27 \mathrm{mmol})$ was added and heated to $60^{\circ} \mathrm{C}(25 \mathrm{~h})$. The reaction mixture was cooled and diluted with ethyl acetate $(150 \mathrm{~mL})$ and washed with water $(3 \times 50 \mathrm{~mL})$. The combined organic layers were dried $\left(\mathrm{MgSO}_{4}\right)$ and concentrated. The crude was purified by flash chromatography (Hexanes/EtOAc, 7:3) to give 139 (1.92 g, $9.13 \mathrm{mmol}, 75 \%)$ as a colorless oil.

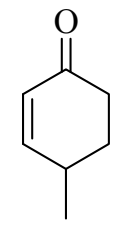

\section{4-methyl-2-cyclohexen-1-one $(151)^{75}$}

To a solution of $150(1.54 \mathrm{~g}, 8.35 \mathrm{mmol})$ in DMSO $(50 \mathrm{~mL})$ was added $\mathrm{Pd}(\mathrm{OAc})_{2}(181$ $\mathrm{mg}, 0.806 \mathrm{mmol})$. The reaction was flushed and kept under oxygen (1 atm) while being heated to $40{ }^{\circ} \mathrm{C}(24 \mathrm{~h})$. The reaction mixture was cooled and diluted with ethyl acetate $(100 \mathrm{~mL})$ and washed with water $(3 \times 40 \mathrm{~mL})$. The combined organic layers were dried $\left(\mathrm{MgSO}_{4}\right)$ and concentrated. The crude was purified by flash chromatography (Hexanes/EtOAc, 9:1) to afford 151 (382 mg, $3.47 \mathrm{mmol}, 42 \%$ ) as a colorless oil. 


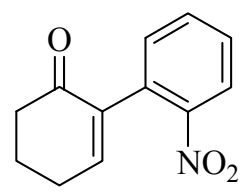

2-(2nitrophenyl)-2-cyclohexen-1-one (154) ${ }^{68}$

A solution of 2-iodo-2-cyclohexen-1-one $(\mathbf{1 5 3})^{76}(1.11 \mathrm{~g}, 5.00 \mathrm{mmol})$, o-bromonitrobenzene (2.02 g, $10.0 \mathrm{mmol}), \mathrm{Pd}(\mathrm{dba})_{2}(130 \mathrm{mg}, 0.226 \mathrm{mmol}), \mathrm{Cu}(1.57 \mathrm{~g}, 24.7 \mathrm{mmol})$ in DMSO $(17 \mathrm{~mL})$ was heated to $70^{\circ} \mathrm{C}(1.5 \mathrm{~h})$ under nitrogen. The reaction mixture was diluted with ether $(150 \mathrm{~mL})$ and filtered through Celite. The filtrate was washed with brine $(2 \times 150 \mathrm{~mL})$ and $\mathrm{H}_{2} \mathrm{O}(1 \times 150 \mathrm{~mL})$. The organic phase was dried $\left(\mathrm{MgSO}_{4}\right)$ and concentrated at reduced pressure. The crude product was purified by flash chromatography (Hexanes/EtOAc, 9:1, 7:3, 1:1, successively) to give 154 (823 mg, 3.79 mmol, $76 \%$ ) as a yellow solid. mp $91-93{ }^{\circ} \mathrm{C}\left(\right.$ Lit. $\left.{ }^{68} 92-95^{\circ} \mathrm{C}\right)$. 


\section{References}

${ }^{1}$ Fisher, M. H.; Schwartzkopf, G.; Hoff, D. R. J. Med. Chem. 1972, 15, 1168-1171.

2 Allegretti, M.; Anacardio, R.; Cesta, M. C.; Curti, R.; Mantovanini, M.; Nano, G.; Topai, A.; Zampella, G. Org. Process Res. Dev 2003, 7, 209-213.

${ }^{3}$ Verbiscal, A. J. J. Med. Chem. 1972, 15, 149-152.

${ }^{4}$ Lee, M. S.; Yum, E. K. Bull. Korean Chem. Soc. 2002, 23, 535-536.

${ }^{5}$ Song, J. J.; Reeves, J. T.; Gallou, F.; Tan, Z.; Yee, N. K.; Senanayake, C. H. Chem. Soc. Rev. 2007, 36, 1120-1132.

${ }^{6}$ Cupps, T. L.; Wise, D. S.; Townsend, L. B. J. Org. Chem. 1983, 48, 1060-1064.

${ }^{7}$ Otmar, M.; Masojídková, M.; Buděšinský, M.; Holý, A. Tetrahedron 1998, 54, 2931 2940.

${ }^{8}$ Zhang, Y. L.; Zhang, L. R.; Yang, Z. J.; Min, J. M.; Zhang, L. H.; Lu, Y.; Gong, N. B.; Zheng, Q. T. Chinese Chem. Lett. 2001, 12, 391-394.

${ }^{9}$ Seela, F.; Zulauf, M.; Chen, S. F. Nucleosides \& Nucleotides 2000, 19, 237-251.

${ }^{10} \mathrm{Li}$, J. J. J. Org. Chem. 1999, 64, 8425-8427.

${ }^{11}$ Popowycz, F.; Mérour, J.Y.; Joseph, B. Tetrahedron 2007, 63, 8689-8707.

${ }^{12}$ Hands, D.; Bishop, B.; Cameron, M.; Edwards, J. S.; Cottrell, I. F.; Wright, S. H. B. Synthesis 1996, 7, 877-882.

${ }^{13}$ Willett, R. E. Advan. Heterocycl. Chem. 1968, 9, 27-105.

${ }^{14}$ Zhang, Z.; Yang, Z.; Meanwell, N. A.; Kadow, J. F.; Wang, T. J. Org. Chem. 2002, 67, 2345-2347.

${ }^{15}$ Roy, P. J.; Dufresne, C.; Lachance, N.; Leclerc, J. P; Boisvert, M.; Wang, Z.; Leblanc, Y. Synthesis 2005, 16, 2751-2757.

${ }^{16}$ Cottineau, B.; O’Shea, D. F. Tetrahedron 2007, 63, 10354-10362.

${ }^{17}$ McLaughlin, M.; Palucki, M.; Davies, I. W. Org. Lett. 2006, 8, 3307-3310.

${ }^{18}$ Kumar, V.; Dority, J. A.; Bacon, E. R.; Singh, B.; Lesher, G. Y. J. Org. Chem. 1992, 57, 6995-6998.

${ }^{19}$ Sakamoto, T.; Satoh, C.; Kondo, Y.; Yamanaka, H. Heterocycles 1992, 34, 2379-2384.

${ }^{20}$ Mettey, Y.; Gompel, M.; Thomas, V.; Garnier, M.; Leost, M.; Ceballos-Picot, I.; Noble, M.; Endicott, J.; Vierfond, J.; Meijer, L. J. Med. Chem. 2003, 46, 222-236.

${ }^{21}$ Hopkins, C. R; Collar, N. Tetrahedron Lett. 2005, 46, 1845-1848.

${ }^{22}$ Hopkins, C. R.; Collar, N. Tetrahedron Lett. 2004, 45, 8087-8090.

${ }^{23}$ Klutchko, S.; Hansen, H. V.; Meltzer, R. I. J. Org. Chem. 1965, 30, 3454-3457.

${ }^{24}$ Tumkevicius, S.; Susvilo, I.; Brukstus, A. Chem. Heterocycl. Comp. 2004, 40, 1335 1338.

${ }^{25}$ Tkachenko, Y. N.; Tsupak, E. B.; Pozharskii, A. F. Chem. Heterocycl. Comp. 2000, 36, 307-310.

${ }^{26}$ Grahner, B.; Winiwarter, S.; Lanzner, W.; Müller, C. E. J. Med. Chem. 1994, 37, 15261534.

${ }^{27}$ Senga, K.; Ichiba, M.; Nishigaki, S. J. Org. Chem. 1979, 22, 3830-3834.

${ }^{28}$ Cook, P. D.; Castle, R. N. J. Heterocyclic Chem. 1973, 10, 807-812.

${ }^{29}$ Harcken, C.; Ward, Y.; Thomson, D.; Riether, D. Synlett 2005, 20, 3121-3125.

${ }^{30}$ Söderberg, B. C. G.; Shriver, J. A. J. Org. Chem. 1997, 62, 5838-5845.

${ }^{31}$ Akazome, M.; Kondo, T.; Watanabe, Y. J. Org. Chem. 1994, 59, 3375-3380.

${ }^{32}$ Tollari, S.; Cenini, S.; Crotti, C.; Gianella, E. J. Mol. Catal. 1994, 87, 203-214. 
${ }^{33}$ Li, J.; Chen, S. H.; Li, X.; Niu, C.; Doyle, T. W. Tetrahedron 1998, 54, 393-400.

${ }^{34}$ Darabantu, M.; Boully, L.; Turck, A. Plé, N. Tetrahedron 2005, 61, 2897-2905.

${ }^{35}$ Schomaker, J. M.; Delia, T. J. J. Org. Chem. 2001, 66, 7125-7128.

${ }^{36}$ Tang, J.; Chang, J.; Deng, M. Synth. Commun. 2004, 34, 3773-3783.

${ }^{37}$ Kerins, F.; O’Shea, D. F. J. Org. Chem. 2002, 67, 4968-4971.

${ }^{38}$ Bakthavachalam, V.; d'Alarcao, M.; Leonard, N. J. J. Org. Chem. 1984, 49, 289-295.

${ }^{39}$ Kato, Y.; Okada, S.; Tomimoto, K.; Mase, T. Tetrahedron Lett. 2001, 42, 4849-4851.

${ }^{40}$ Remennikov, G. Y.; Cherkasov, V. M. Ukrainskii Khimicheskii Zhurnal 1985, 51, 313 316.

${ }^{41}$ Hideo, K.; Masaru, O.; Haruyuki, W.; Ichiro, I. Chem. Pharm. Bull. 1961, 9, $1017-$ 1020.

${ }^{42}$ Foote, C. S.; Wexler, S.; Ando, W.; Higgins, R. J. Am. Chem. Soc. 1968, 90, 975-981.

${ }^{43}$ Fariña, F.; Martin, M. V.; Paredes, M. C. Anales de Química 1981, 77, 213-217.

${ }^{44}$ Kaupp, G.; Naimi-Jamal, M. R. Eur. J. Org. Chem. 2002, 8, 1368-1373.

${ }^{45}$ Hartman, G. D.; Schwering, J. E. J. Het. Chem. 1983, 20, 947-950.

${ }^{46}$ Dewkar, G. K.; Nikalje, M. D.; Ali, I. S.; Paraskar, A. S.; Jagtap, H. S.; Sudalai, A. Angew. Chem. Int. Ed. 2001, 40, 405-408.

${ }^{47}$ Kaftory, M.; Shteiman, V.; Lavy, T.; Scheffer, J. R.; Yang, J.; Enkelmann, V. Eur. J. Org. Chem. 2005, 5, 847-853.

${ }^{48}$ Karmas, G.; Spoerri, P. E. J. Am. Chem. Soc. 1953, 75, 5517-5519.

${ }^{49}$ Deng, C. L.; Guo, S. M.; Xie, Y. X.; Li, J. H. Eur. J. Org. Chem. 2007, 9, 1457-1462.

${ }^{50}$ Ohta, A.; Inoue, A.; Watanabe, T. Heterocycles 1984, 22, 2317-2321.

${ }^{51}$ Zhang, G. L.; Liu, Z. H.; Guo, H. Q. Wuli Huaxue Xuebao 2003, 19, 889-891.

${ }^{52}$ Bringmann, G.; Tasler, S.; Endress, H.; Peters, K.; Peters, E. Synthesis 1998, 10, 1501 1505.

${ }^{53}$ Scott, T. L.; Yu, X.; Gorugantula, S. P.; Carrero-Martínez, G.; Söderberg, B. C. G. Tetrahedron 2006, 62, 10835-10842.

${ }^{54}$ Iida, H.; Yuasa, Y.; Kibayasi, C. J. Org. Chem. 1980, 45, 2938-2942.

${ }^{55}$ Ianelli, S.; Nardelli, M.; Belletti, D.; Caubere, C.; Caubere, P.; Jamart-Gregoire, B. Acta Cryst. 1994, C50, 1919-1922.

${ }^{56}$ Stork, G.; Dolfini, J. E. J. Am. Chem. Soc. 1963, 85, 2872-2873.

${ }^{57}$ Harley-Mason, J.; Kaplan, M. Chem. Comm. 1967, 18, 915-916.

${ }^{58}$ Büchi, G.; Matsumoto, K. E. J. Am. Chem. Soc. 1971, 93, 3299-3301.

${ }^{59}$ Iyengar, R.; Schildknegt, K.; Aubé, J. Org. Lett. 2000, 2, 1625-1627.

${ }^{60}$ Toczko, M. A.; Heathcock, C. H. J. Org. Chem. 2000, 65, 2642-2645.

${ }^{61}$ Coldham, I.; Burrell, A. J. M.; White, L. E.; Adams, H.; Oram, N. Angew. Chem. Int. Ed. 2007, 46, 6159-6162.

${ }^{62}$ Johnson, C. R.; Adams, J. P.; Braun, M. P.; Senanayake, C. B. W. Tetrahedron Lett. 1992, 33, 919-922.

${ }^{63}$ Desmaele, D.; d'Angelo, J. J. Org. Chem. 1994, 59, 2292-2303.

${ }^{64}$ i) Iwama, T.; Birman, V. B.; Kozmin, S. A.; Rawal, V. H. Org. Lett. 1999, 1, 673-676.

ii) Moody, C. J.; Rahimtoola, K. F. J. Chem. Soc., Perkin Trans. 1 1990, 673-679. iii)

Ho, T. L.; Wong, C. M. Synthesis 1974, 45.

65 i) Stoermer, D.; Heathcock, C. H. J. Org. Chem. 1993, 58, 564-568. ii) Miller, F. M.; Schinske, W. N. J. Org. Chem. 1978, 43, 3384-3388.

${ }^{66}$ Tanaka, H.; Murakami, Y.; Torii, S. Bull. Chem. Soc. Jpn. 1989, 62, 4061-4062. 
${ }^{67}$ RajanBabu, T. V.; Chenard, B. L.; Petti, M. A. J. Org. Chem. 1986, 51, 1704-1712.

${ }^{68}$ Banwell, M. G.; Kelly, B. D.; Kokas, O. J.; Lupton, D. W. Org. Lett. 2003, 5, $2497-$ 2500.

${ }^{69}$ Rutherford, J. L.; Rainka, M. P.; Buchwald, S. L. J. Am. Chem. Soc. 2002, 124, 1516815169.

${ }^{70}$ Scott, T. L.; Burke, N.; Carrero-Martínez, G.; Söderberg, B. C. G. Tetrahedron 2007, 63, 1183-1190.

${ }^{71}$ Taylor, E. C.; Crovetti, A. J. J. Org. Chem. 1960, 25, 850-852.

72 Kuzmich, D.; Mulrooney, C. Synthesis 2003, 11, 1671-1678.

${ }^{73}$ Baindur, N.; Chadha, N.; Player, M. R. J. Comb. Chem. 2003, 5, 653-659.

${ }^{74}$ Itai, T.; Sako, S. Chem. Pharm. Bull. 1961, 9, 87-91.

${ }^{75}$ Chong, B. D.; Yong-Il, J.; Oh, S. S.; Yang, J. D.; Baik, W.; Koo, S. J. Org. Chem. 1997, 62, 9323-9325.

${ }^{76}$ Johnson, C. R.; Adams, J. P.; Braun, M. P.; Senanayake, C. B. W.; Wovkulich, P. M.; Uskokovish, M. R. Tetrahedron Lett. 1992, 33, 917-918. 
Appendix 


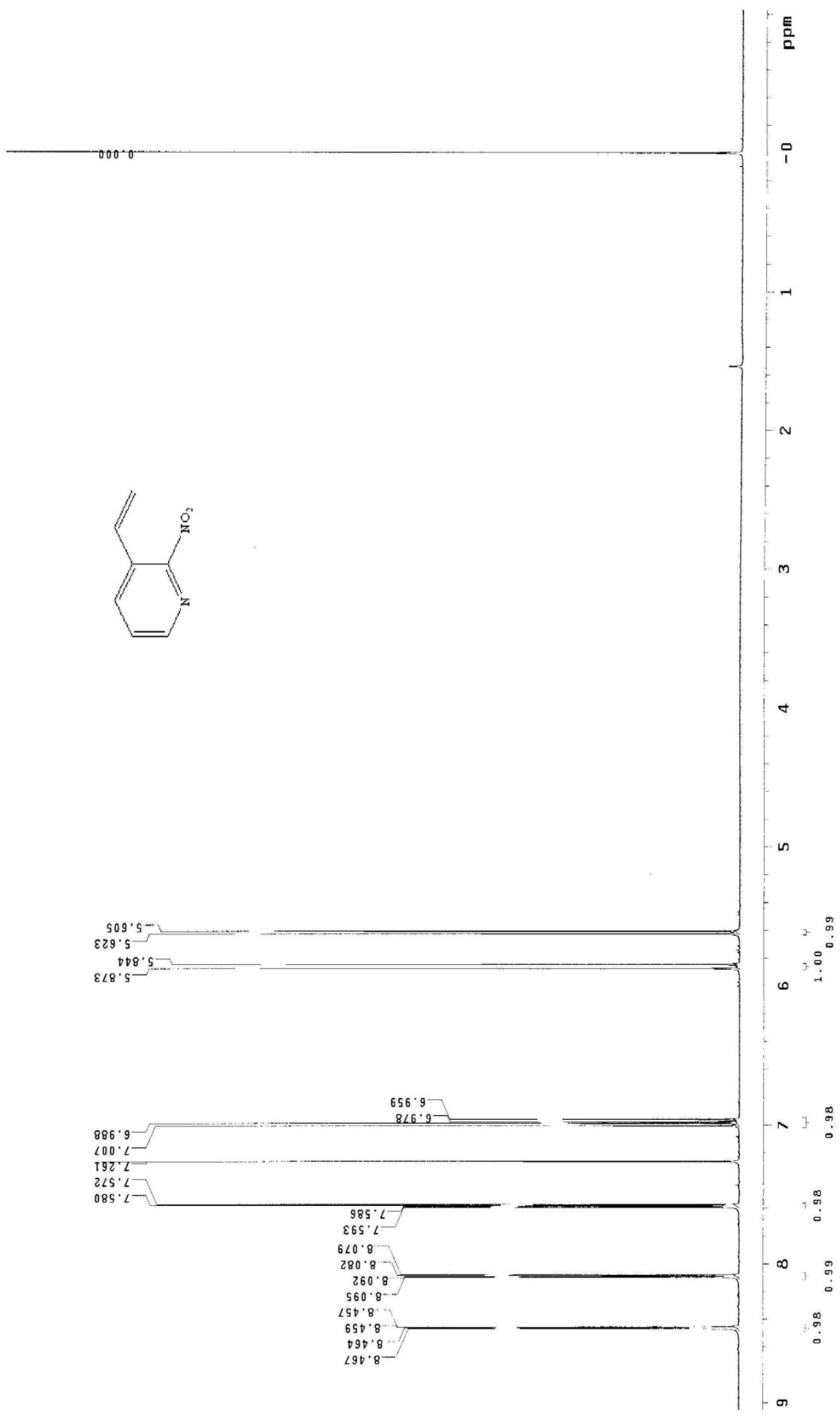


Figure 4: ${ }^{1} \mathrm{H}$ NMR of 2-nitro-3-vinylpyridine 86

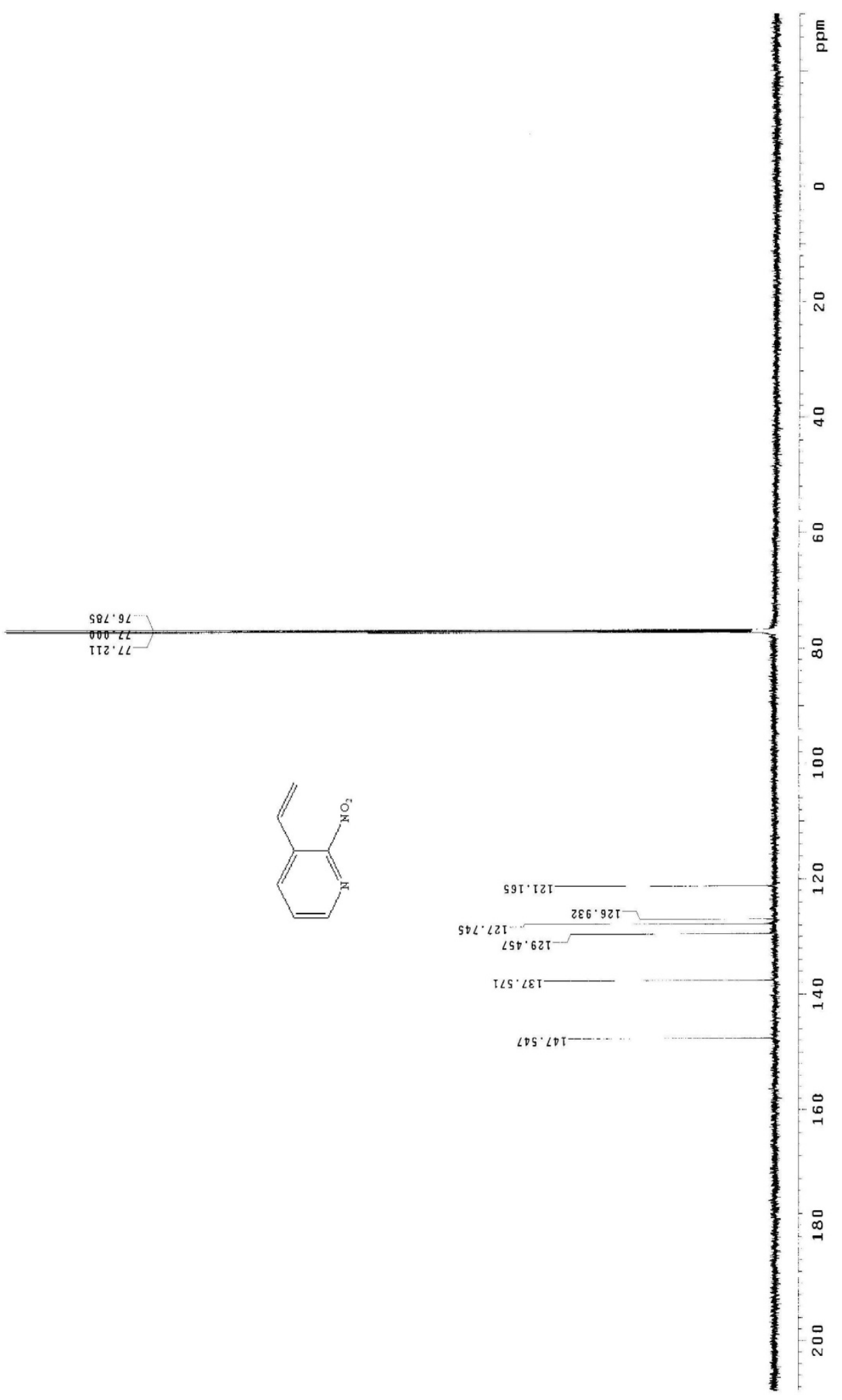


Figure 5: ${ }^{13} \mathrm{C}$ NMR of 2-nitro-3-vinylpyridine 86

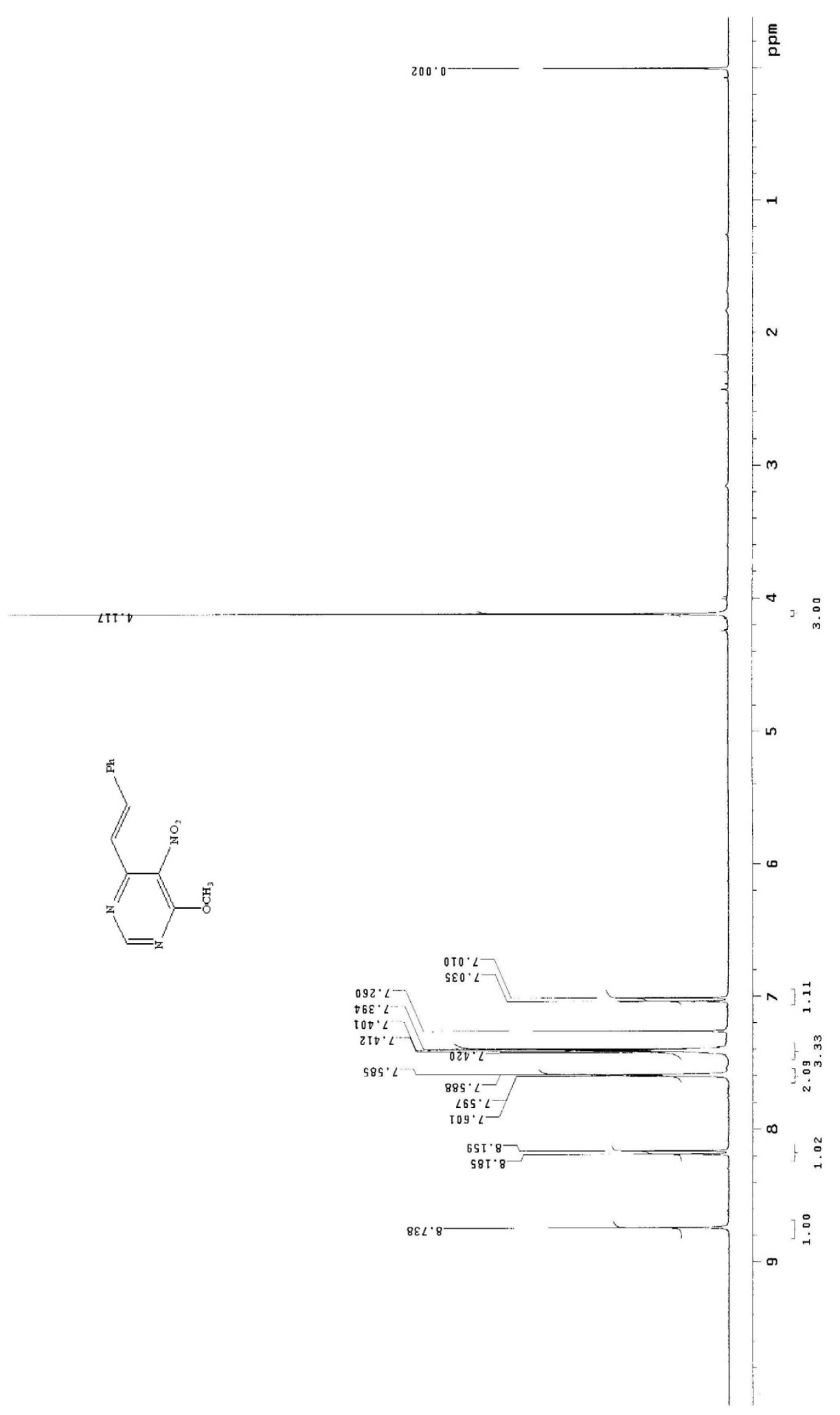


Figure 6: ${ }^{1} \mathrm{H}$ NMR of 4-methoxy-5-nitro-6-styrylpyrimidine 95

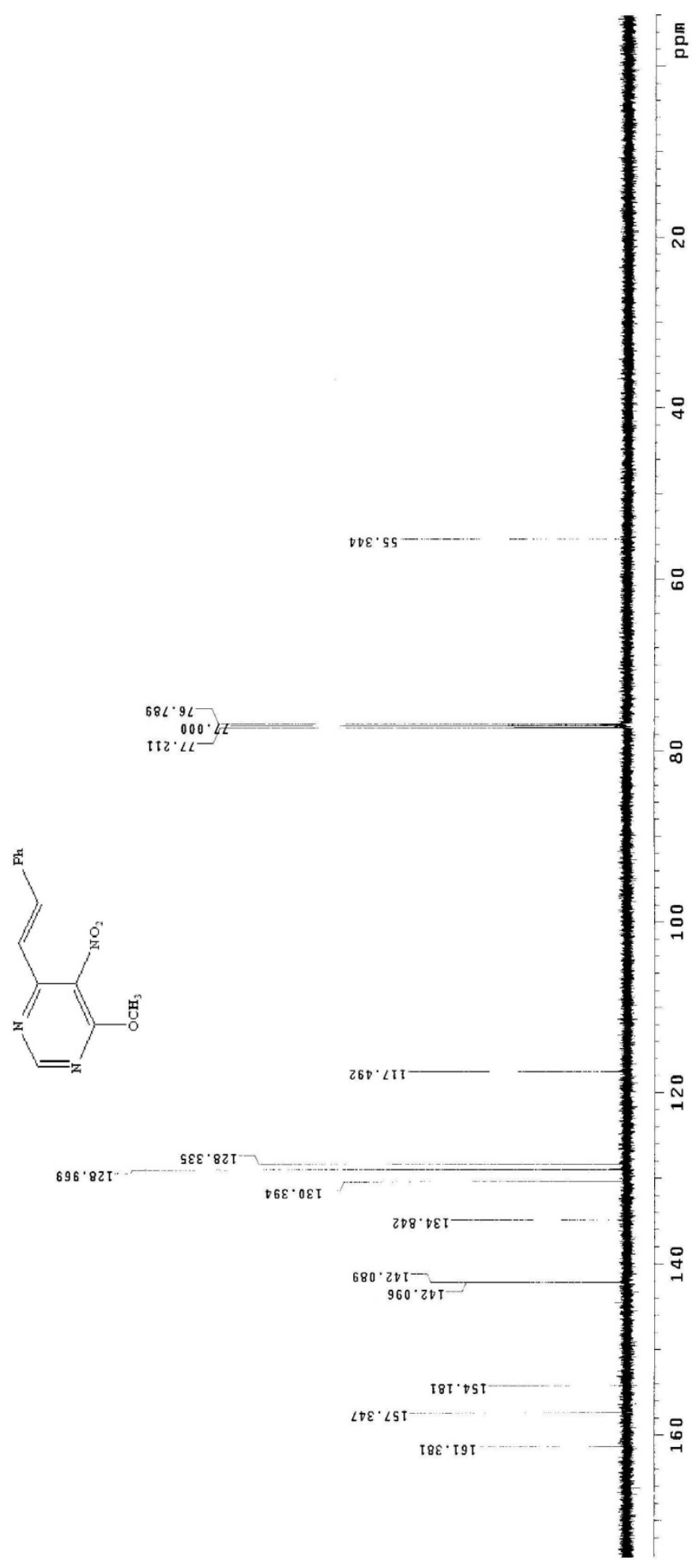


Figure 7: ${ }^{13} \mathrm{C}$ NMR of 4-methoxy-5-nitro-6-styrylpyrimidine 95

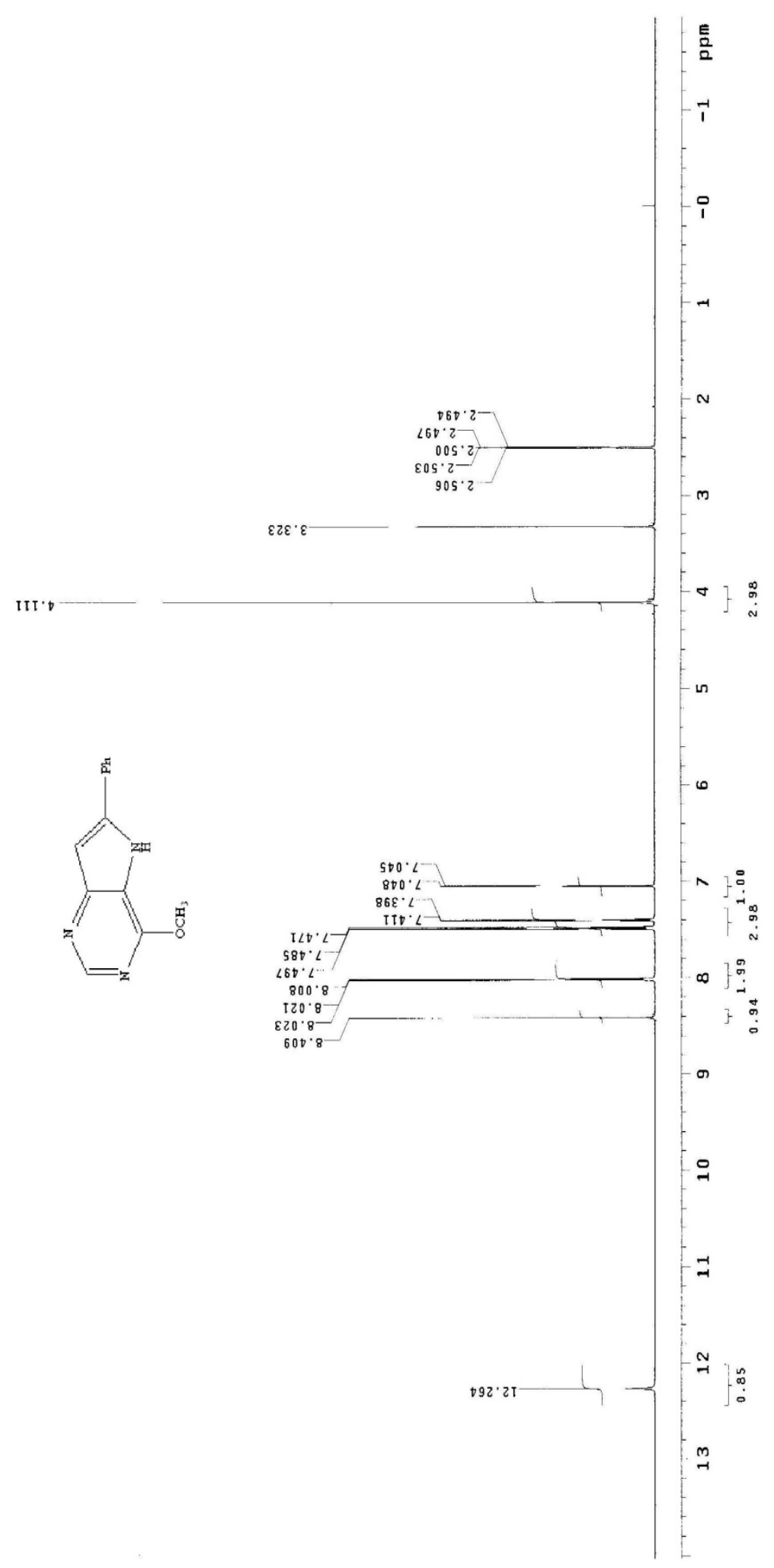


Figure 8: ${ }^{1} \mathrm{H}$ NMR of 4-methoxy-6-phenyl-5H-pyrrolo[3,2-d]pyrimidine 96

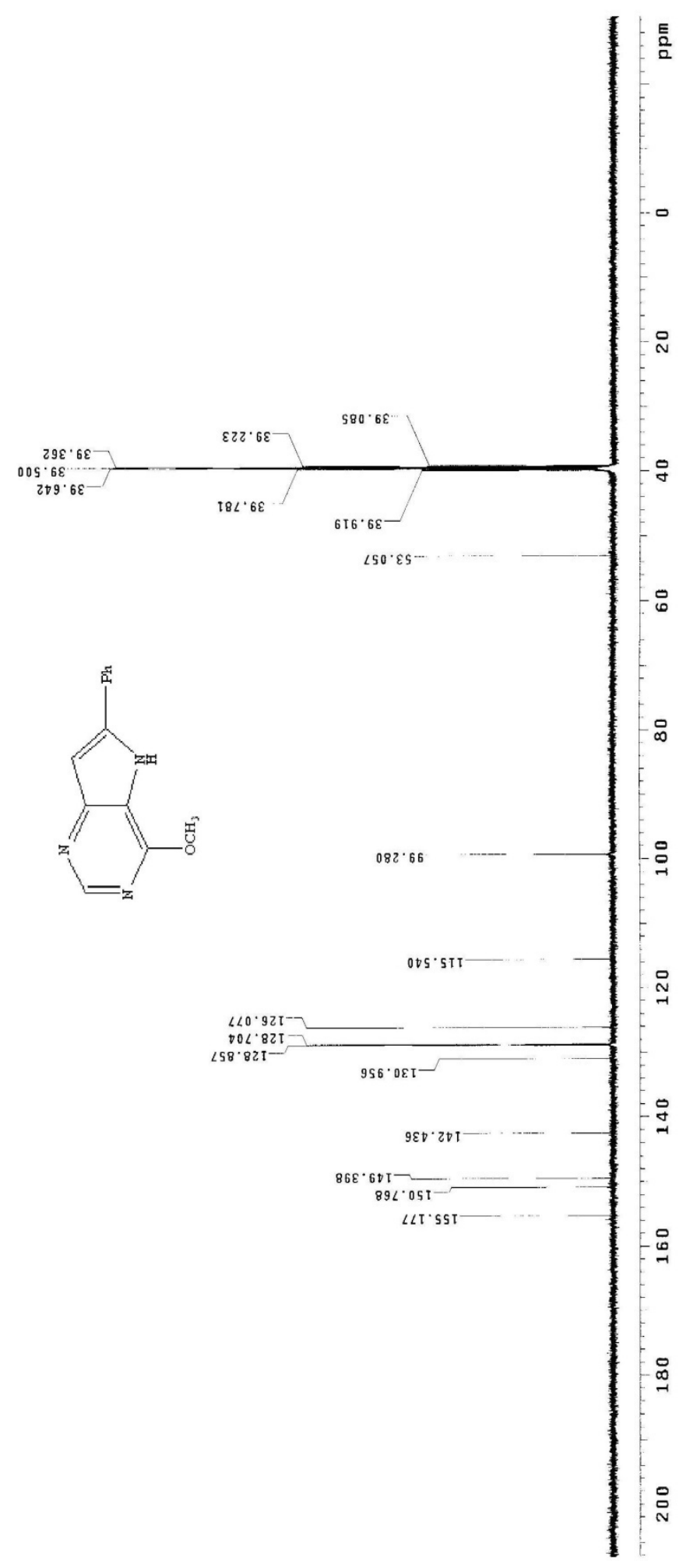


Figure 9: ${ }^{13} \mathrm{C}$ NMR of 4-methoxy-6-phenyl-5H-pyrrolo[3,2-d]pyrimidine 96

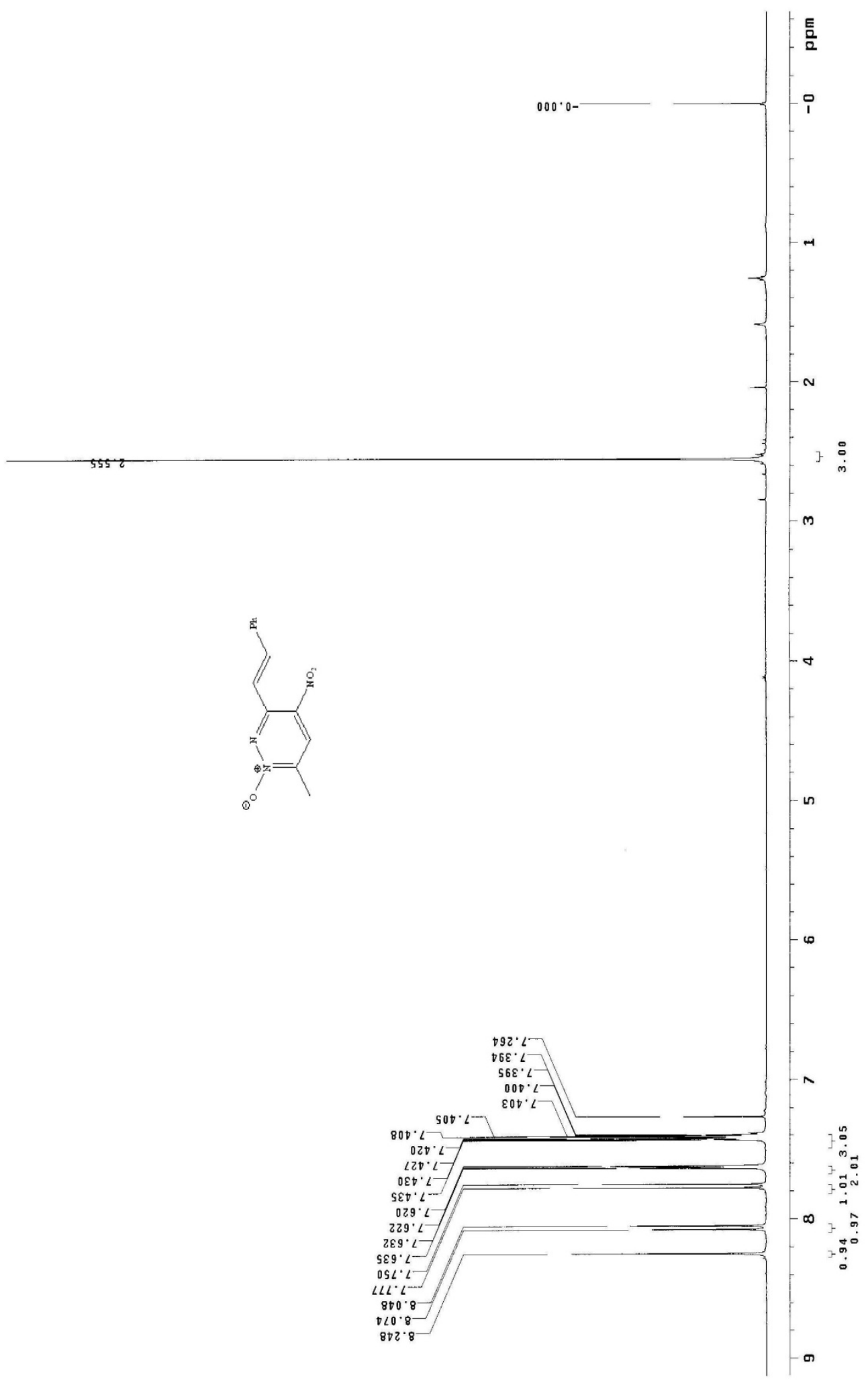


Figure 10: ${ }^{1} \mathrm{H}$ NMR of 6-methyl-4-nitro-3-styrylpyridazine 1-oxide 104

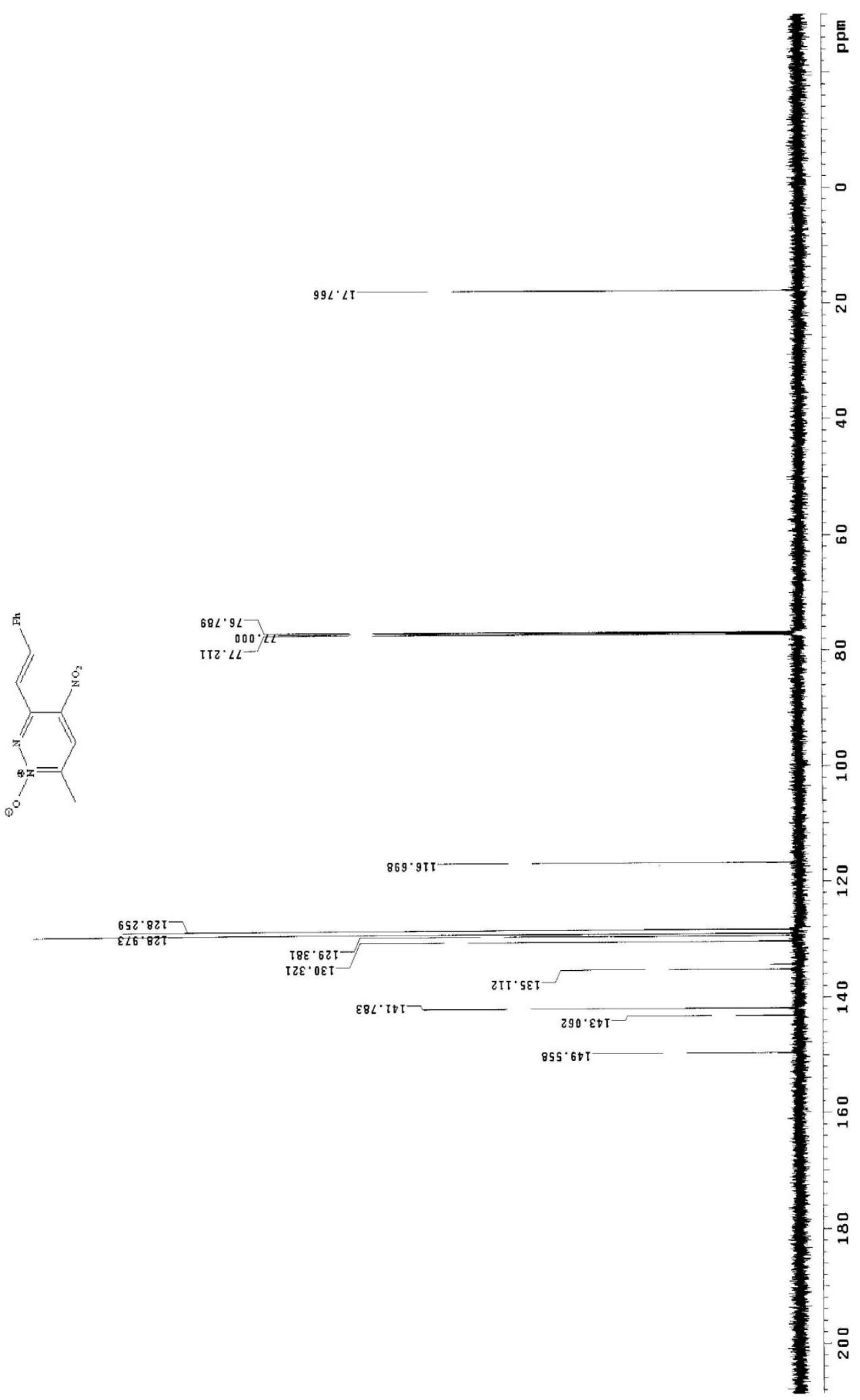


Figure 11: ${ }^{13} \mathrm{C}$ NMR of 6-methyl-4-nitro-3-styrylpyridazine 1-oxide 104

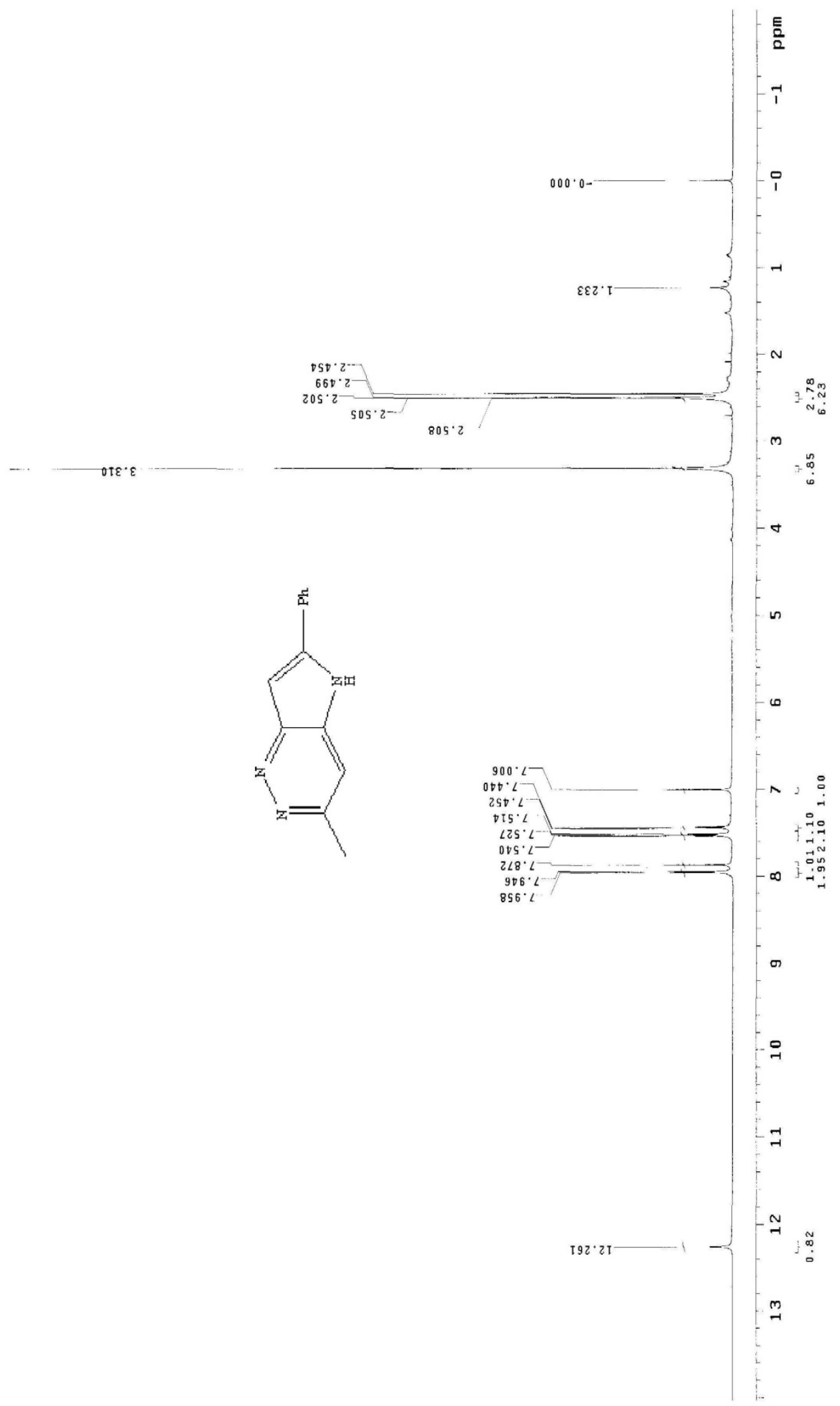


Figure 12: ${ }^{1} \mathrm{H}$ NMR of 6-methyl-2-phenyl-5H-pyrrolo[3,2-c]pyridazine 105

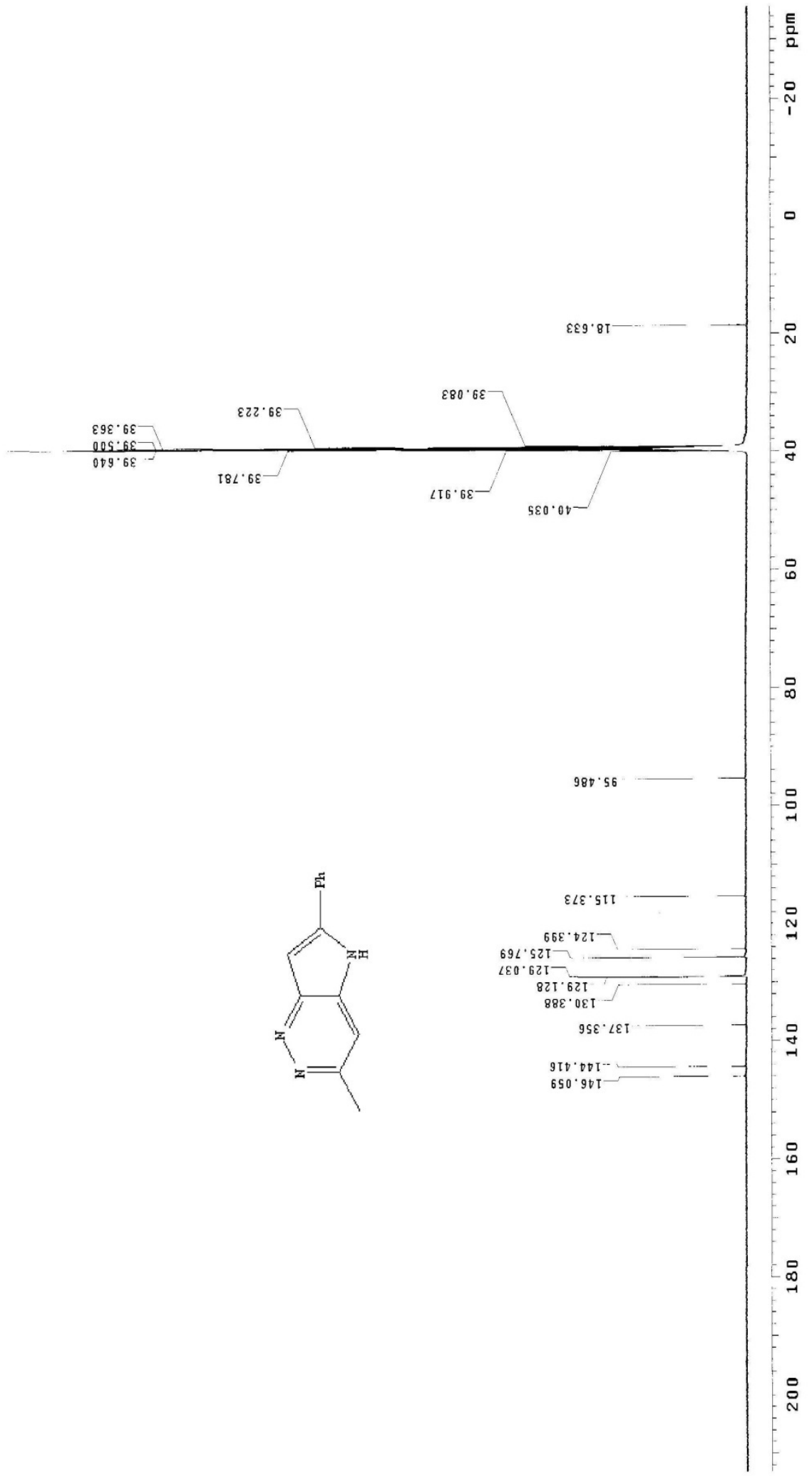


Figure 13: ${ }^{13} \mathrm{C}$ NMR of 6-methyl-2-phenyl-5H-pyrrolo[3,2-c]pyridazine 105

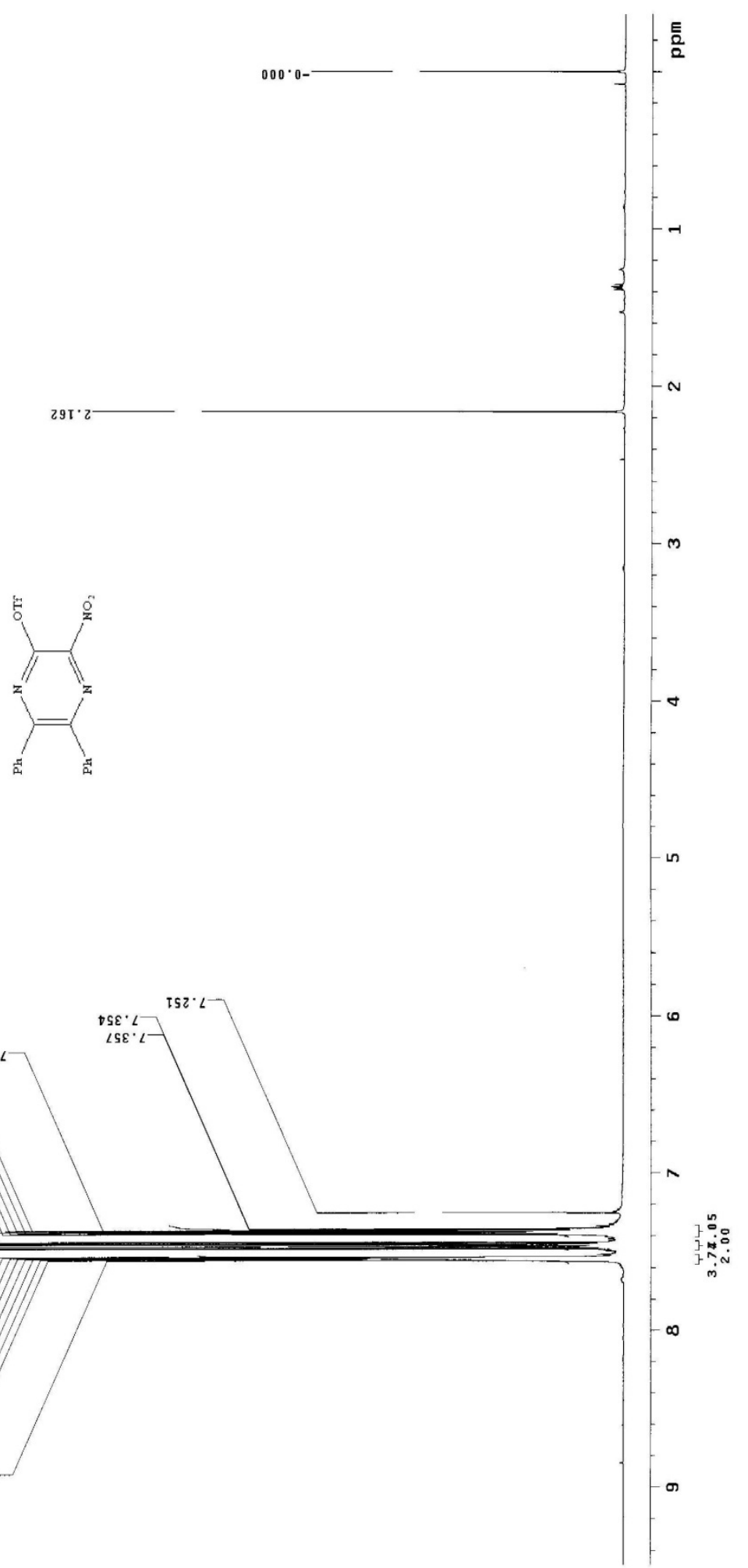

Figure 14: ${ }^{1} \mathrm{H}$ NMR of 2-triflate-3-nitro-5,6-diphenylpyrazine 112 

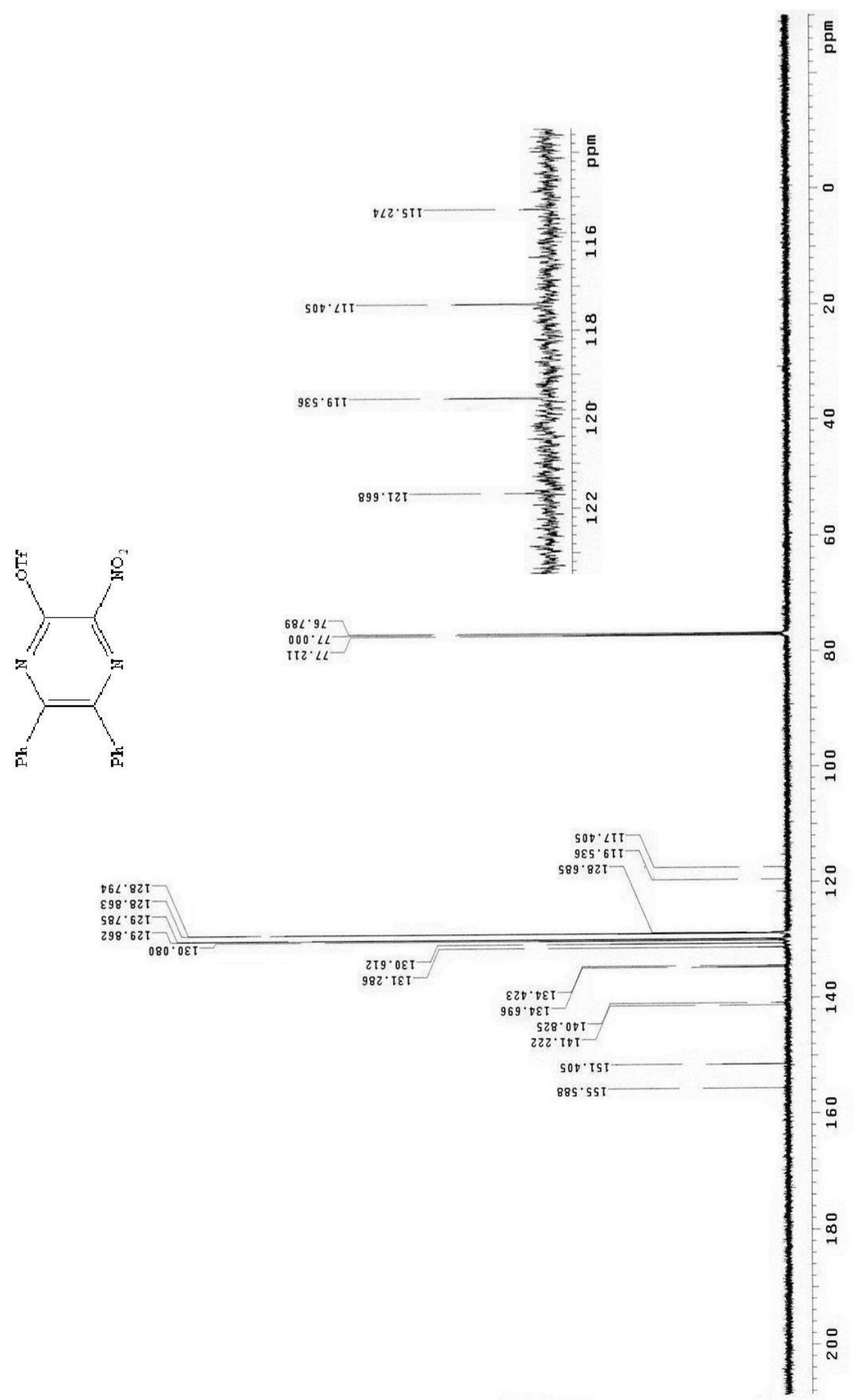

Figure 15: ${ }^{13} \mathrm{C}$ NMR of 2-triflate-3-nitro-5,6-diphenylpyrazine 112 


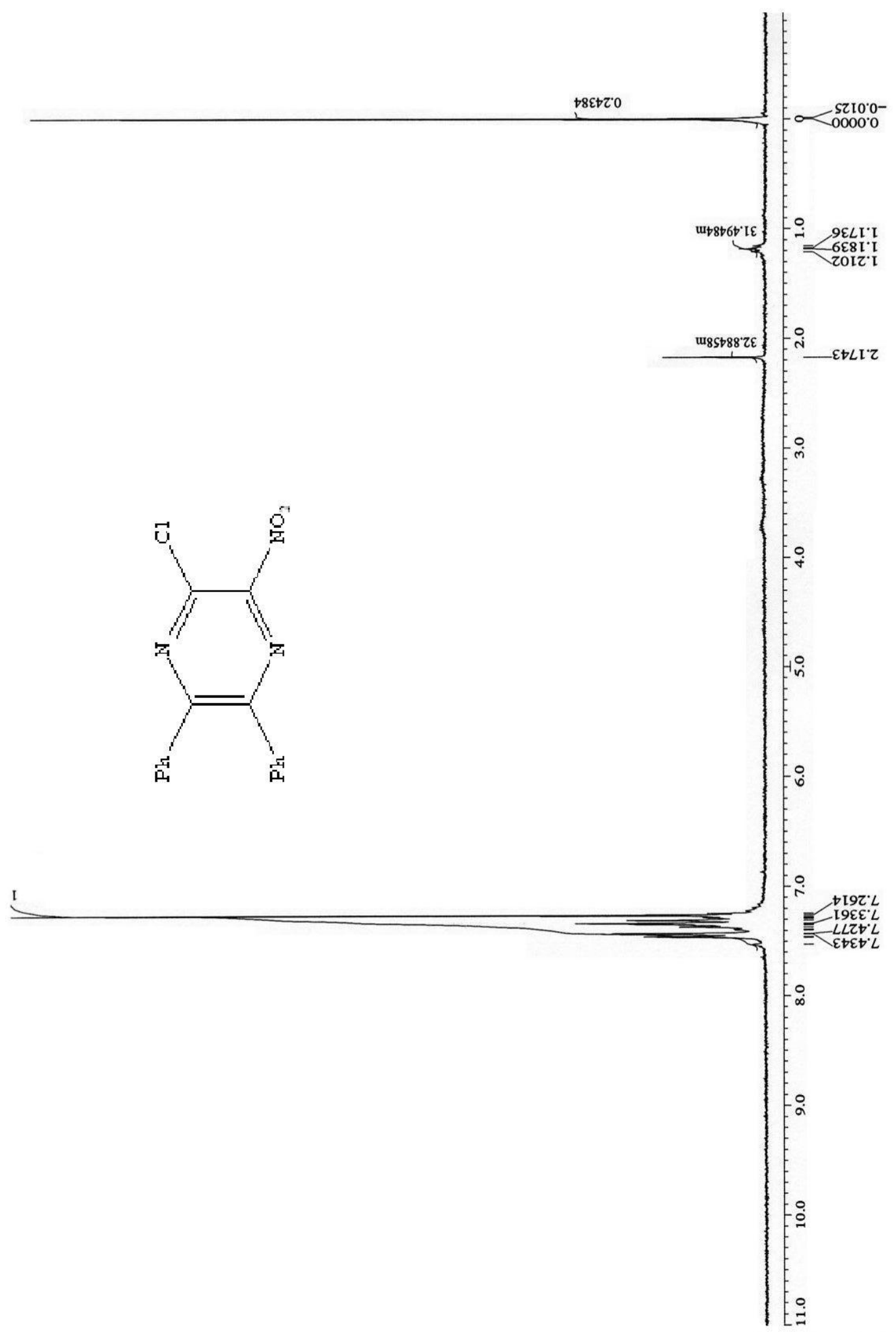

Figure 16: ${ }^{1} \mathrm{H}$ NMR of 2-chloro-3-nitro-5,6-diphenylpyrazine 113

Digitally signed by John $\mathrm{H}$. Hagen DN: cn=John H. Hagen, o=West 